\title{
Synthesis of 1,2,4-oxadiazoles by tandem reaction of nitroalkenes with arenes and nitriles in the superacidTfOH
}

\author{
Andrei A. Golushko, ${ }^{1}$ Olesya V. Khoroshilova, ${ }^{2}$ Aleksander V. Vasilyev ${ }^{1,3 *}$ \\ ${ }^{1}$ Department of Organic Chemistry, Institute of Chemistry, Saint Petersburg State University, \\ Universitetskaya nab., 7/9, Saint Petersburg, 199034, Russia \\ ${ }^{2}$ Center for X-ray Diffraction Studies, Research Park, St. Petersburg State University, \\ Universitetskiy pr., 26, Saint Petersburg, Petrodvoretz, 198504, Russia \\ ${ }^{3}$ Department of Chemistry, Saint Petersburg State Forest Technical University, Institutsky per., \\ 5, Saint Petersburg, 194021, Russia \\ *Corresponding author: A.V. Vasilyev; e-mail: aleksvasil@mail.ru, a.vasilyev@spbu.ru
}

\section{Contents}

1. Copies of ${ }^{1} \mathrm{H},{ }^{13} \mathrm{C},{ }^{19} \mathrm{~F}$ NMR, and IR Spectra of compounds2 S2

2. X-raydata for compounds $\mathbf{2} \mathbf{i}, \mathbf{n}, \mathbf{0}, \mathbf{x}$ 


\section{Copies of ${ }^{1} \mathrm{H},{ }^{13} \mathrm{C},{ }^{19} \mathrm{~F}$ NMR, and IR spectra of compounds2}

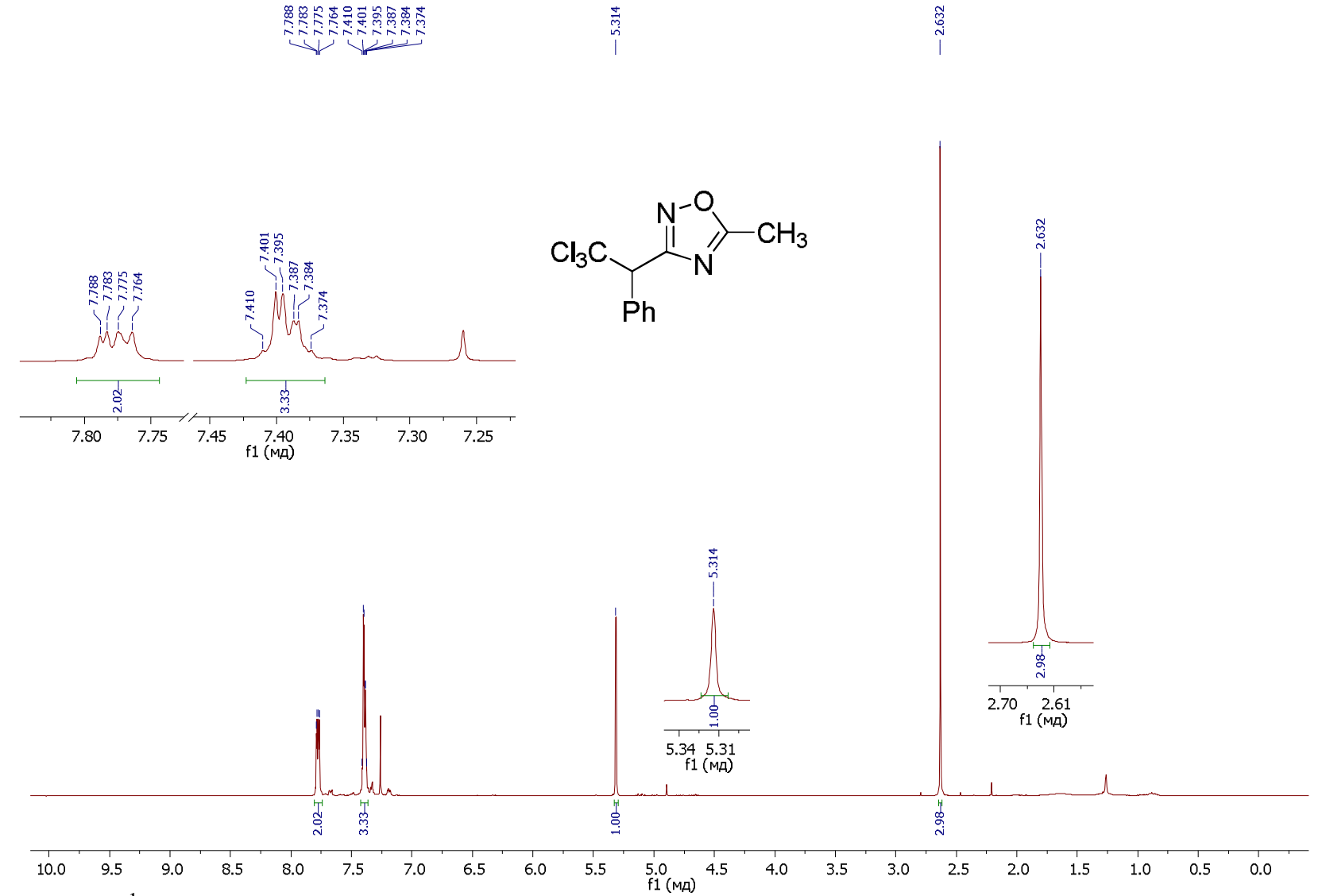

Fig. S1. ${ }^{1} \mathrm{H}$ NMR spectrum of the compound $2 \mathbf{a}\left(\mathrm{CDCl}_{3}, 400 \mathrm{MHz}\right)$.

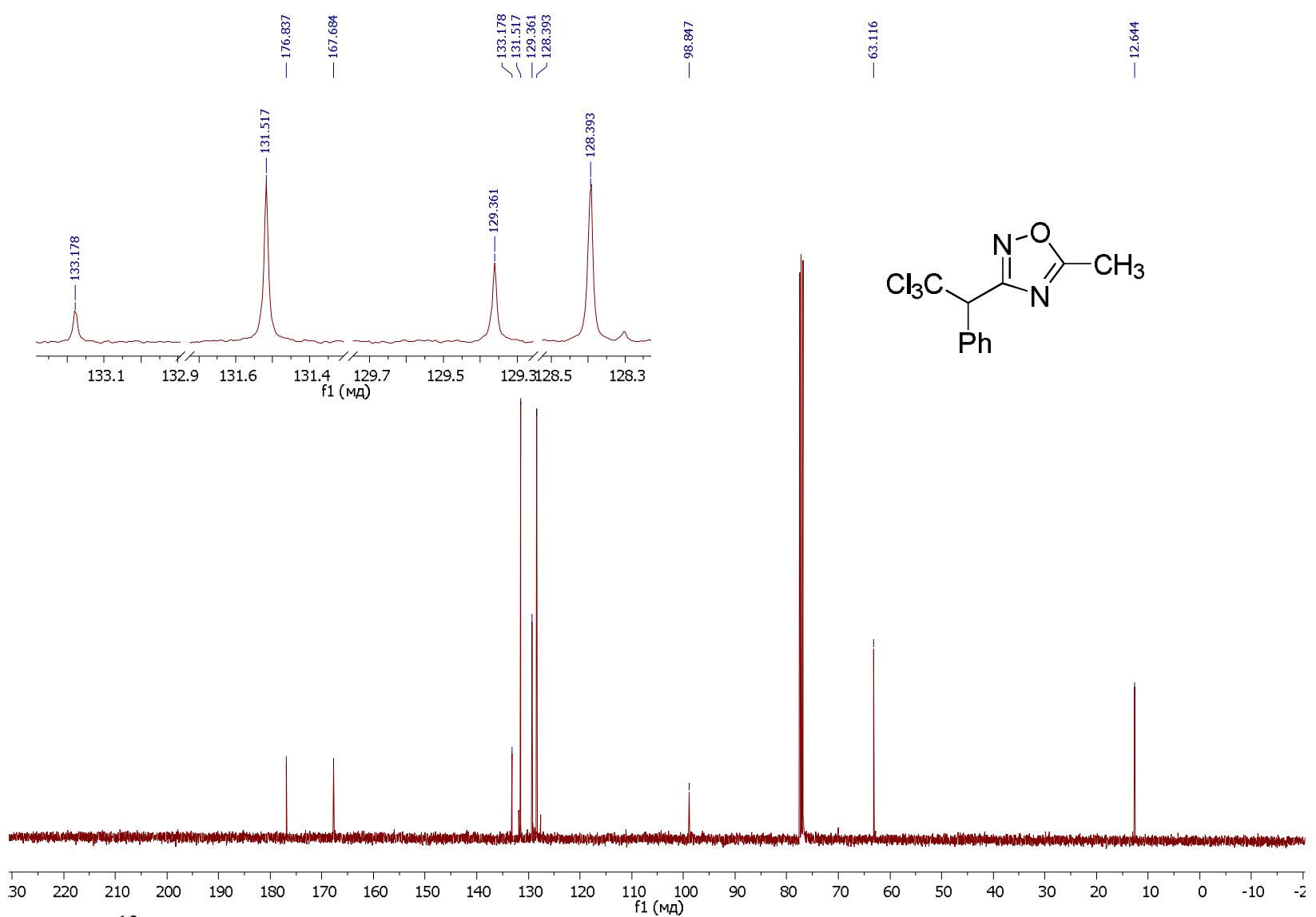

Fig. S2. ${ }^{13} \mathrm{C}\{\mathrm{H}\}$ NMR spectrum of the compound $\mathbf{2 a}\left(\mathrm{CDCl}_{3}, 100 \mathrm{MHz}\right)$. 

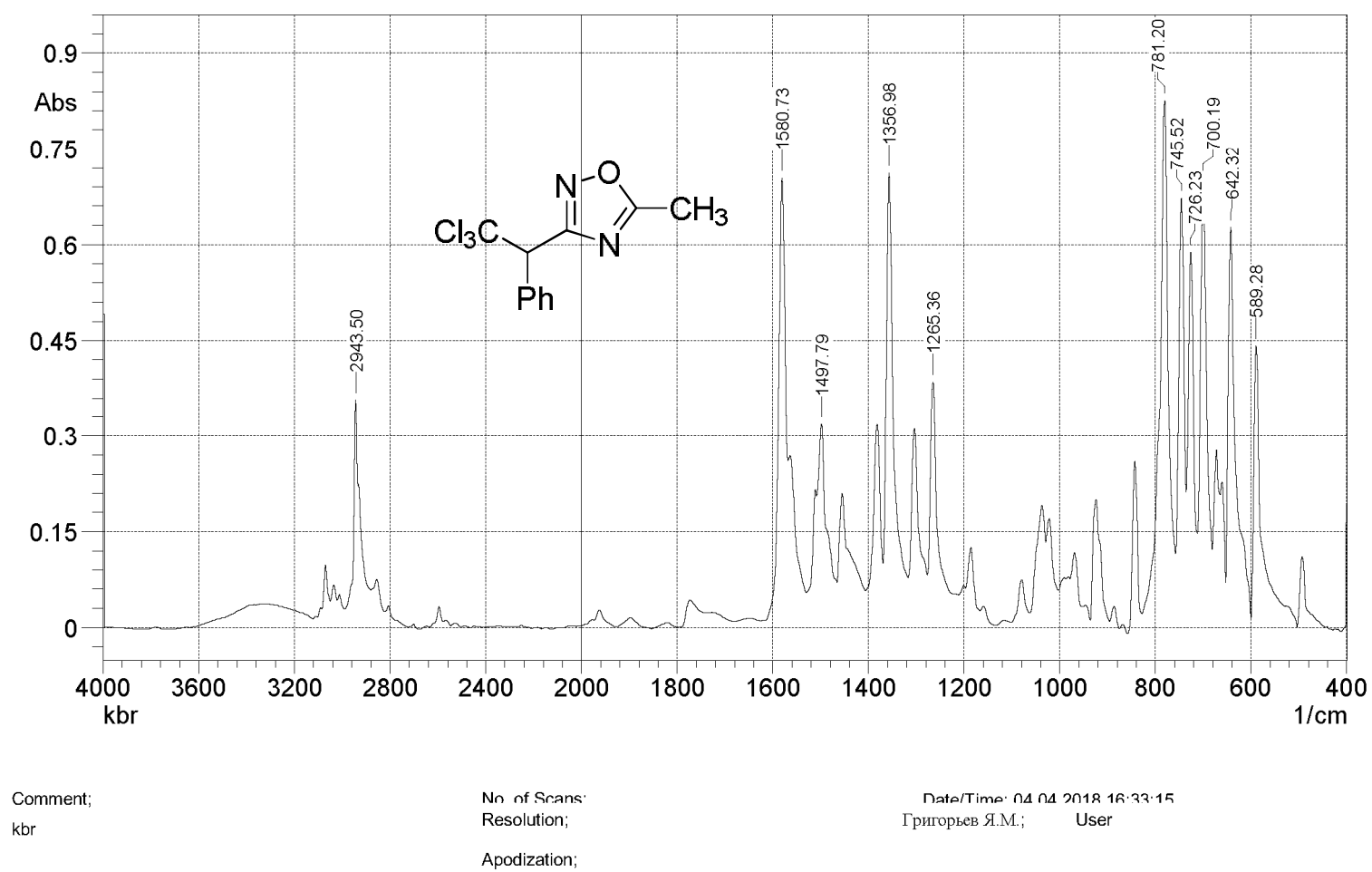

Fig. S3. ${ }^{1} \mathrm{H}$ NMR spectrum of the compound $\mathbf{2 a}\left(\mathrm{CDCl}_{3}, 400 \mathrm{MHz}\right)$.

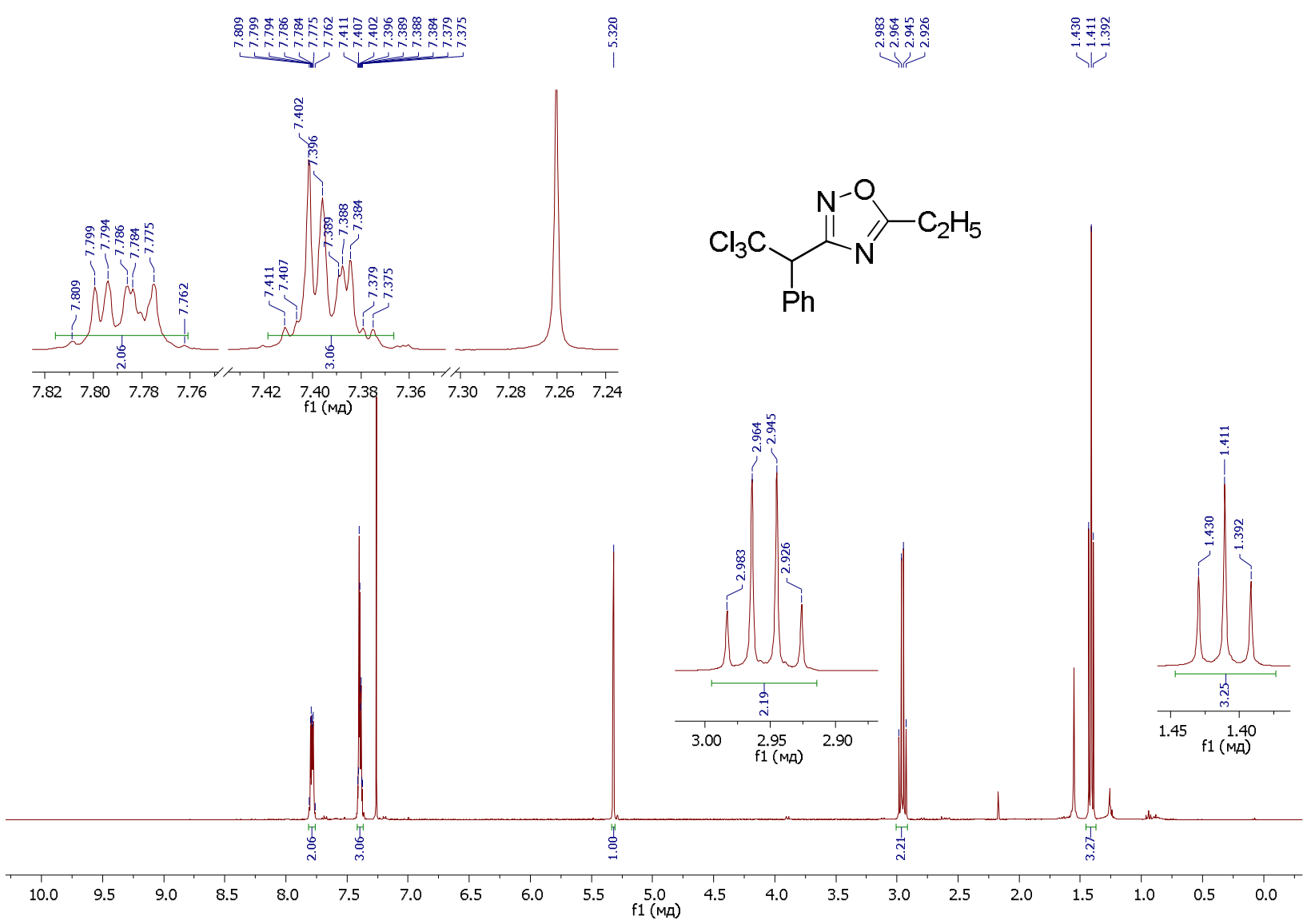

Fig. S4. ${ }^{1} \mathrm{H}$ NMR spectrum of the compound $\mathbf{2 b}\left(\mathrm{CDCl}_{3}, 400 \mathrm{MHz}\right)$. 


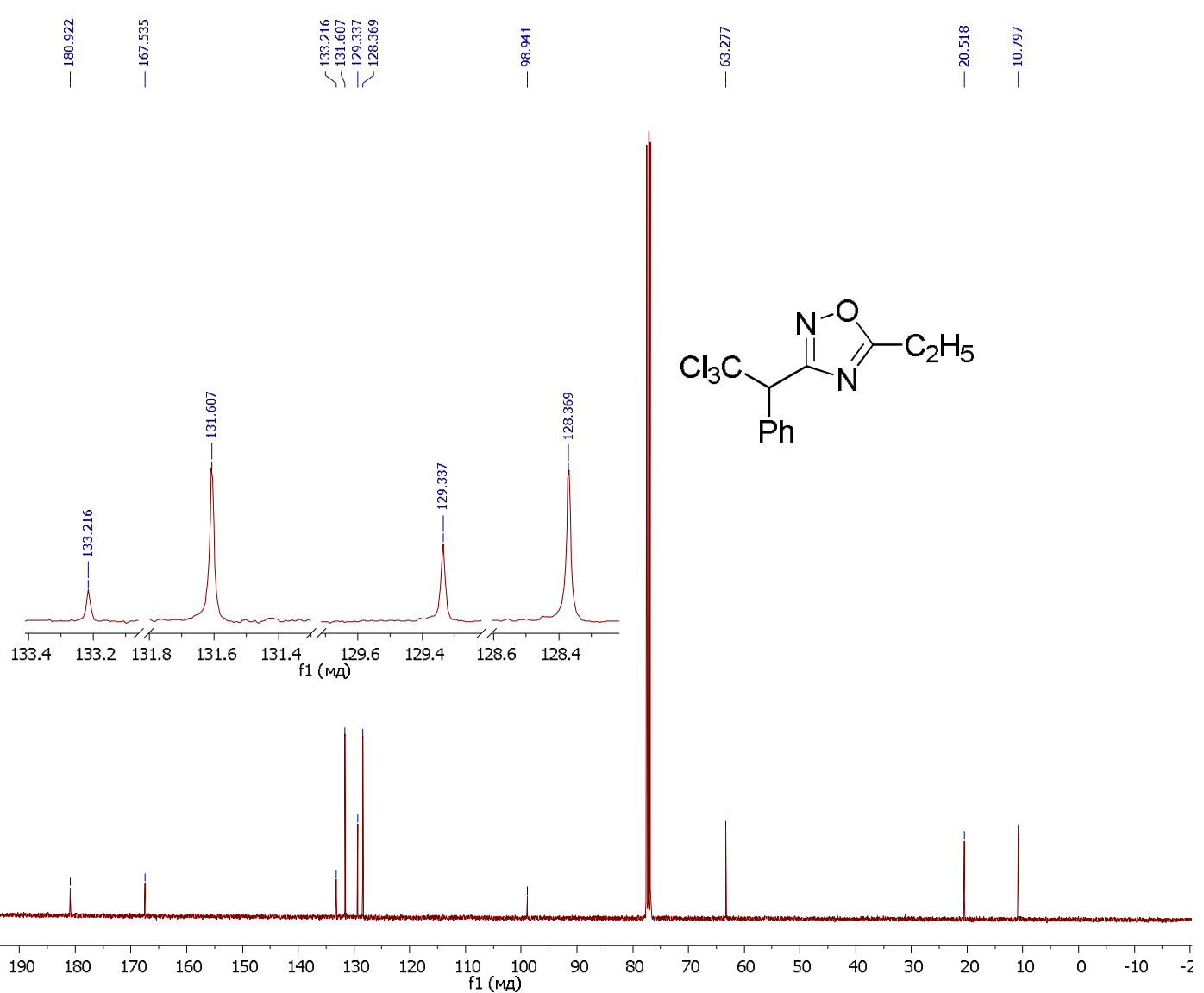

Fig. $\mathrm{S} 5 .{ }^{13} \mathrm{C}\{\mathrm{H}\}$ NMR spectrum of the compound $\mathbf{2 b}\left(\mathrm{CDCl}_{3}, 101 \mathrm{MHz}\right)$.

由SHIMADZu

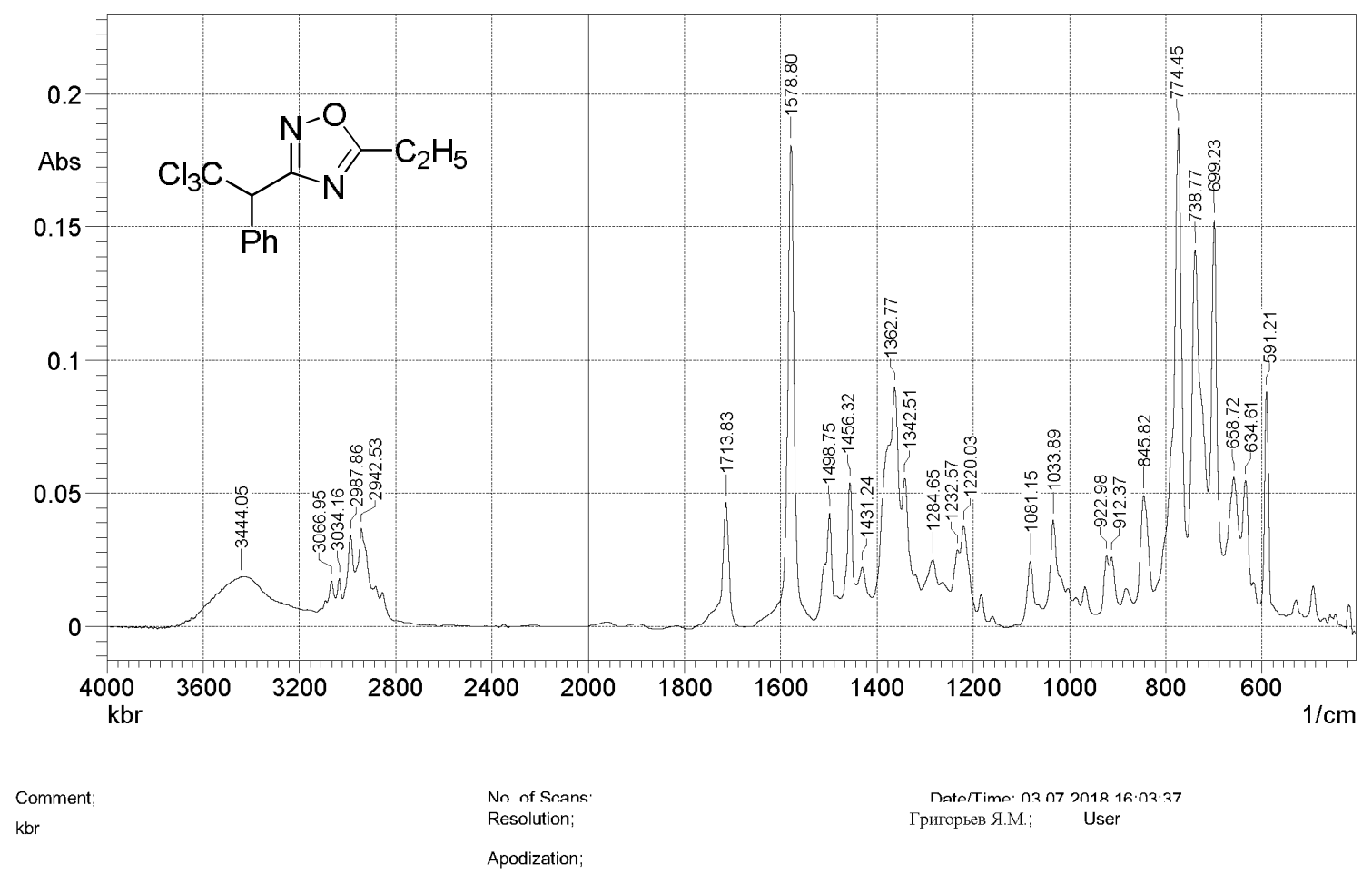

Fig. S6. IR spectrum of the compound $\mathbf{2 b}(\mathrm{KBr})$. 


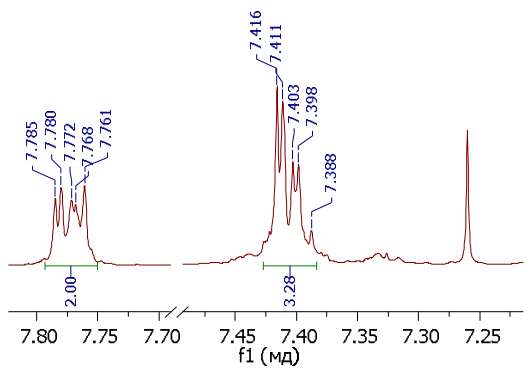<smiles>ClCc1nc(C(c2ccccc2)C(Cl)(Cl)Cl)no1</smiles>

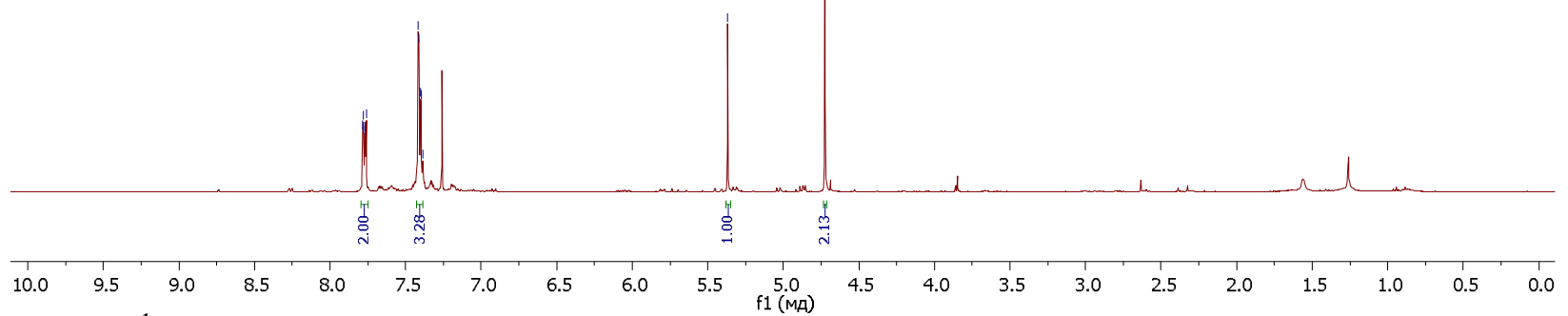

Fig. S7. ${ }^{1} \mathrm{H}$ NMR spectrum of the compound $2 \mathbf{c}\left(\mathrm{CDCl}_{3}, 400 \mathrm{MHz}\right)$.

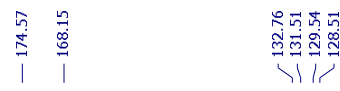

$$
\underset{\substack{\infty \\ \infty \\ \infty}}{\infty}
$$
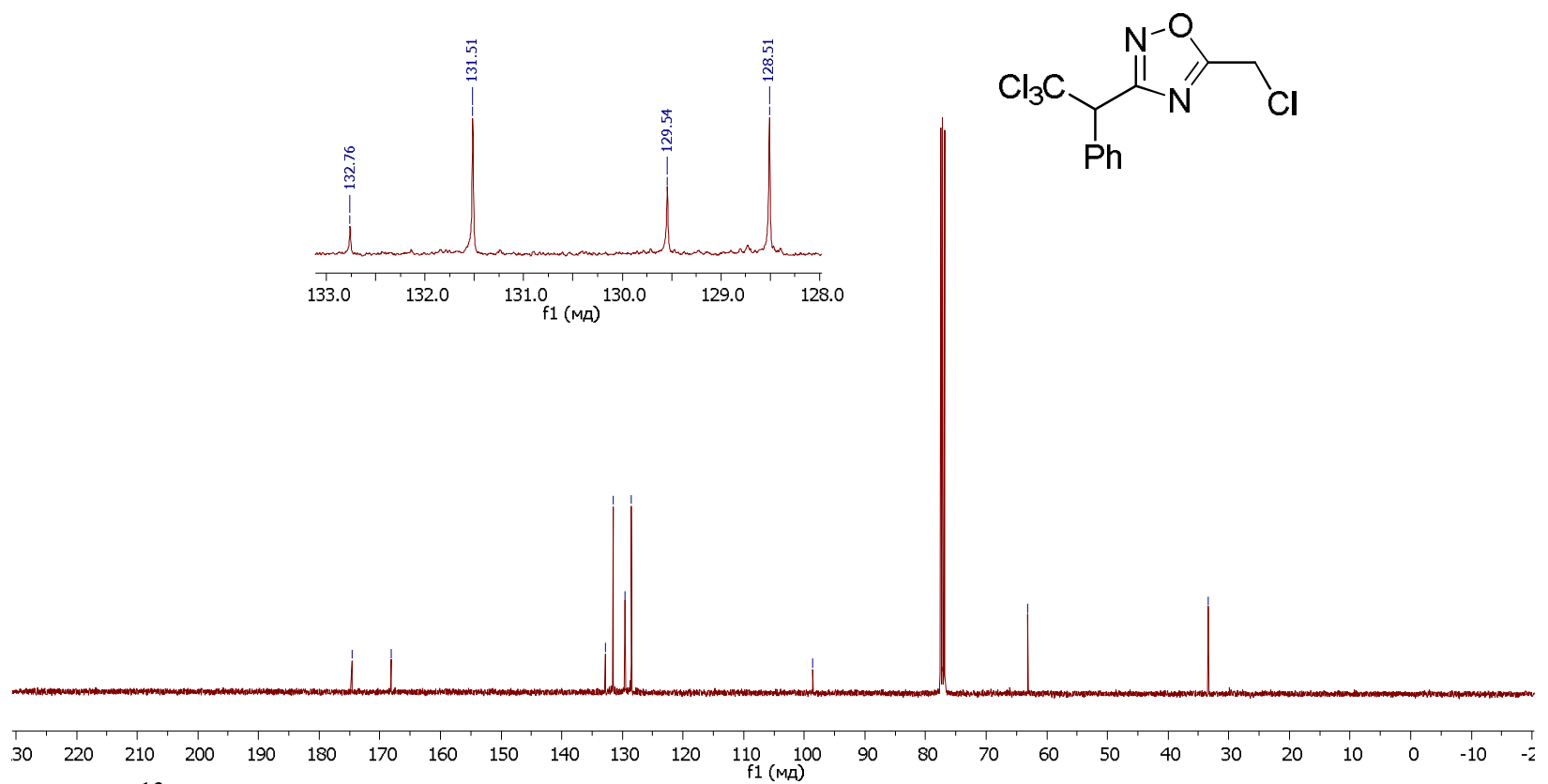

Fig. S8. ${ }^{13} \mathrm{C}\{\mathrm{H}\}$ NMR spectrum of the compound $\mathbf{2 c}\left(\mathrm{CDCl}_{3}, 101 \mathrm{MHz}\right)$. 


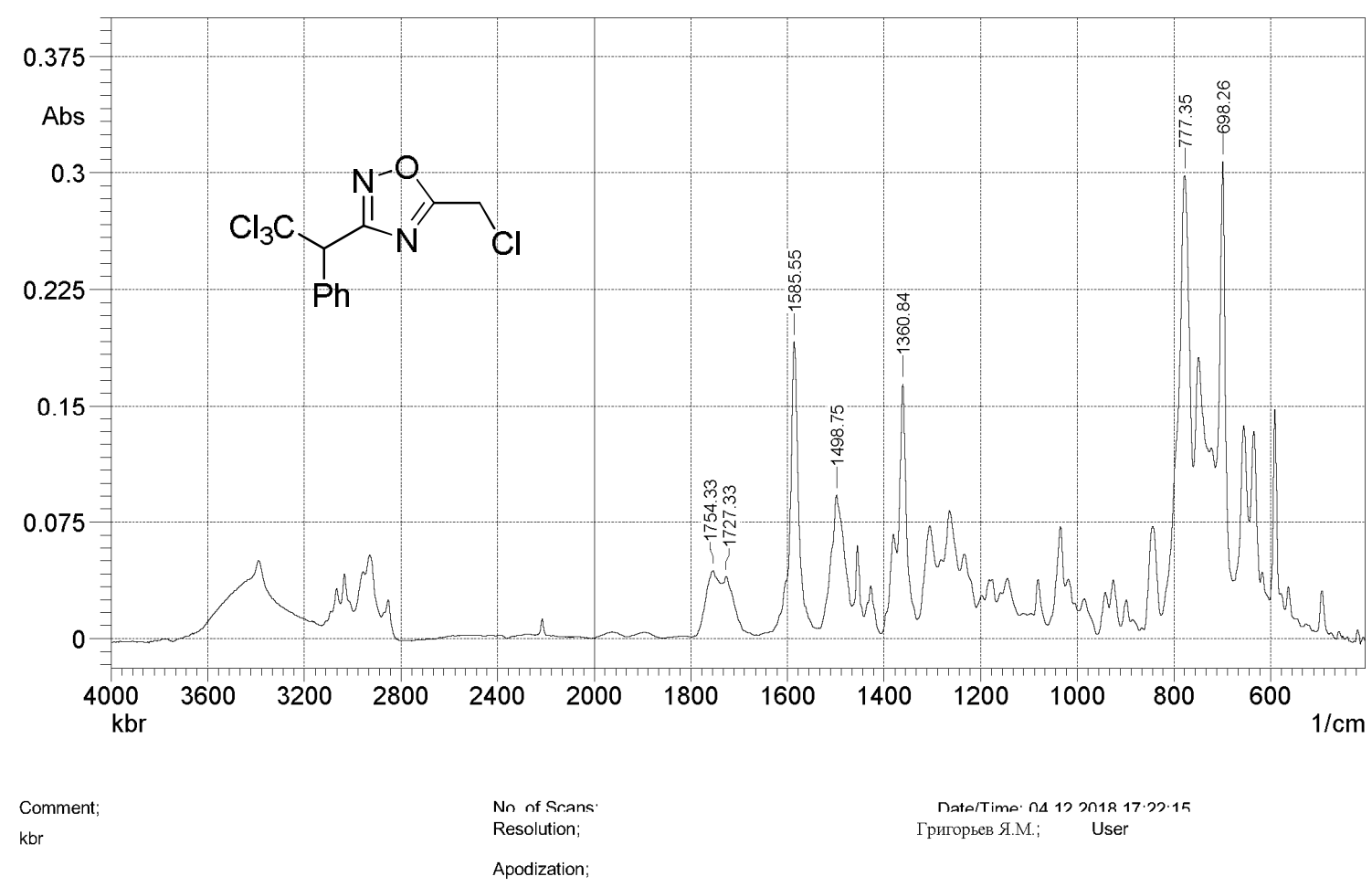

Fig. S9. IR spectrum of the compound $\mathbf{2 c}(\mathrm{KBr})$.
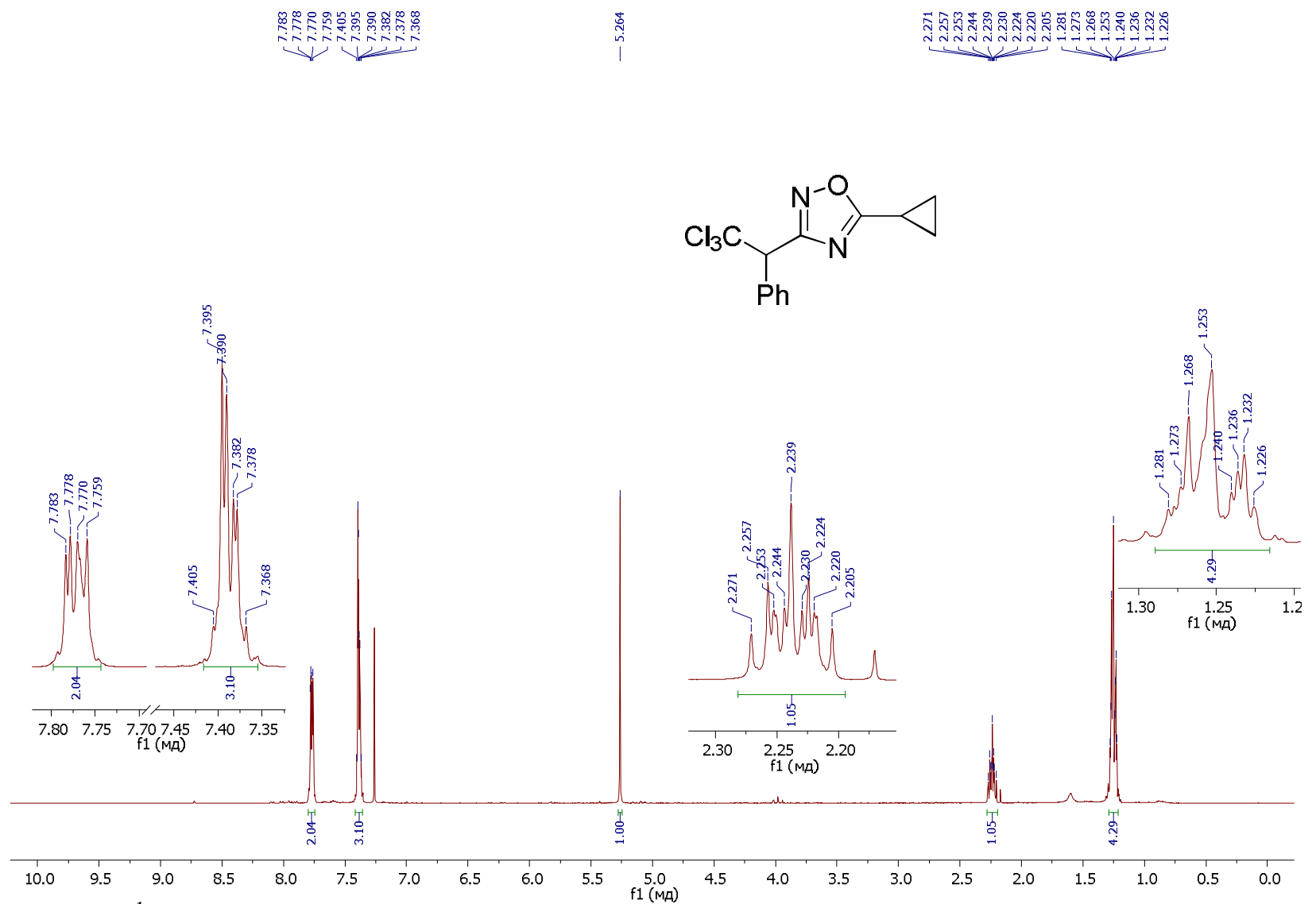

Fig. S10. ${ }^{1} \mathrm{H}$ NMR spectrum of the compound $2 \mathbf{d}\left(\mathrm{CDCl}_{3}, 400 \mathrm{MHz}\right)$. 


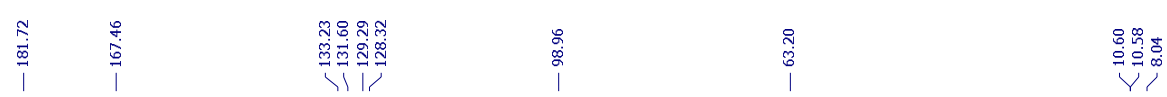

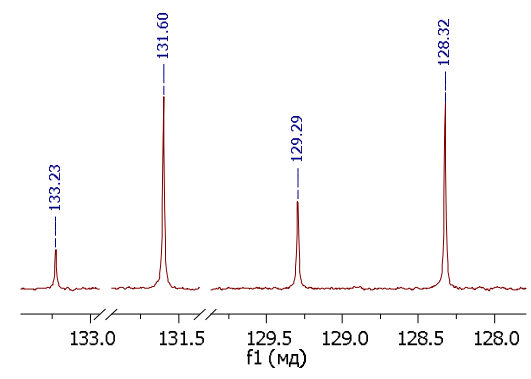<smiles>ClC(Cl)C(c1ccccc1)c1noc(C2CC2)n1</smiles>

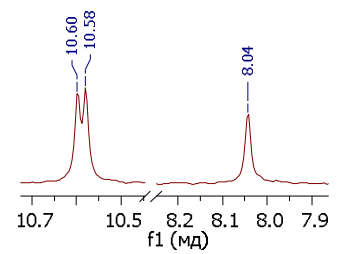

Fig. S11. ${ }^{13} \mathrm{C}\{\mathrm{H}\}$ NMR spectrum of the compound $\mathbf{2 d}\left(\mathrm{CDCl}_{3}, 101 \mathrm{MHz}\right)$.

Ф SHIMADZU

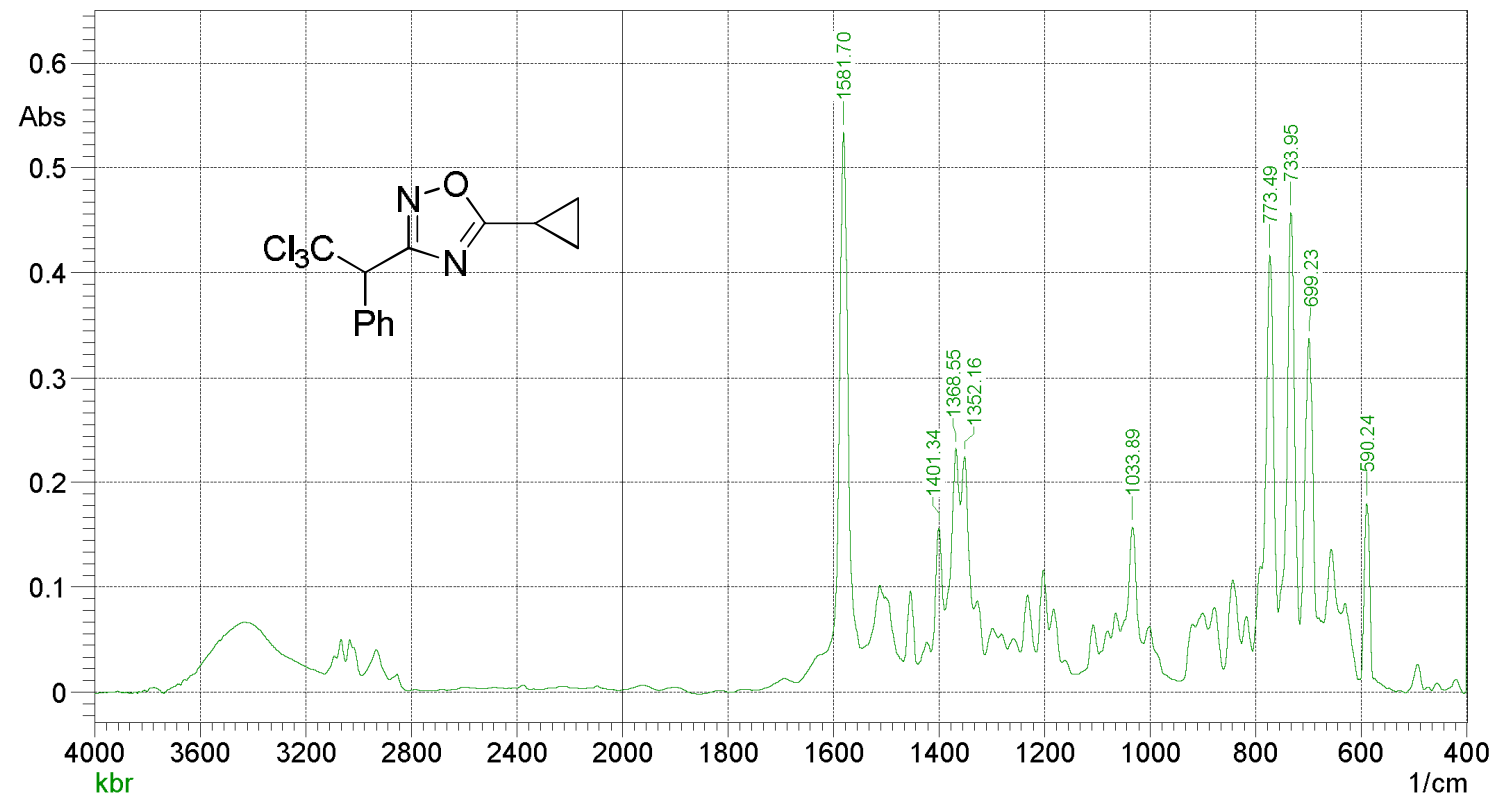

Comment;

$\mathrm{kbr}$
No nf Srans

Resolution;

Apodization
nate/Time. nA 12 2018 17.46.51 Гриторьев Я.M.; User

Fig. S12.IR spectrum of the compound $\mathbf{2 d}(\mathrm{KBr})$. 
<smiles>ClC(Cl)(c1ccccc1)C(c1ccccc1)c1noc(-c2ccccc2)n1</smiles>

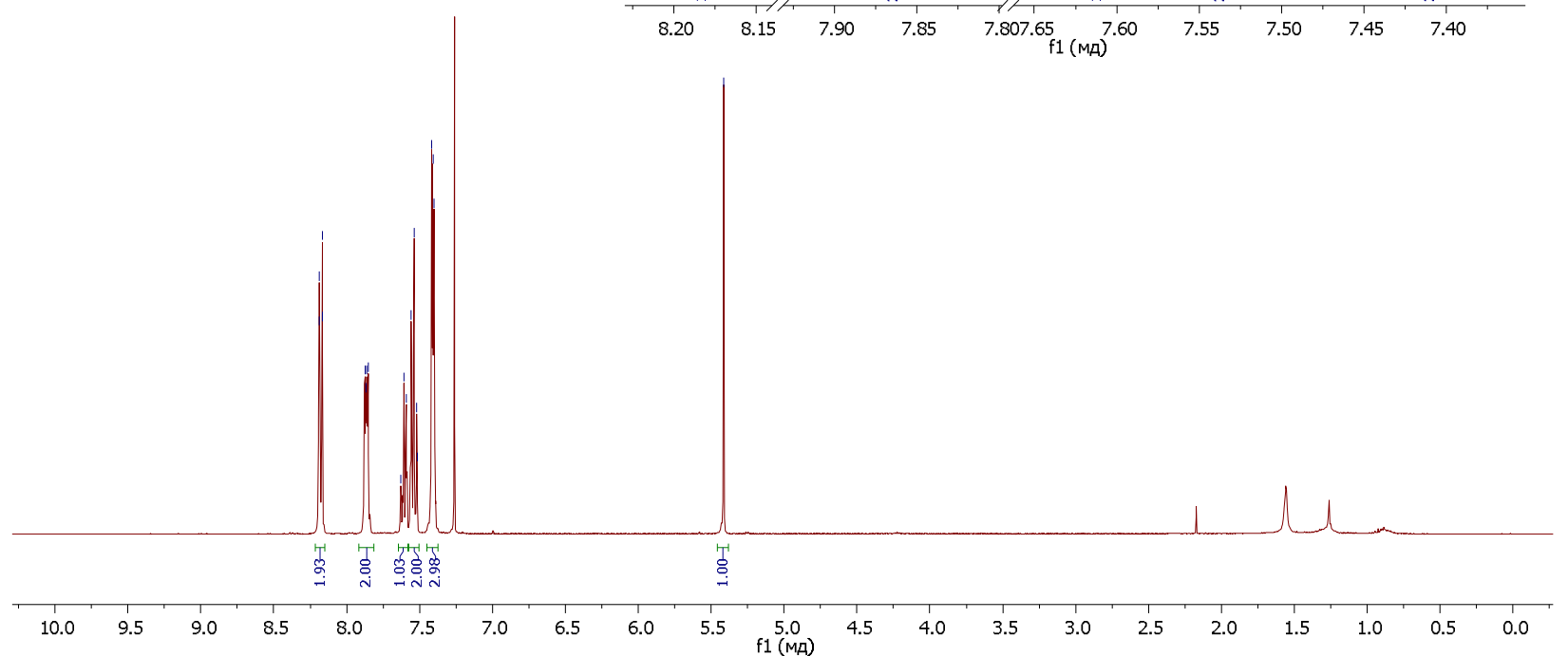

Fig. S13. ${ }^{1} \mathrm{H}$ NMR spectrum of the compound $2 \mathrm{e}\left(\mathrm{CDCl}_{3}, 400 \mathrm{MHz}\right)$.

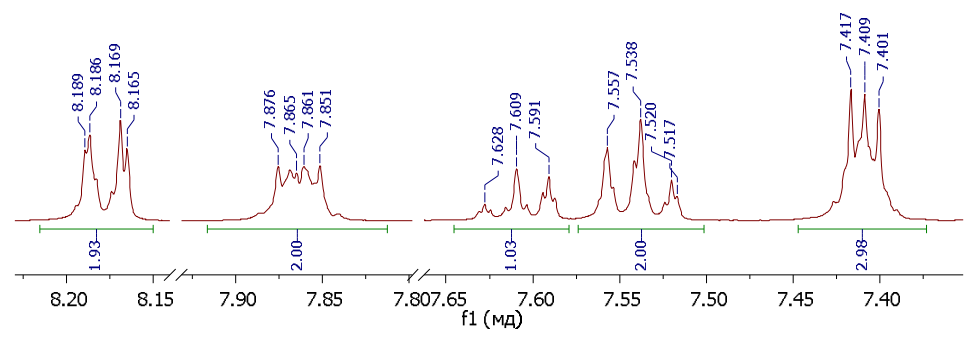

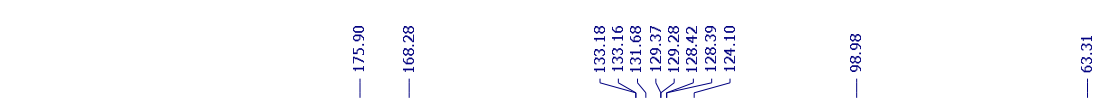
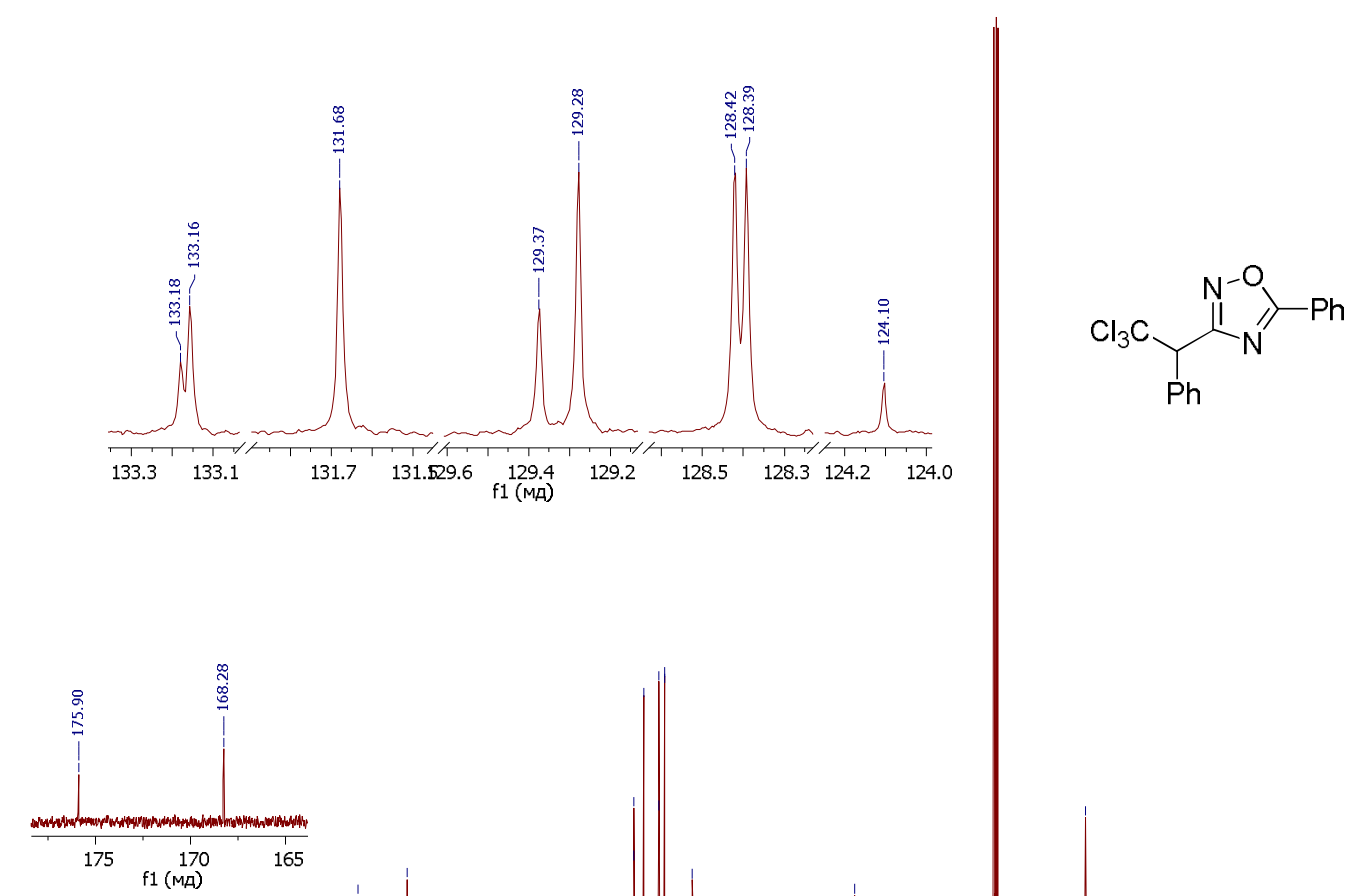

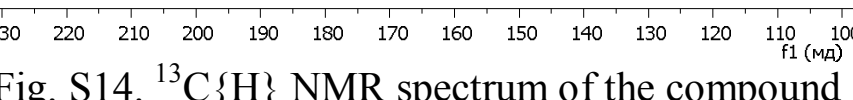

Fig. S14. ${ }^{13} \mathrm{C}\{\mathrm{H}\}$ NMR spectrum of the compound $2 \mathrm{e}\left(\mathrm{CDCl}_{3}, 101 \mathrm{MHz}\right)$. 


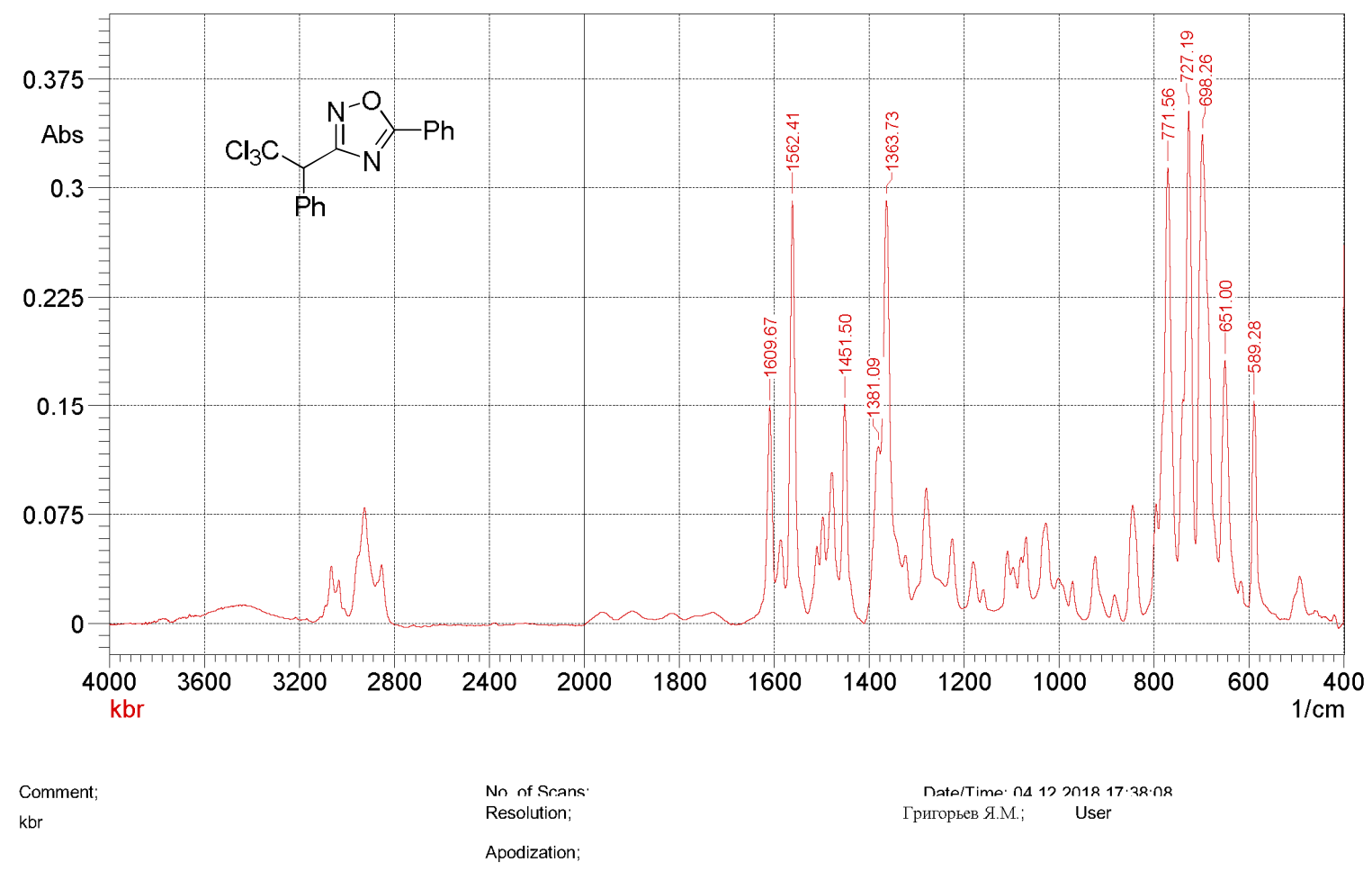

Fig. S15. IR spectrum of the compound $2 \mathbf{e}(\mathrm{KBr})$.
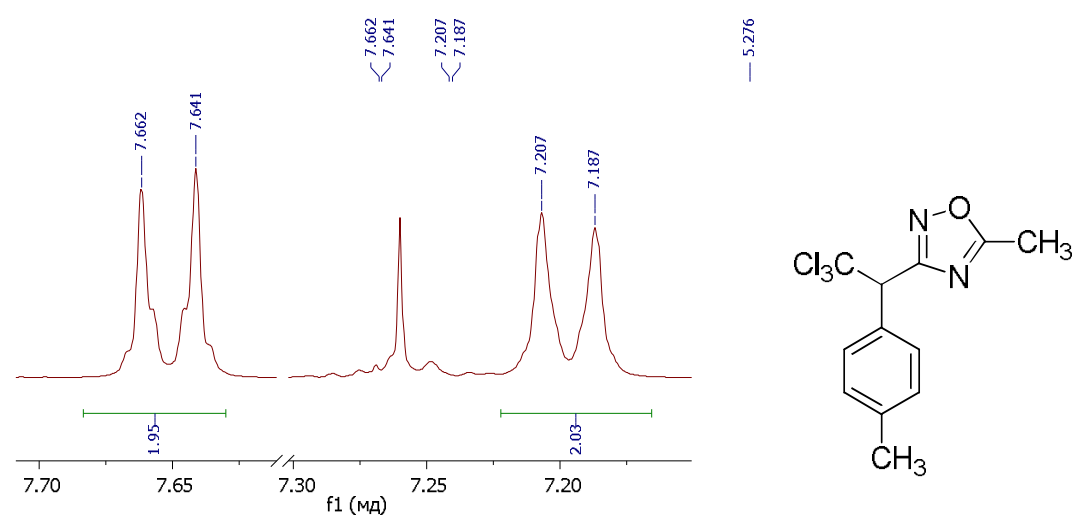

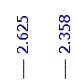

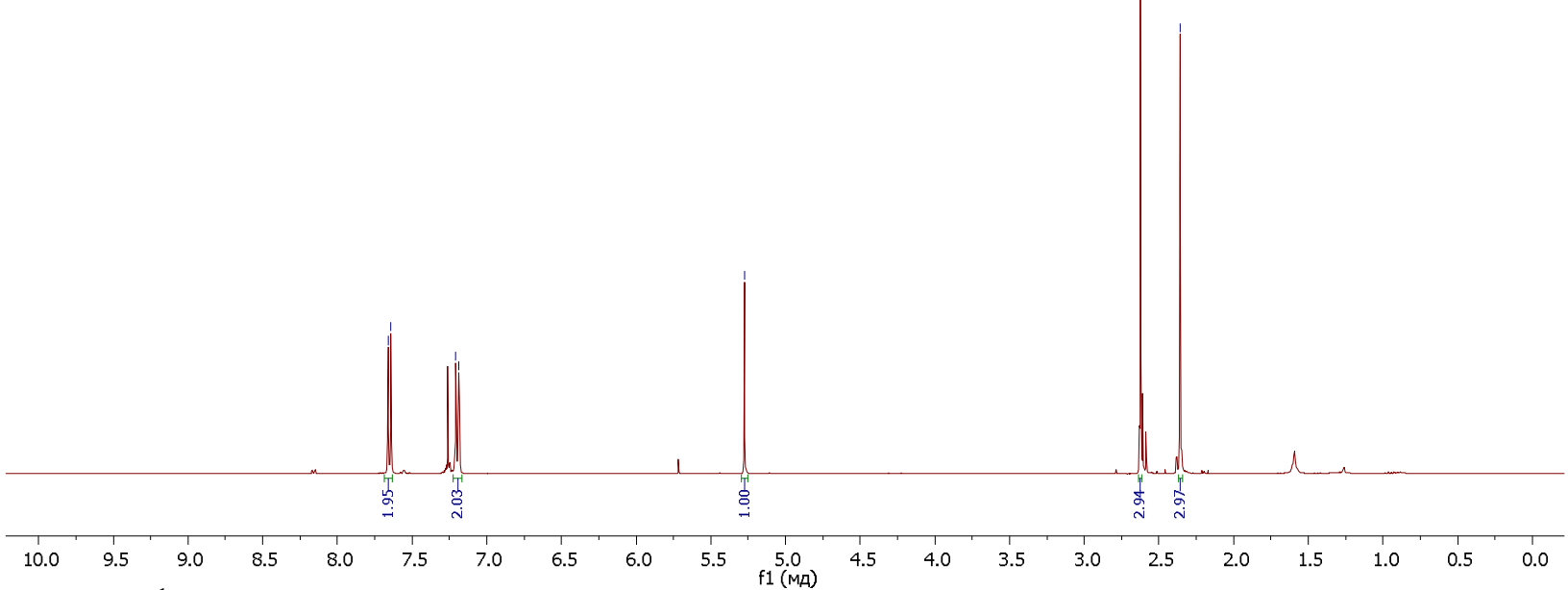

Fig. S16. ${ }^{1} \mathrm{H}$ NMR spectrum of the compound $\mathbf{2 f}\left(\mathrm{CDCl}_{3}, 400 \mathrm{MHz}\right)$. 


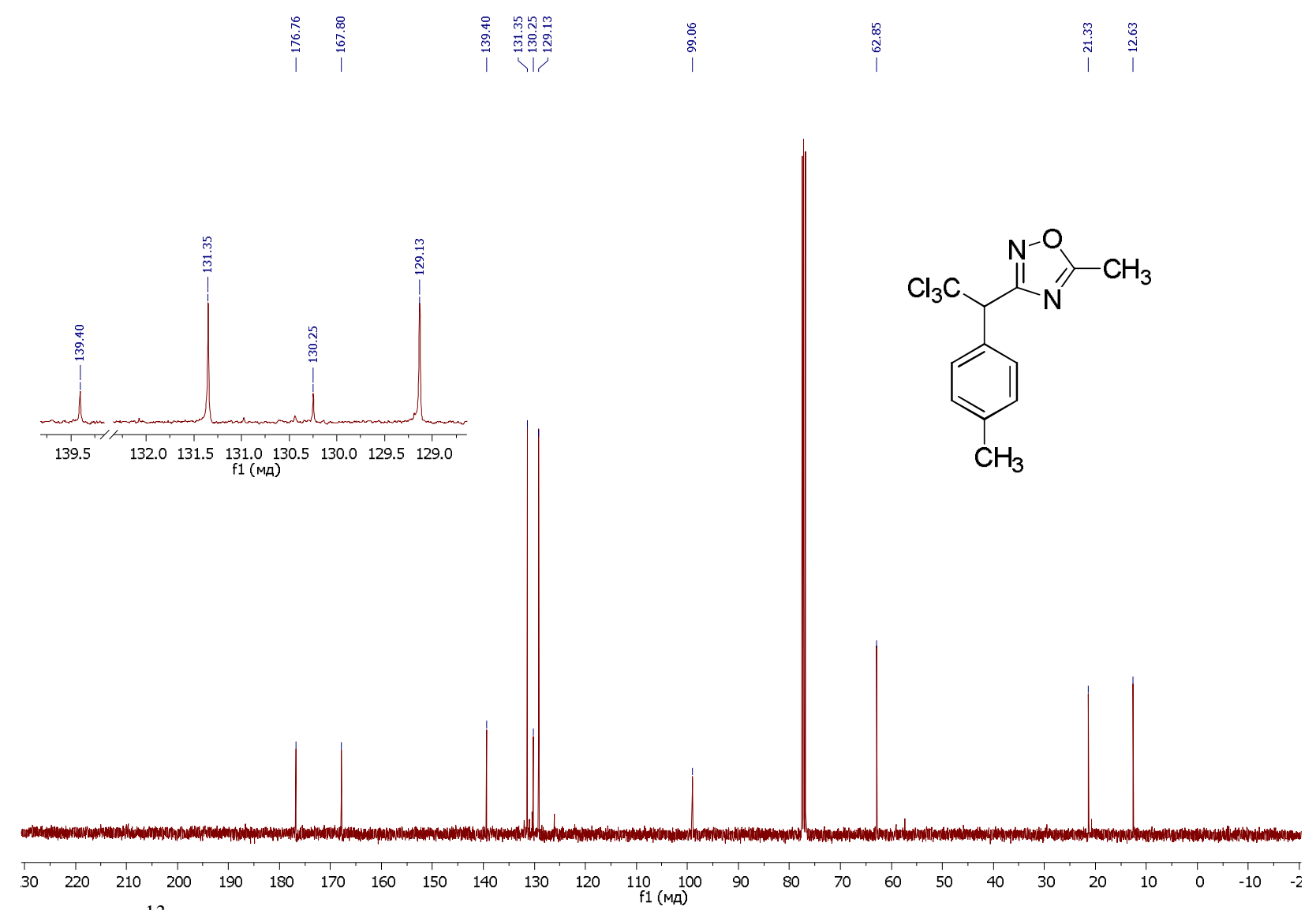

Fig. S17. ${ }^{13} \mathrm{C}\{\mathrm{H}\}$ NMR spectrum of the compound $2 \mathbf{f}\left(\mathrm{CDCl}_{3}, 101 \mathrm{MHz}\right)$.

ФSHIMADZu

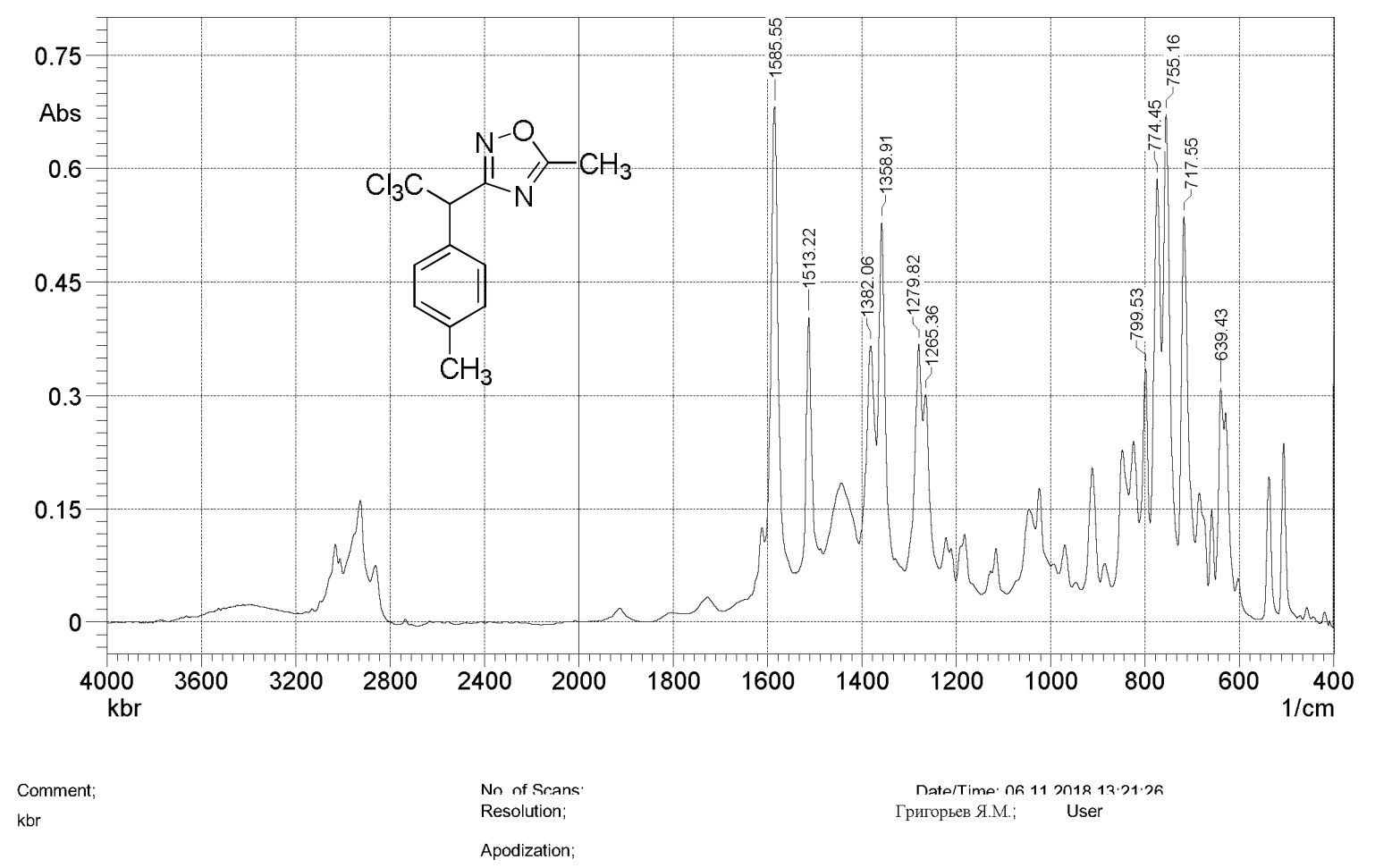

Fig. S18. IR spectrum of the compound $\mathbf{2 f}(\mathrm{KBr})$. 


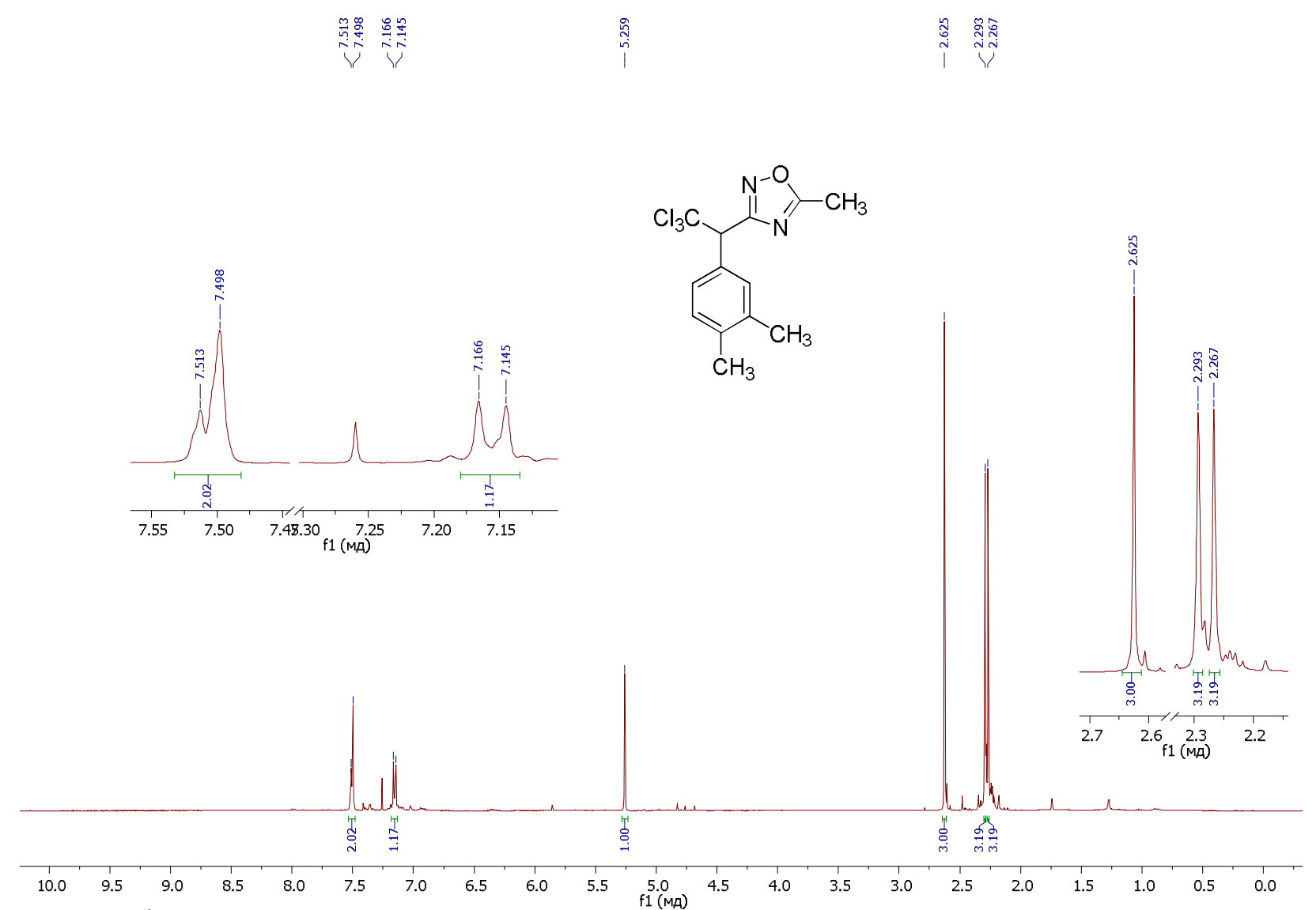

Fig. S19. ${ }^{1} \mathrm{H}$ NMR spectrum of the compound $2 \mathrm{~g}\left(\mathrm{CDCl}_{3}, 400 \mathrm{MHz}\right)$.

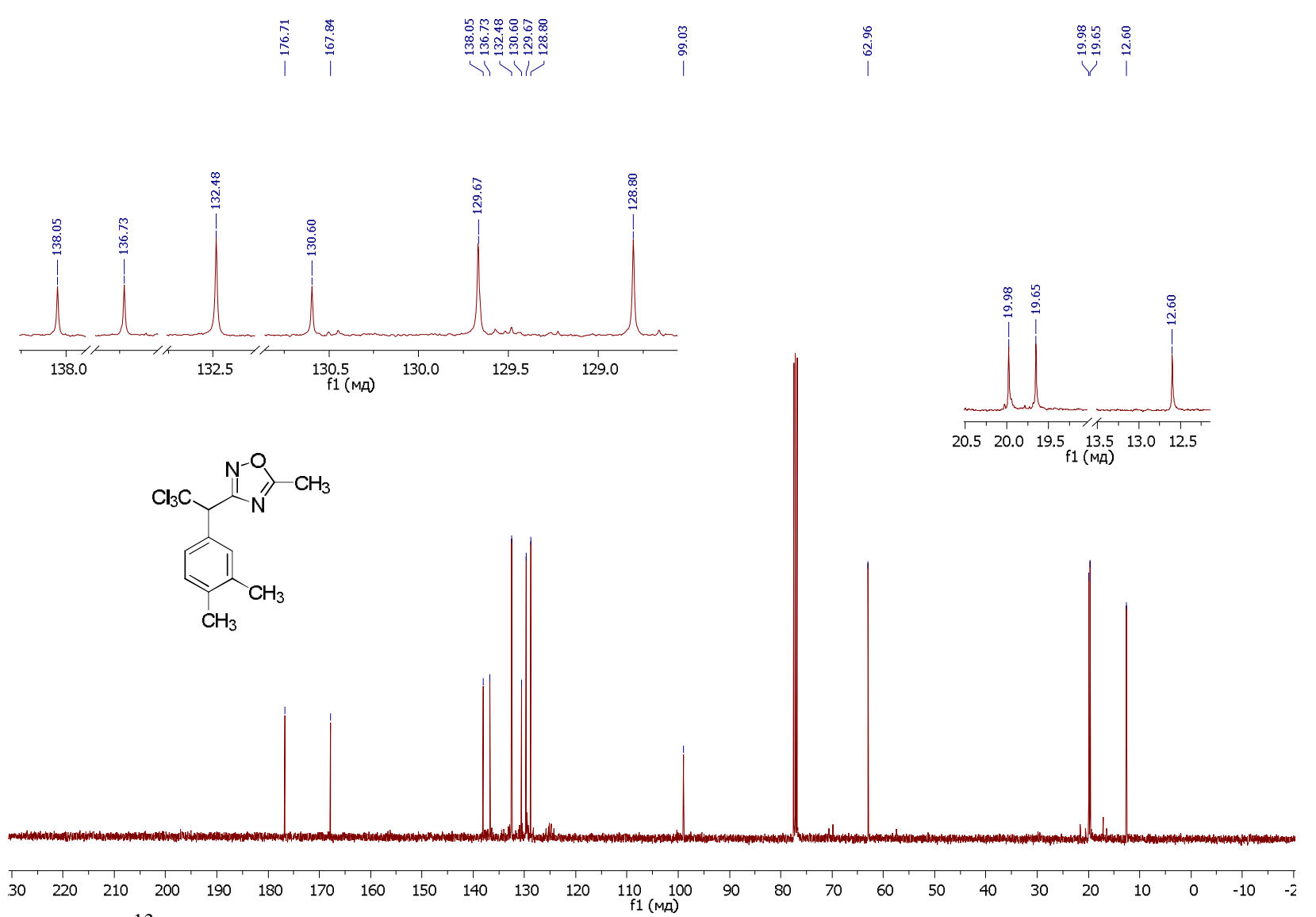

Fig. S20. ${ }^{13} \mathrm{C}\{\mathrm{H}\}$ NMR spectrum of the compound $\mathbf{2 g}\left(\mathrm{CDCl}_{3}, 101 \mathrm{MHz}\right)$. 

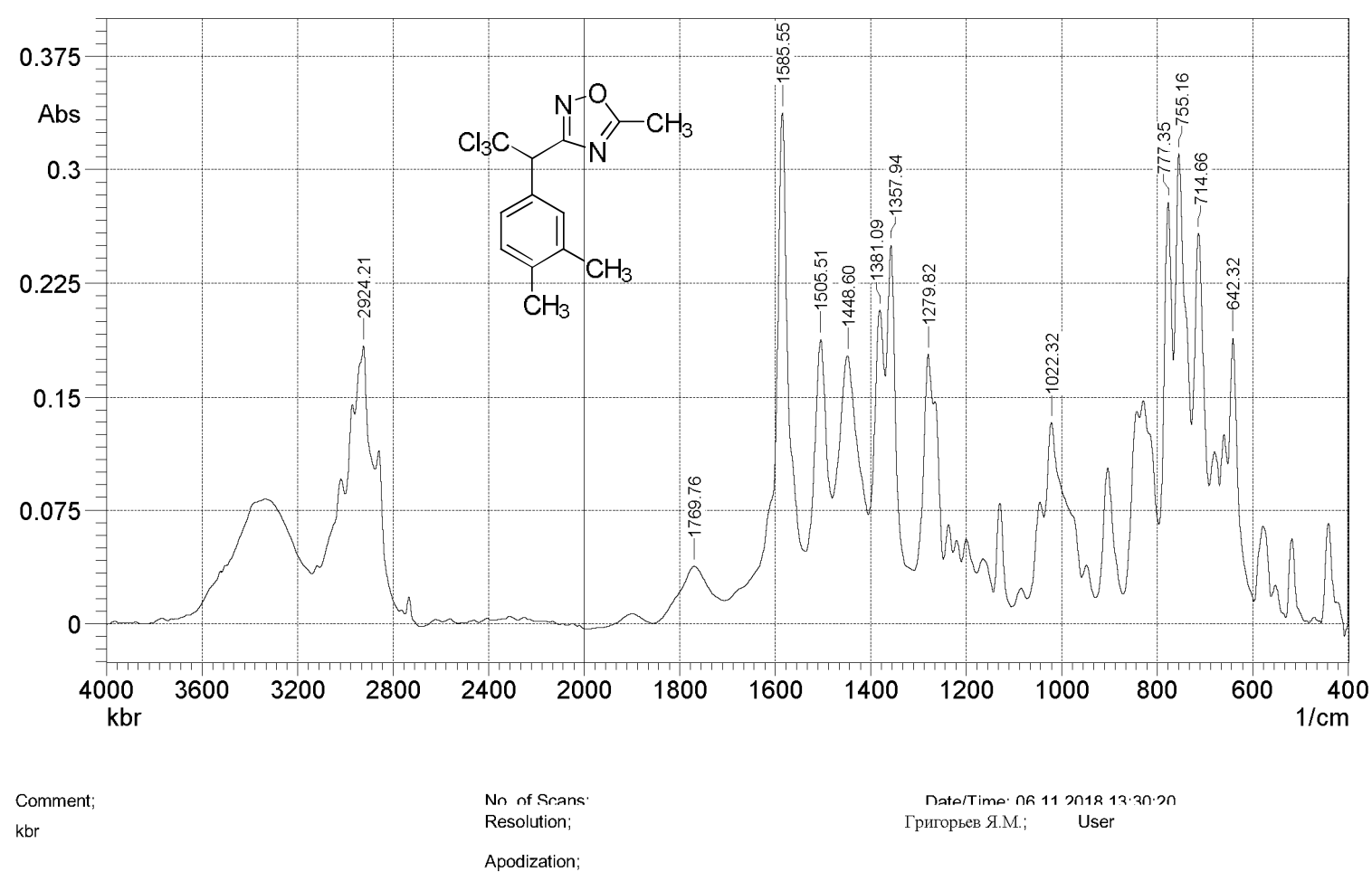

Fig. S21. IR spectrum of the compound $\mathbf{2 g}(\mathrm{KBr})$.
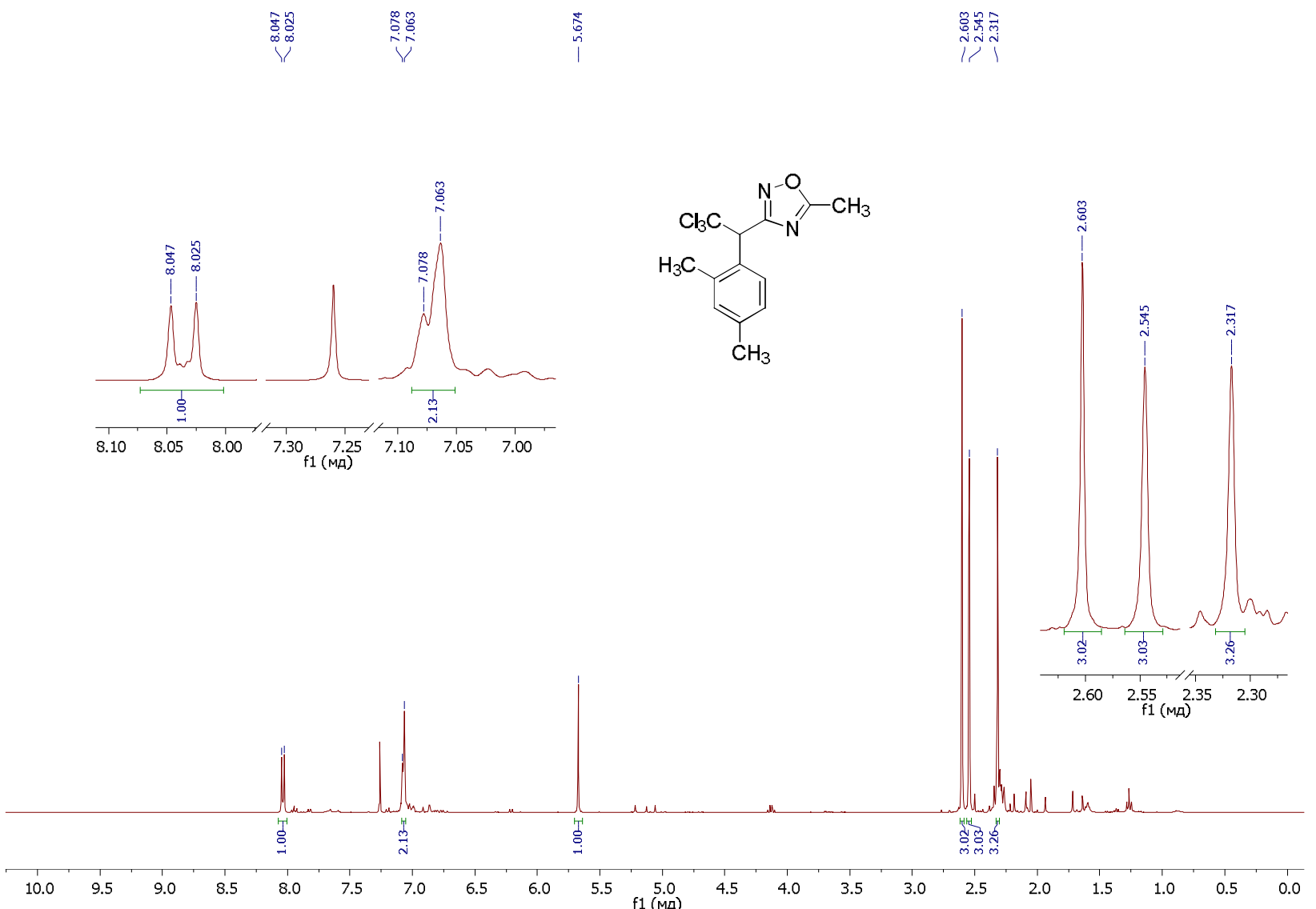

Fig. S22. ${ }^{1} \mathrm{H}$ NMR spectrum of the compound $\mathbf{2 h}\left(\mathrm{CDCl}_{3}, 400 \mathrm{MHz}\right)$. 


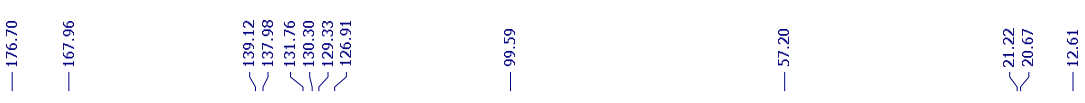
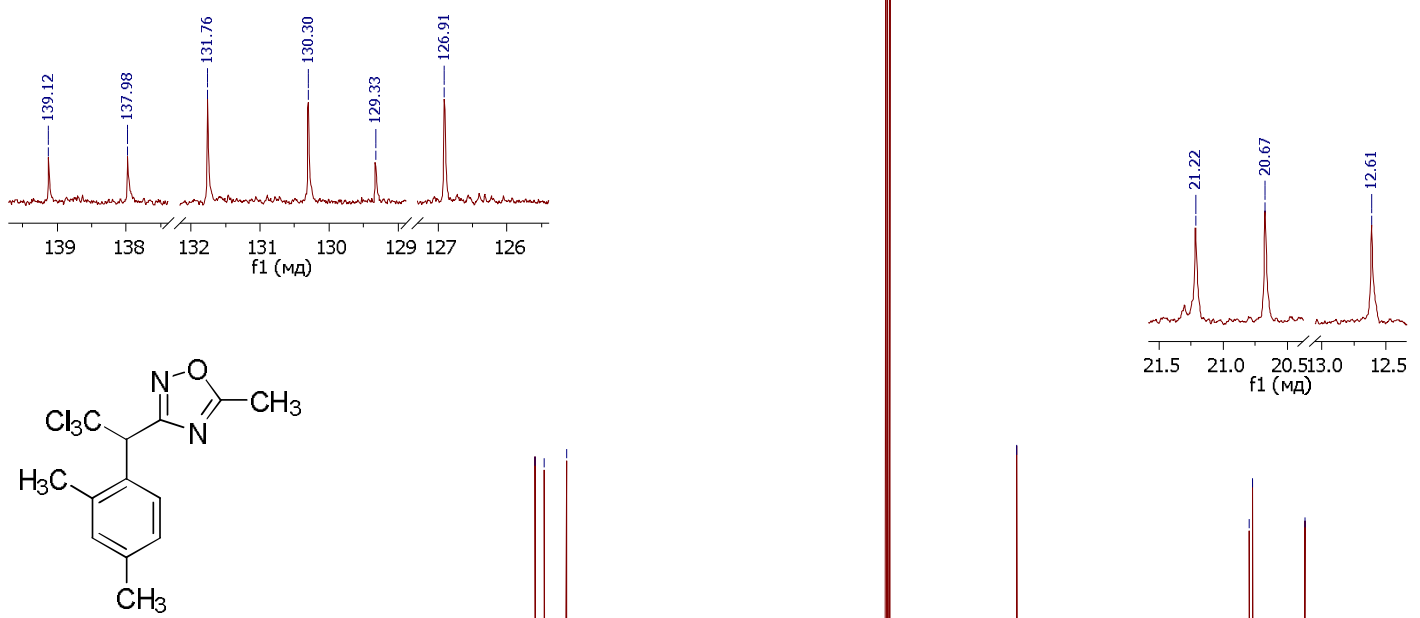

Fig. S23. ${ }^{13} \mathrm{C}\{\mathrm{H}\}$ NMR spectrum of the compound $\mathbf{2 h}\left(\mathrm{CDCl}_{3}, 101 \mathrm{MHz}\right)$.

Ф SHIMADZu
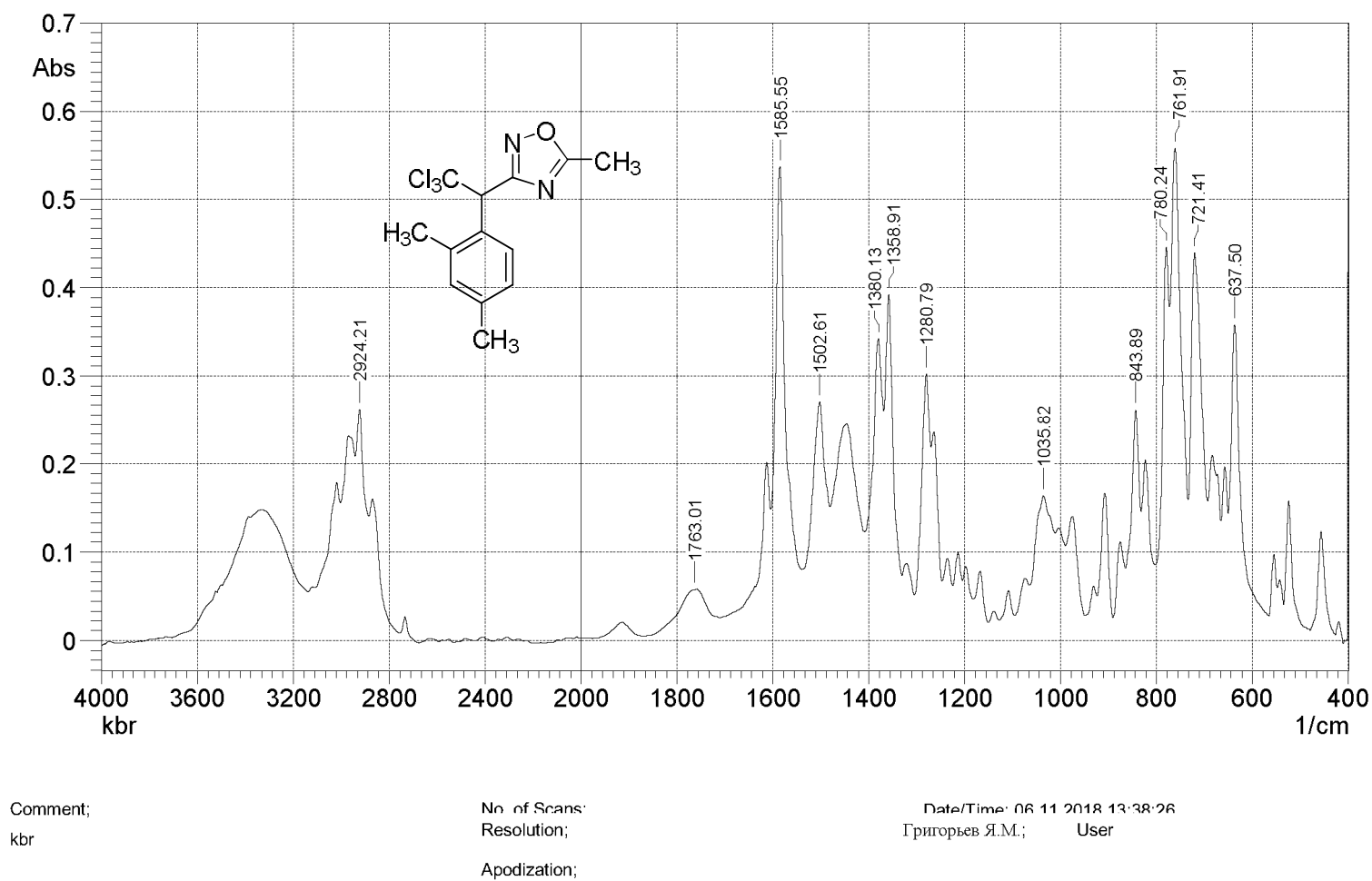

Fig. S24. IR spectrum of the compound $\mathbf{2 h}(\mathrm{KBr})$. 


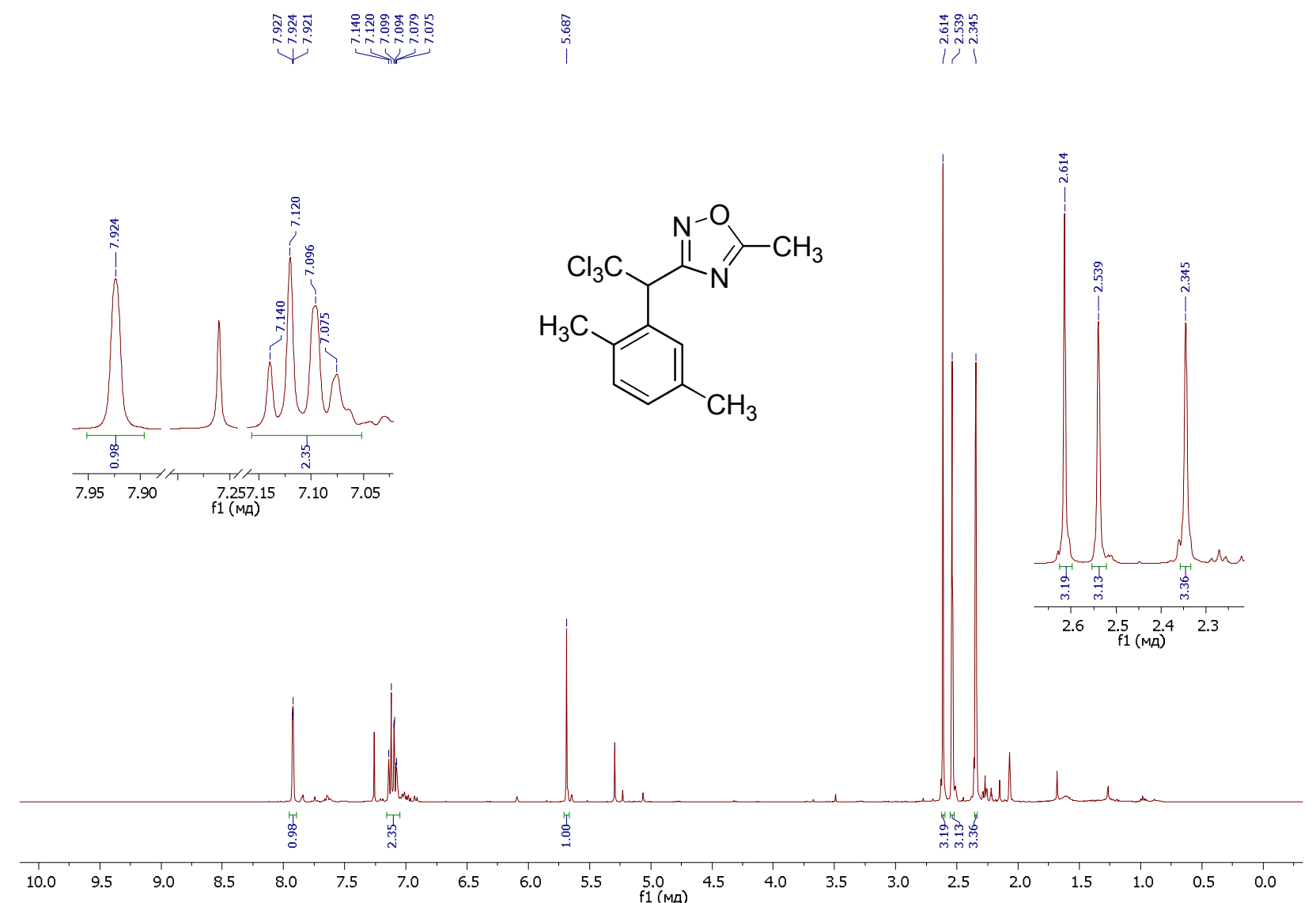

Fig. S25. ${ }^{1} \mathrm{H}$ NMR spectrum of the compound $2 \mathbf{i}\left(\mathrm{CDCl}_{3}, 400 \mathrm{MHz}\right)$.
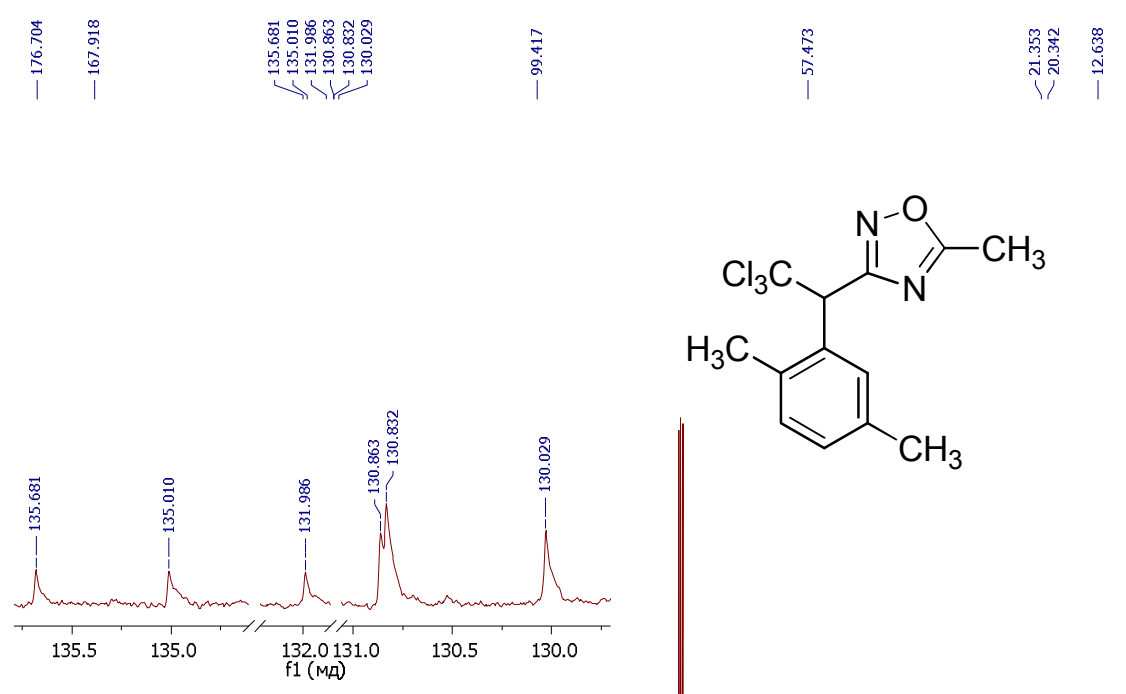

\begin{tabular}{llllllllllllllllllllllllllllllllll}
\hline 30 & 220 & 210 & 200 & 190 & 180 & 170 & 160 & 150 & 140 & 130 & 120 & 110 & 100 & 90 & 30 & 70 & 60 & 50 & 40 & 30 & 20 & 10 & 0 & -10 & -2
\end{tabular}

Fig. S26. ${ }^{13} \mathrm{C}\{\mathrm{H}\}$ NMR spectrum of the compound $2 \mathbf{i}\left(\mathrm{CDCl}_{3}, 101 \mathrm{MHz}\right)$. 


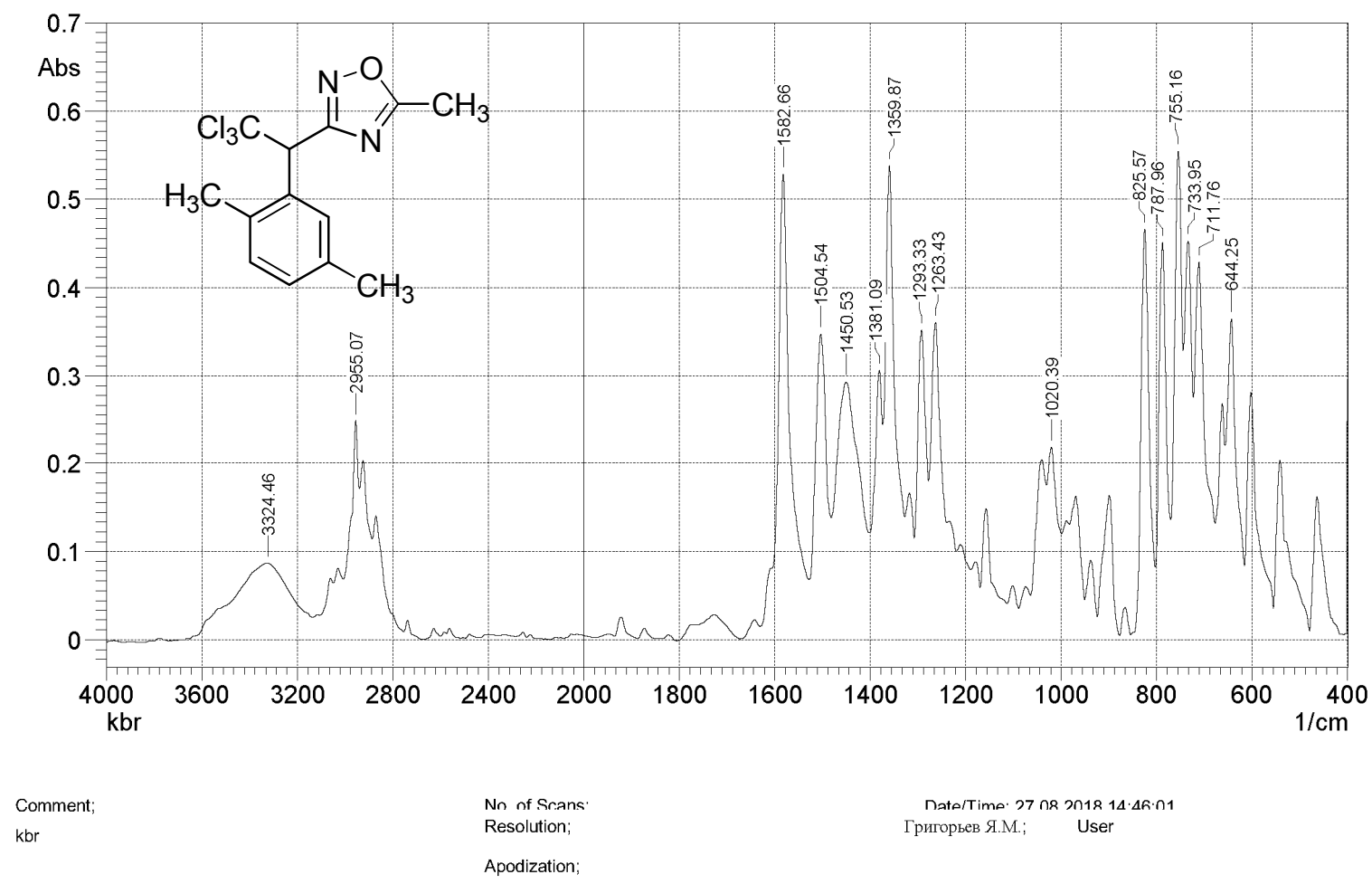

Fig. S27. IR spectrum of the compound $\mathbf{2 i}(\mathrm{KBr})$.
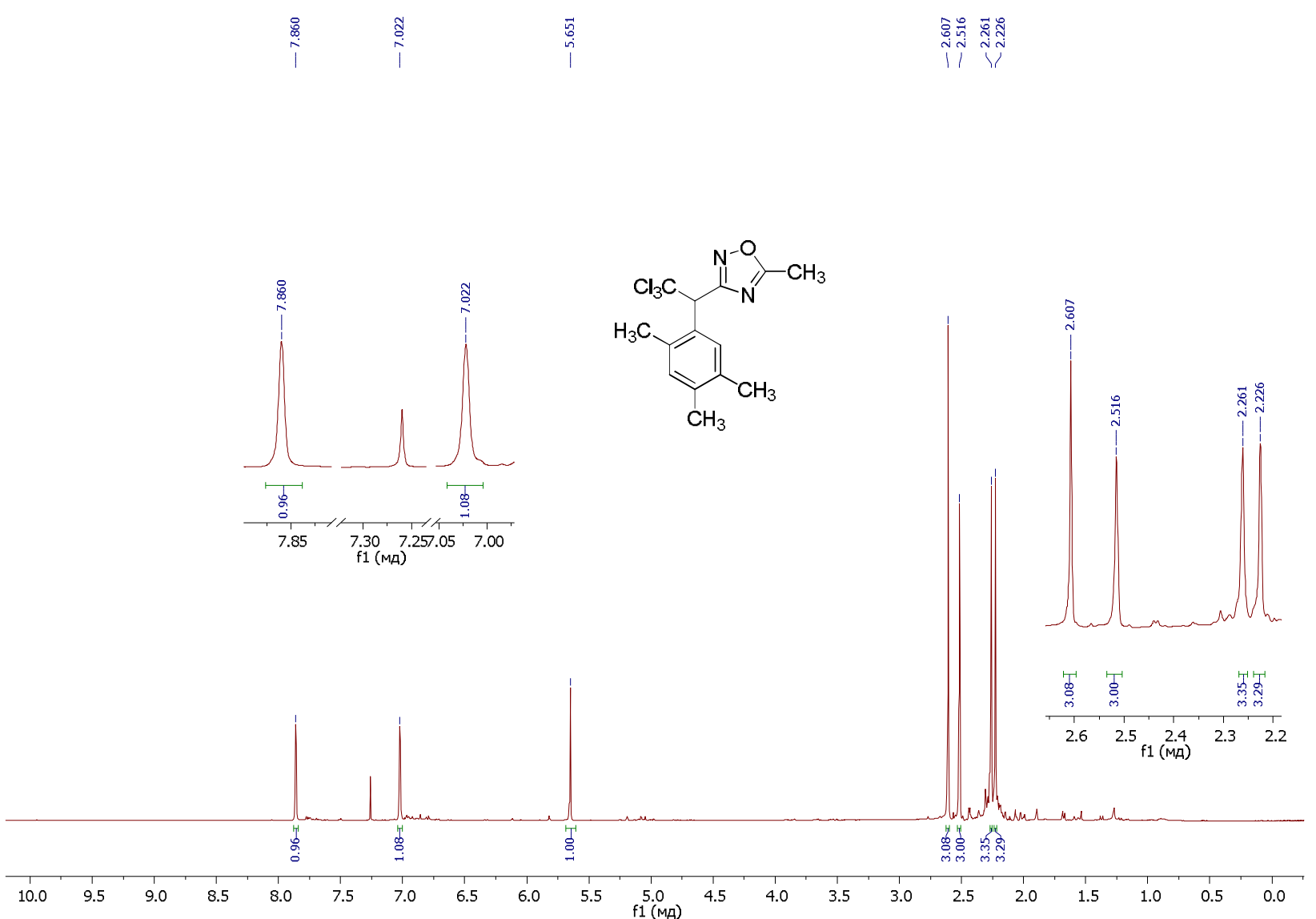

Fig. S28. ${ }^{1} \mathrm{H}$ NMR spectrum of the compound $2 \mathbf{j}\left(\mathrm{CDCl}_{3}, 400 \mathrm{MHz}\right)$. 


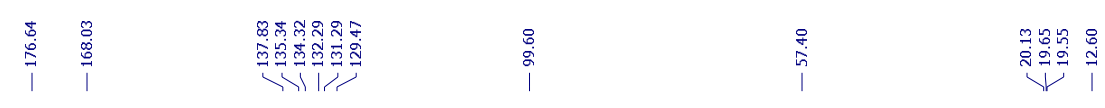
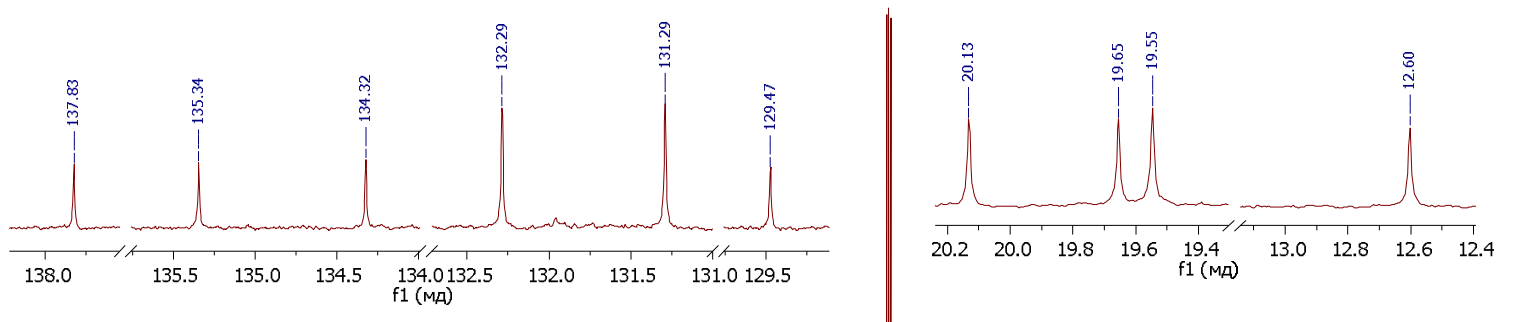<smiles>Cc1nc(C(c2cc(C)c(C)cc2C)C(Cl)(Cl)Cl)no1</smiles>

ФSHIMADZU

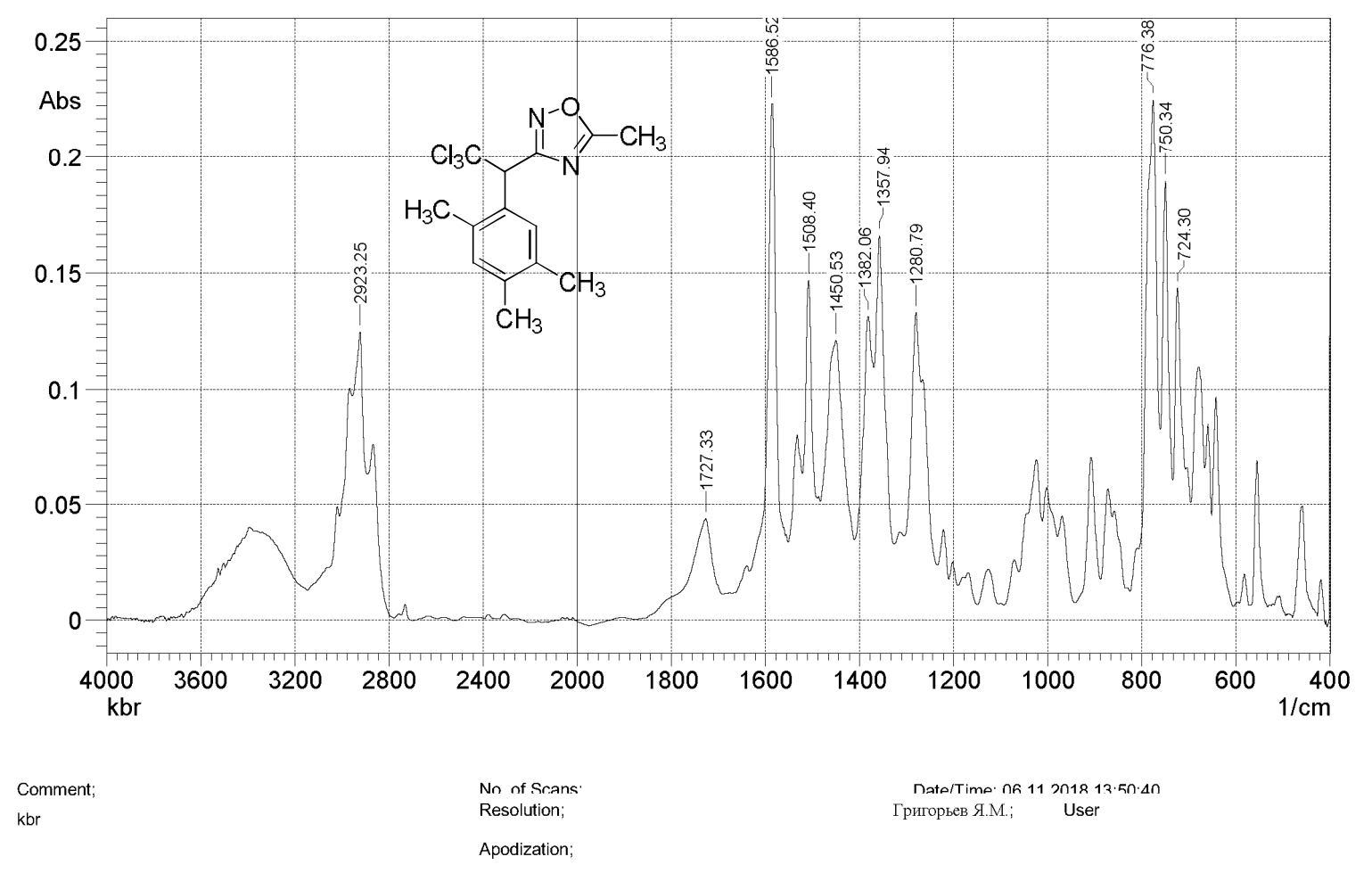

Fig. S30. IR spectrum of the compound $\mathbf{2} \mathbf{j}(\mathrm{KBr})$. 


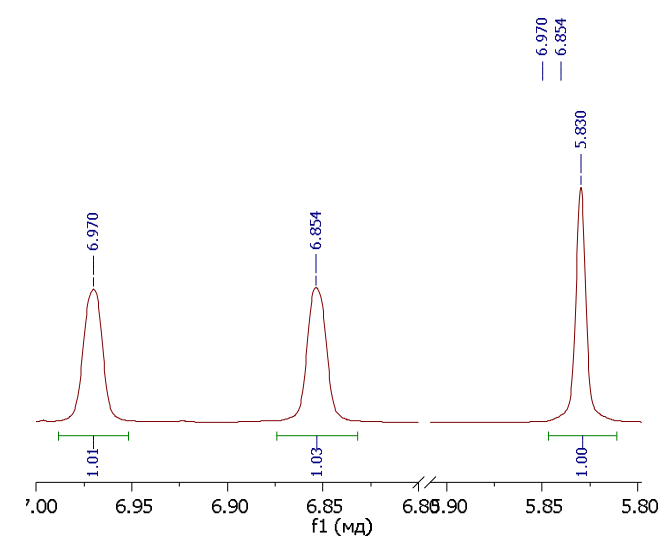

总㶽

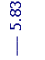

त)

f1 (MA)<smiles>Cc1cc(C)c(C(c2noc(C)n2)C(Cl)(Cl)Cl)c(C)c1</smiles>

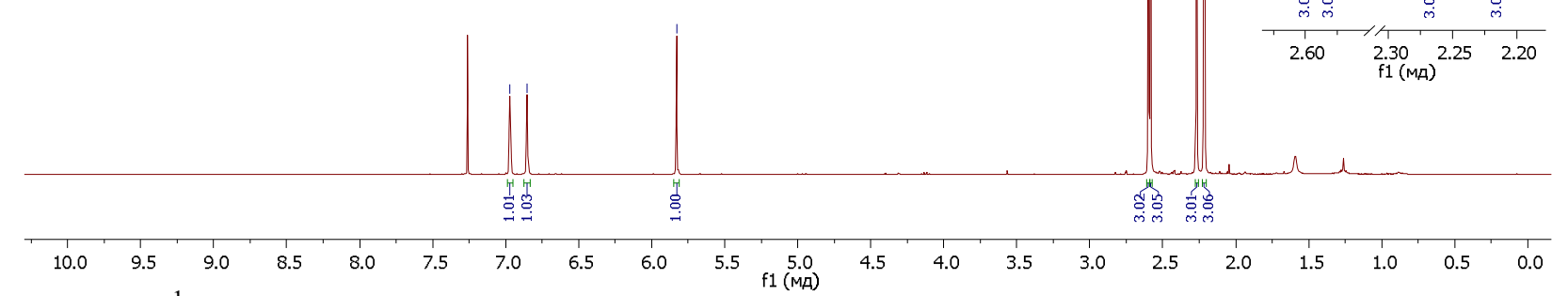

Fig. S31. ${ }^{1} \mathrm{H}$ NMR spectrum of the compound $\mathbf{2 k}\left(\mathrm{CDCl}_{3}, 400 \mathrm{MHz}\right)$.
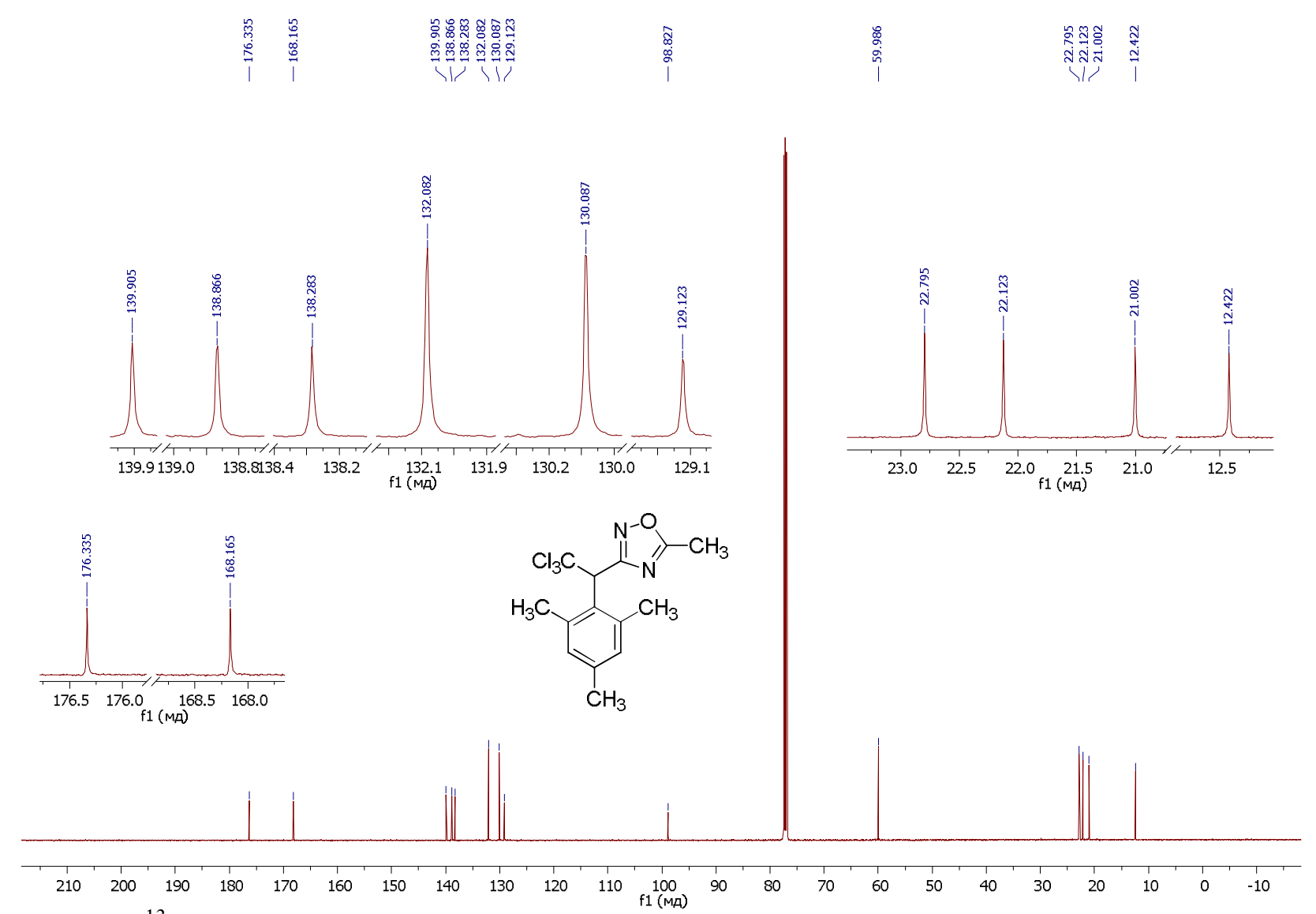

Fig. S32. ${ }^{13} \mathrm{C}\{\mathrm{H}\}$ NMR spectrum of the compound $\mathbf{2 k}\left(\mathrm{CDCl}_{3}, 101 \mathrm{MHz}\right)$. 


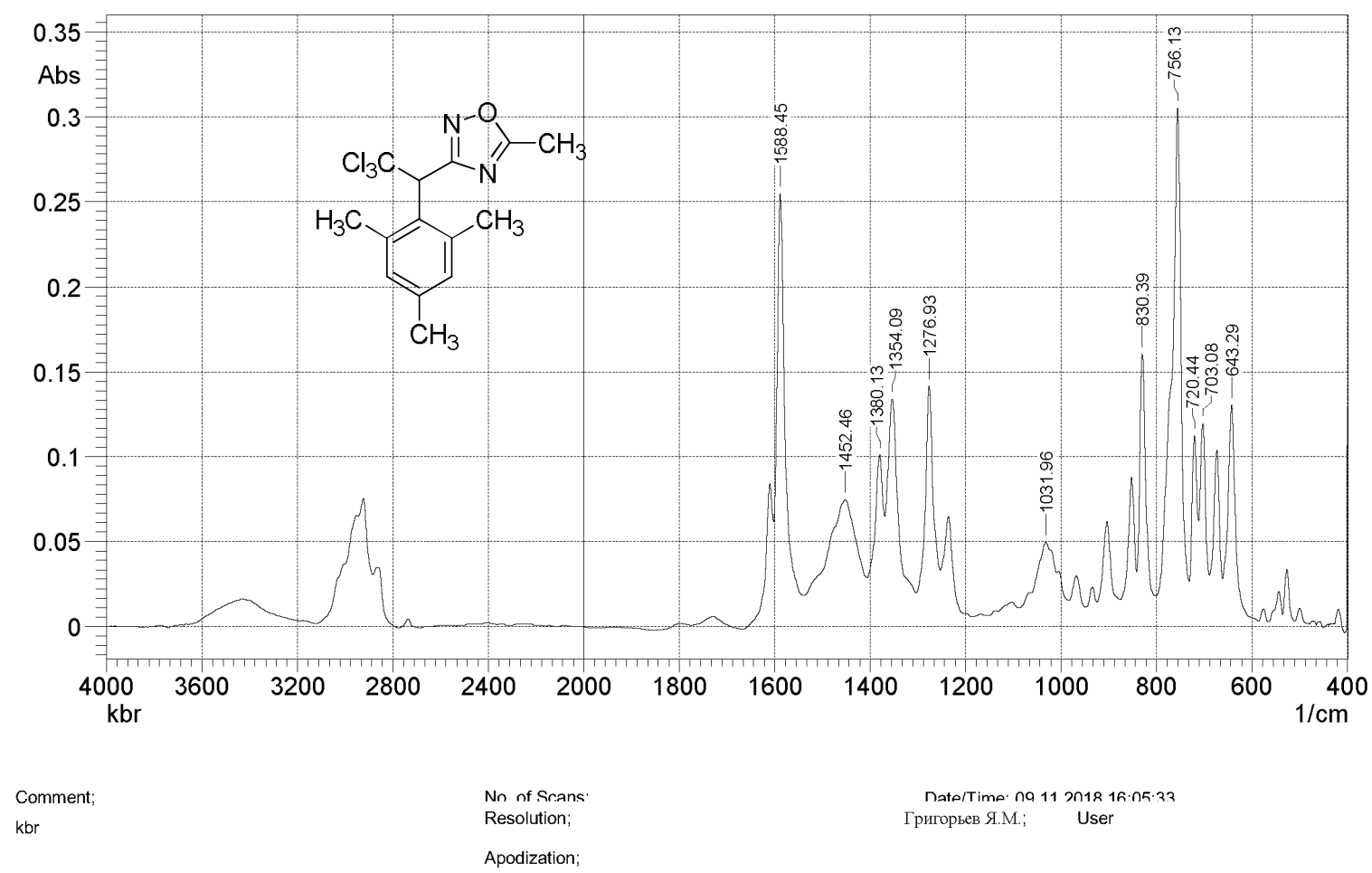

Fig. S33. IR spectrum of the compound $\mathbf{2 k}(\mathrm{KBr})$.
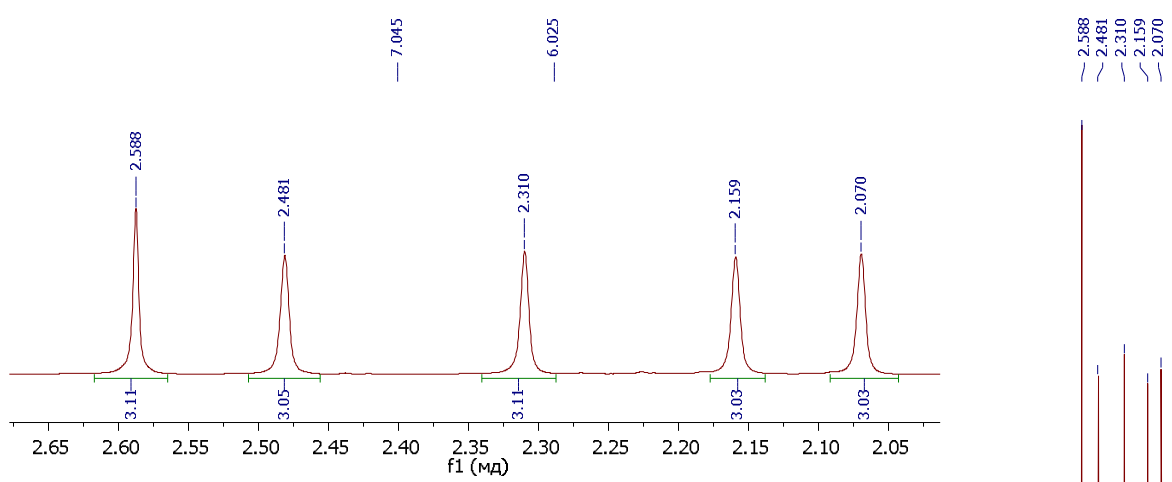<smiles>Cc1nc(C(c2c(C)c(C)cc(C)c2C)C(Cl)(Cl)Cl)no1</smiles>

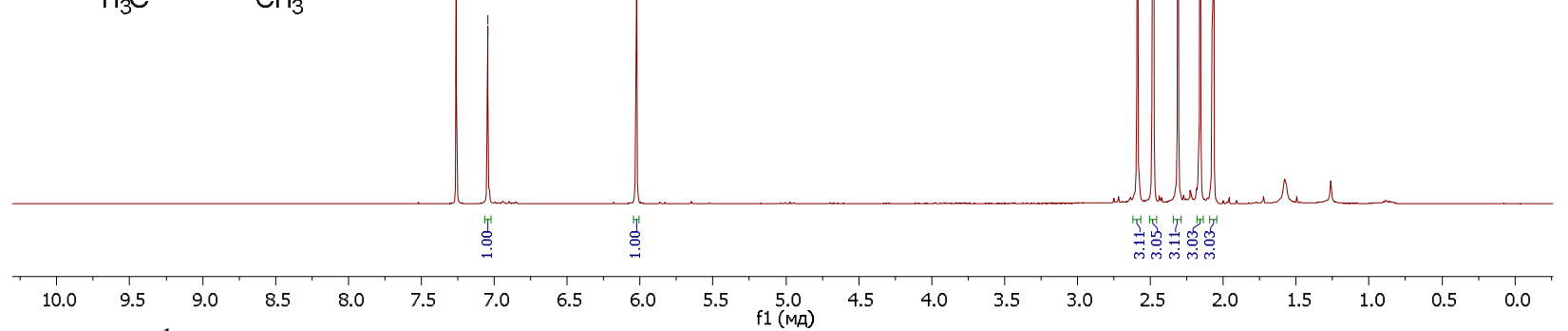

Fig. S34. ${ }^{1} \mathrm{H}$ NMR spectrum of the compound $21\left(\mathrm{CDCl}_{3}, 400 \mathrm{MHz}\right)$. 


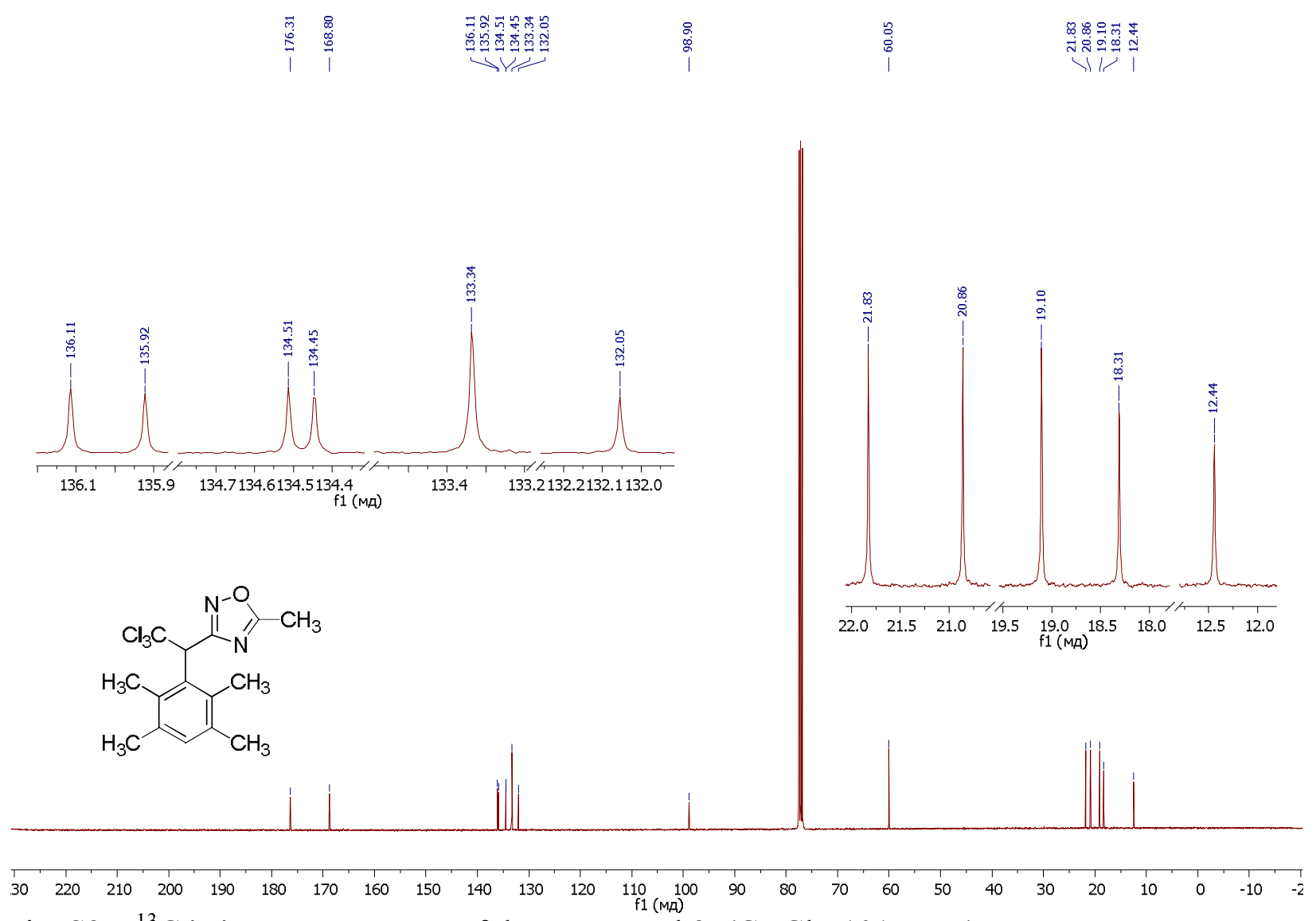

Fig. S35. ${ }^{13} \mathrm{C}\{\mathrm{H}\} \mathrm{NMR}$ spectrum of the compound $2 \mathrm{l}\left(\mathrm{CDCl}_{3}, 101 \mathrm{MHz}\right)$.

ФSHIMADZU

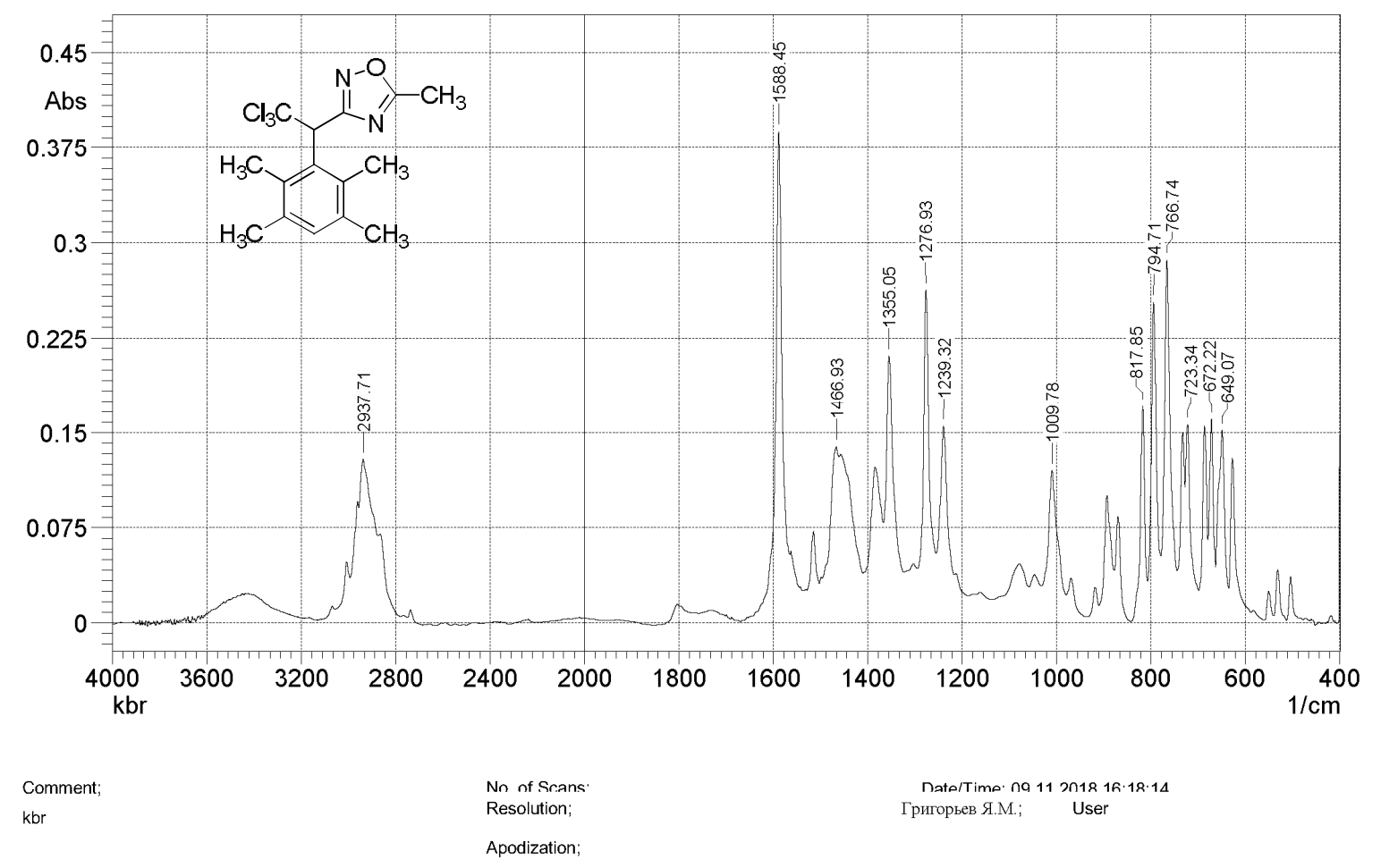

Fig. S36. IR spectrum of the compound $21(\mathrm{KBr})$. 


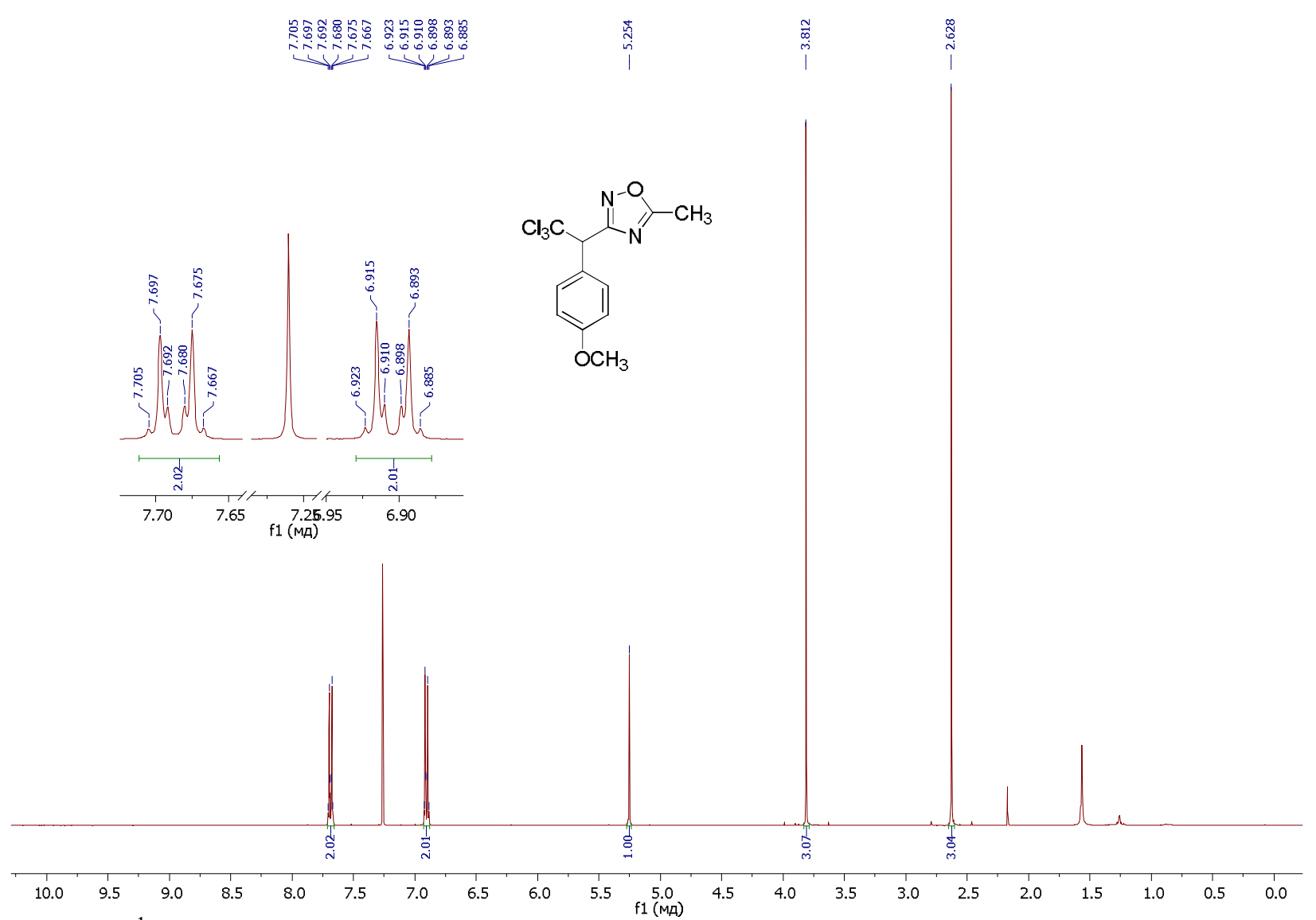

Fig. S37. ${ }^{1} \mathrm{H}$ NMR spectrum of the compound $\mathbf{2} \mathbf{m}\left(\mathrm{CDCl}_{3}, 400 \mathrm{MHz}\right)$.

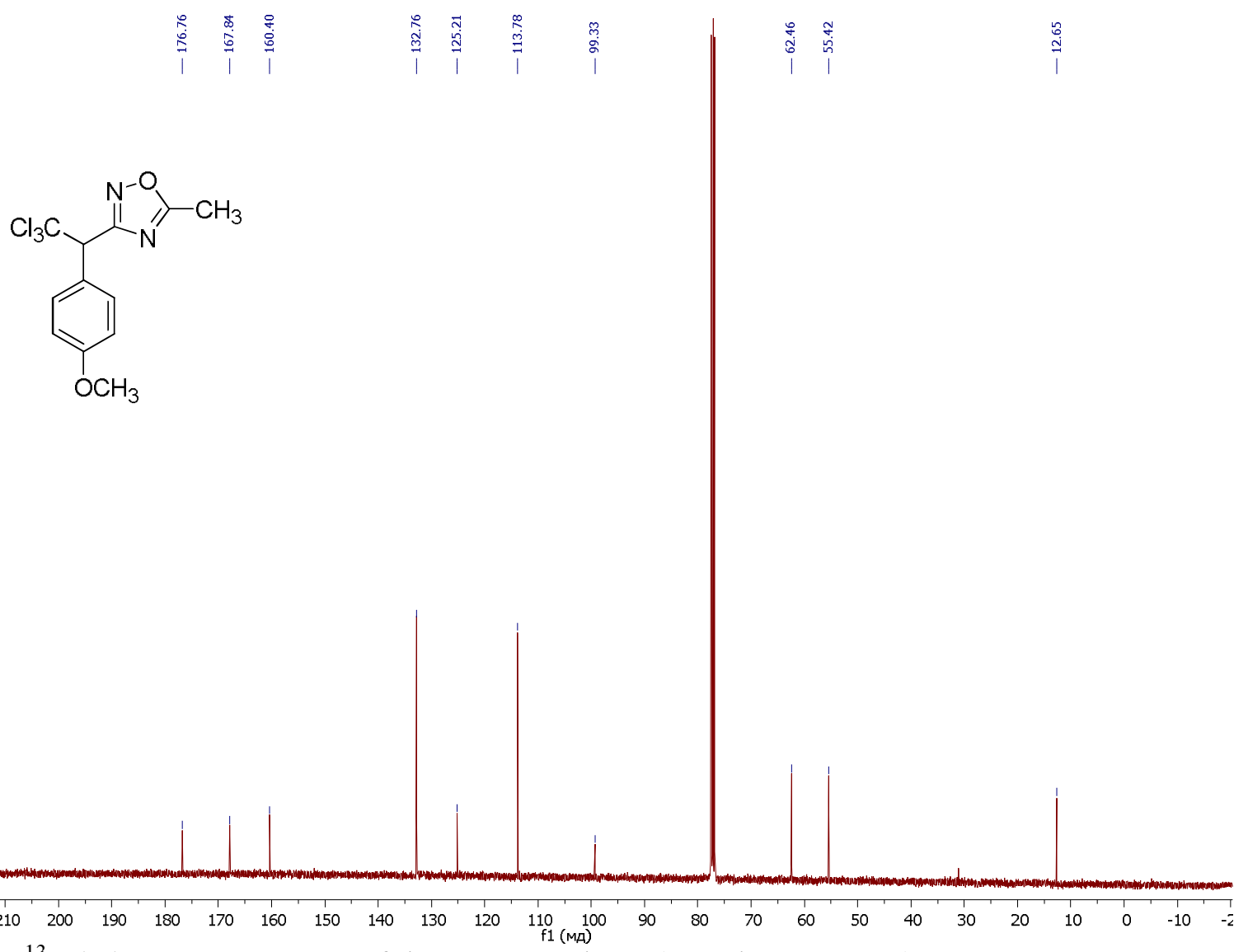

Fig. S38. ${ }^{13} \mathrm{C}\{\mathrm{H}\}$ NMR spectrum of the compound $\mathbf{2 m}\left(\mathrm{CDCl}_{3}, 101 \mathrm{MHz}\right)$. 

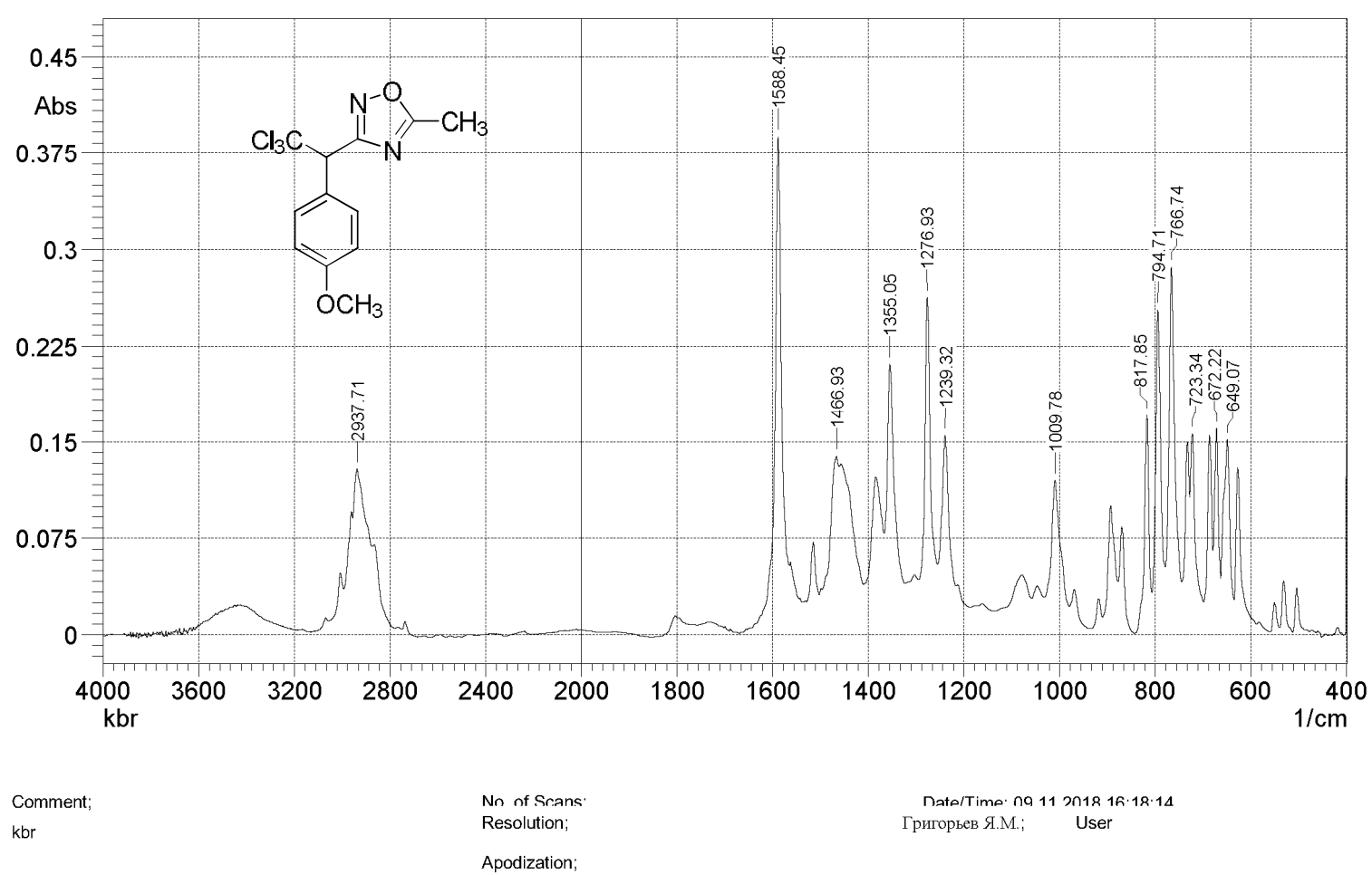

Fig. S39. IR spectrum of the compound $\mathbf{2 m}(\mathrm{KBr})$.

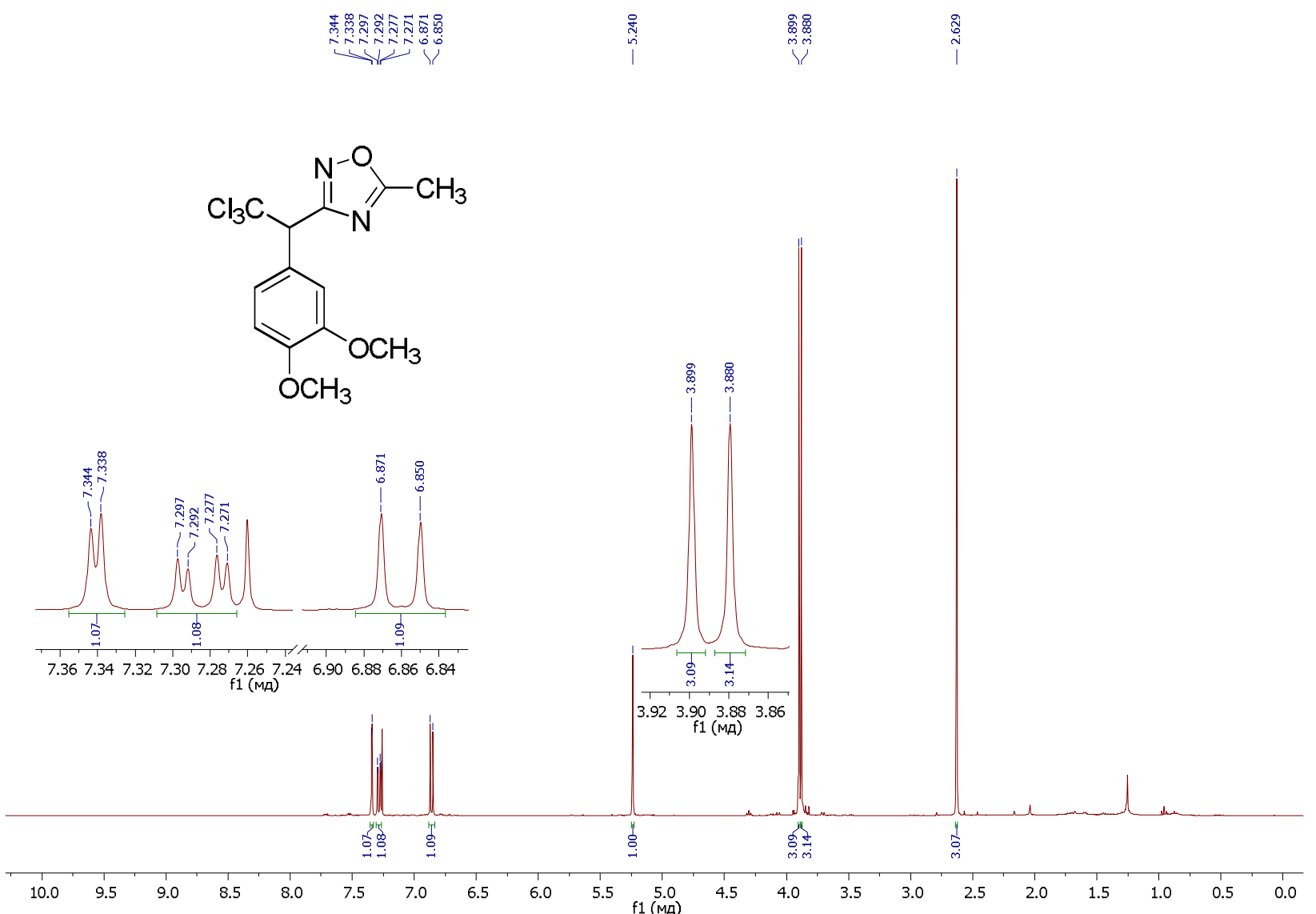

Fig. S40. ${ }^{1} \mathrm{H}$ NMR spectrum of the compound $\mathbf{2 n}\left(\mathrm{CDCl}_{3}, 400 \mathrm{MHz}\right)$. 


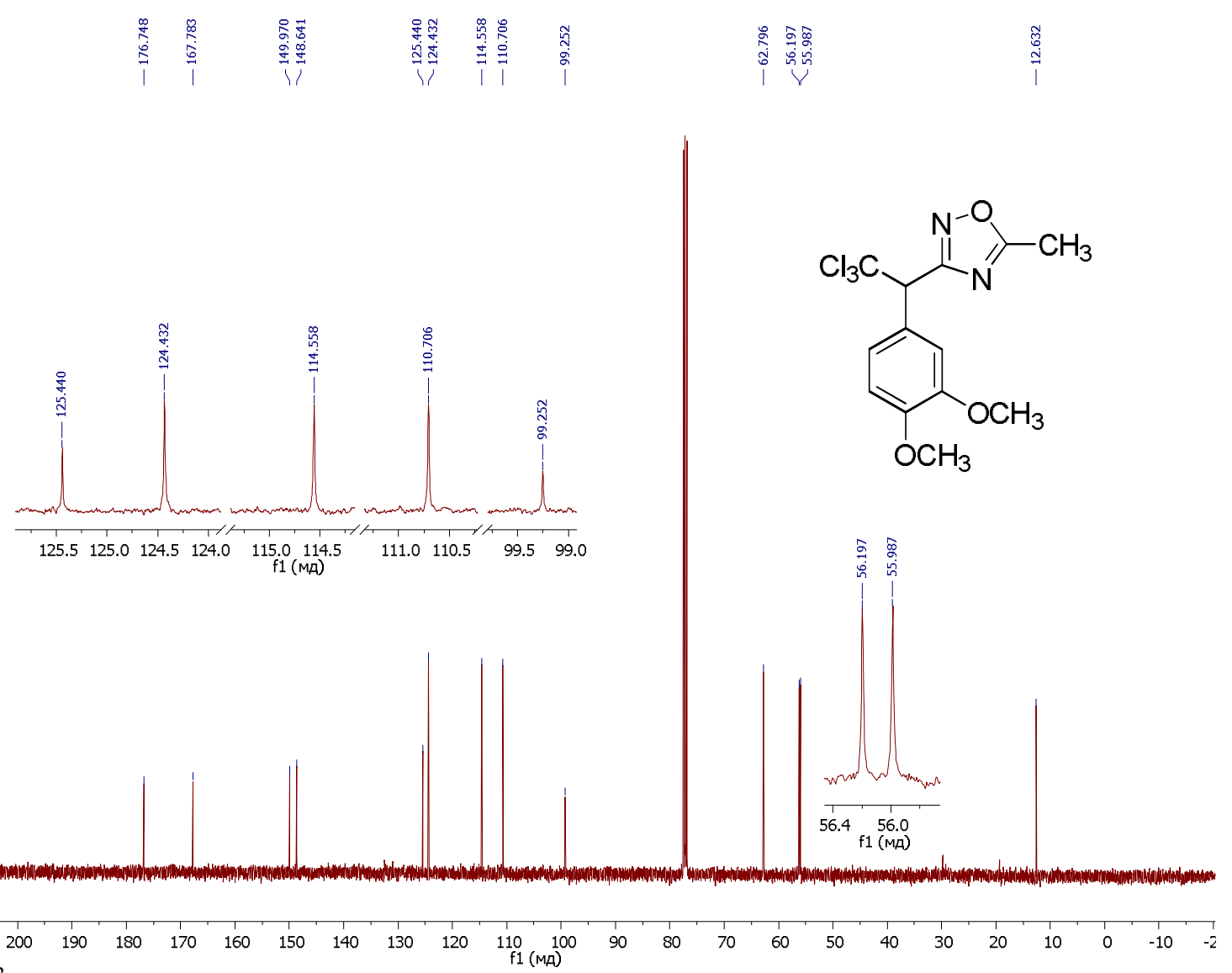

Fig. $\mathrm{S} 41 .{ }^{13} \mathrm{C}\{\mathrm{H}\}$ NMR spectrum of the compound $2 \mathbf{n}\left(\mathrm{CDCl}_{3}, 101 \mathrm{MHz}\right)$.

ФsHIMADZu

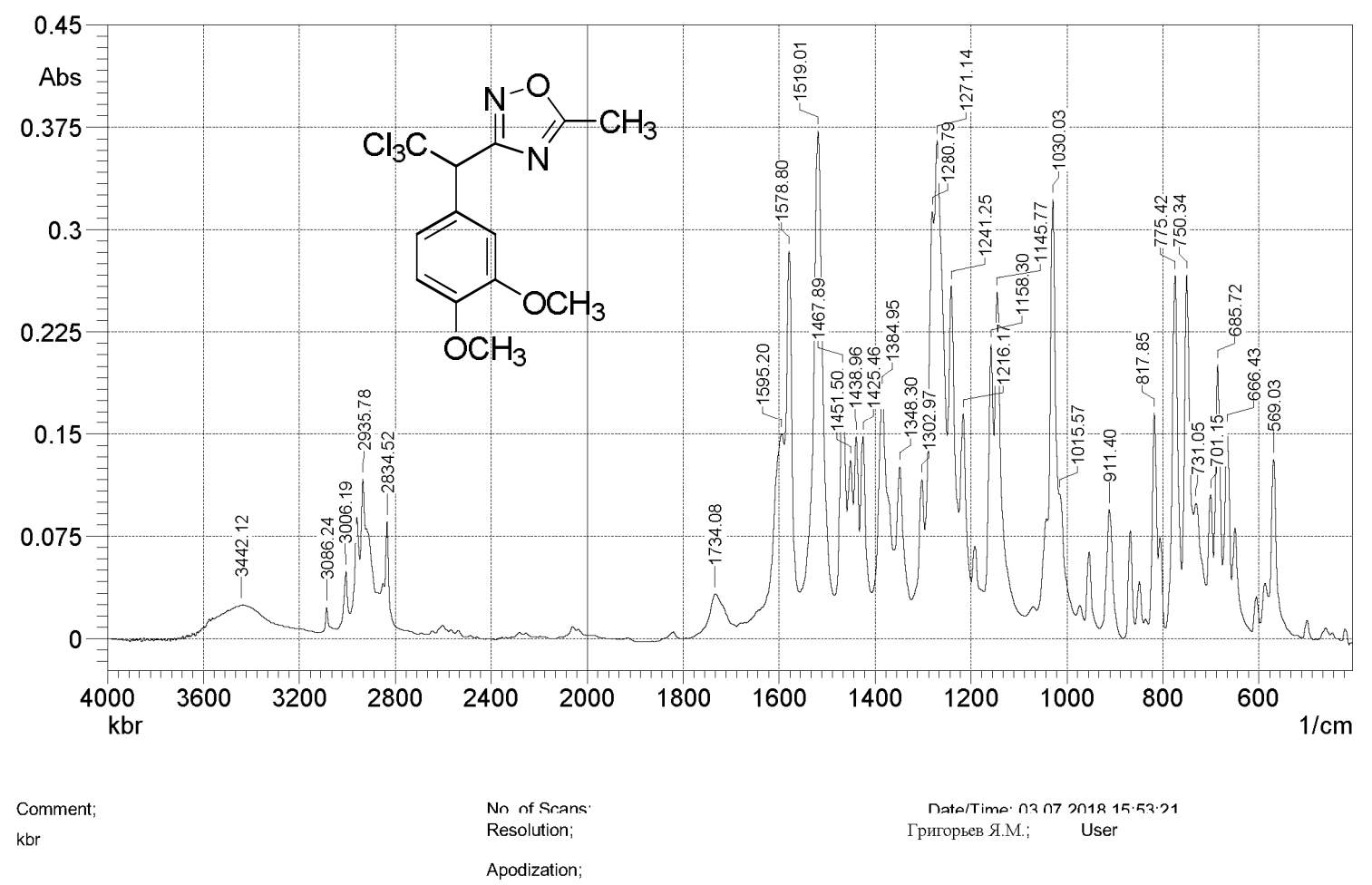

Fig. S42. IR spectrum of the compound $2 \mathbf{n}(\mathrm{KBr})$. 


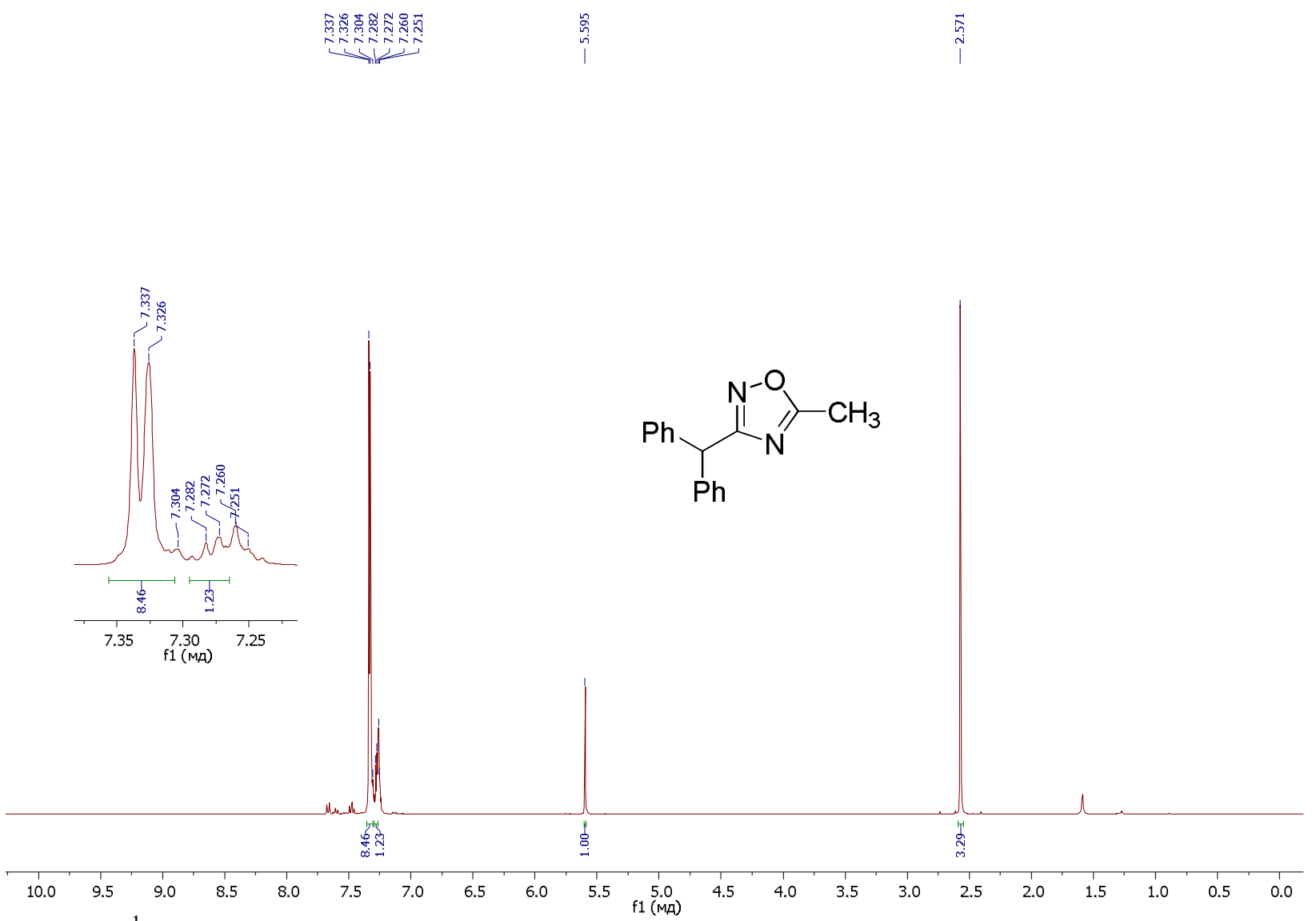

Fig. S43. ${ }^{1} \mathrm{H}$ NMR spectrum of the compound $20\left(\mathrm{CDCl}_{3}, 400 \mathrm{MHz}\right)$.
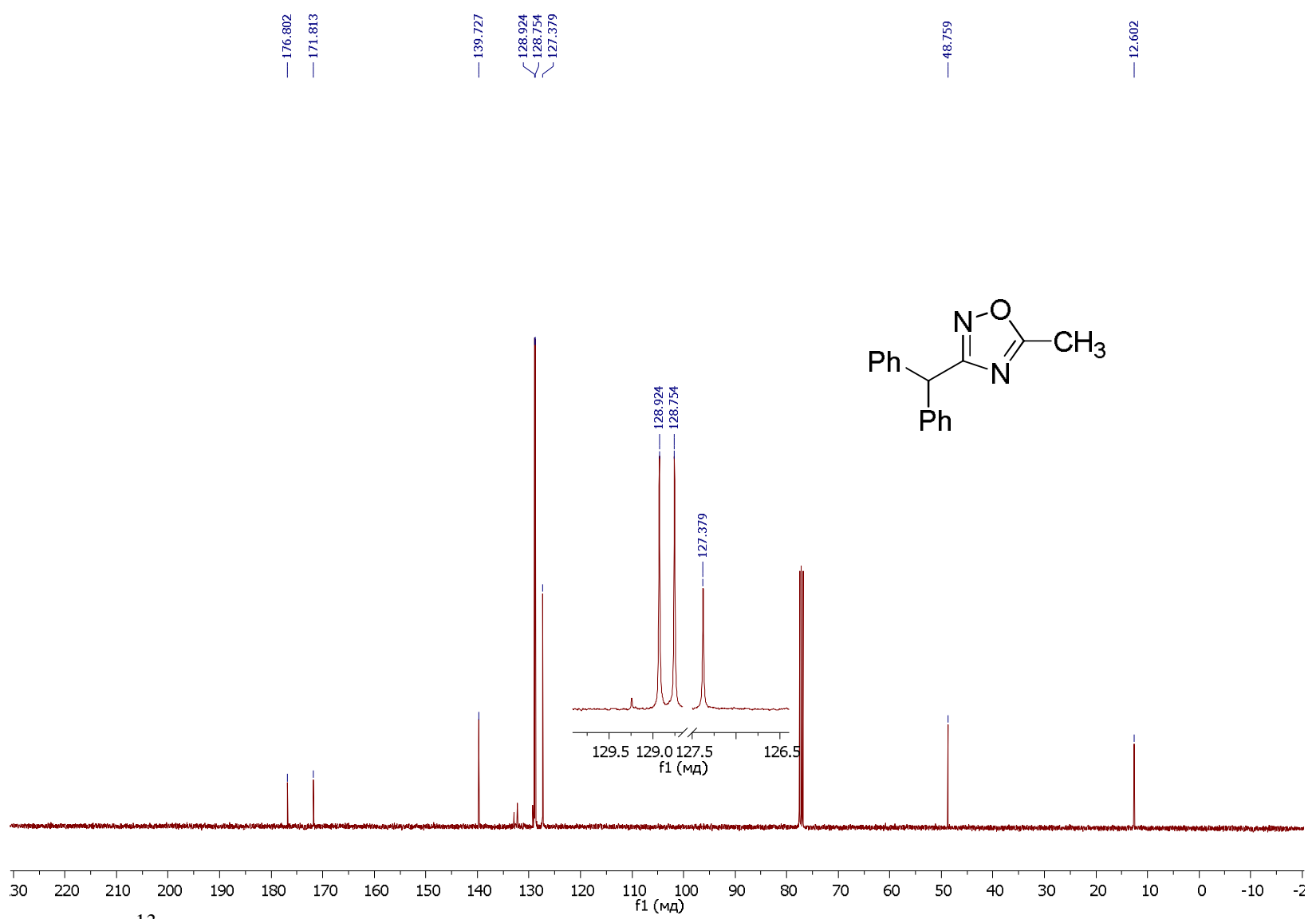

Fig. S44. ${ }^{13} \mathrm{C}\{\mathrm{H}\}$ NMR spectrum of the compound $20\left(\mathrm{CDCl}_{3}, 101 \mathrm{MHz}\right)$. 


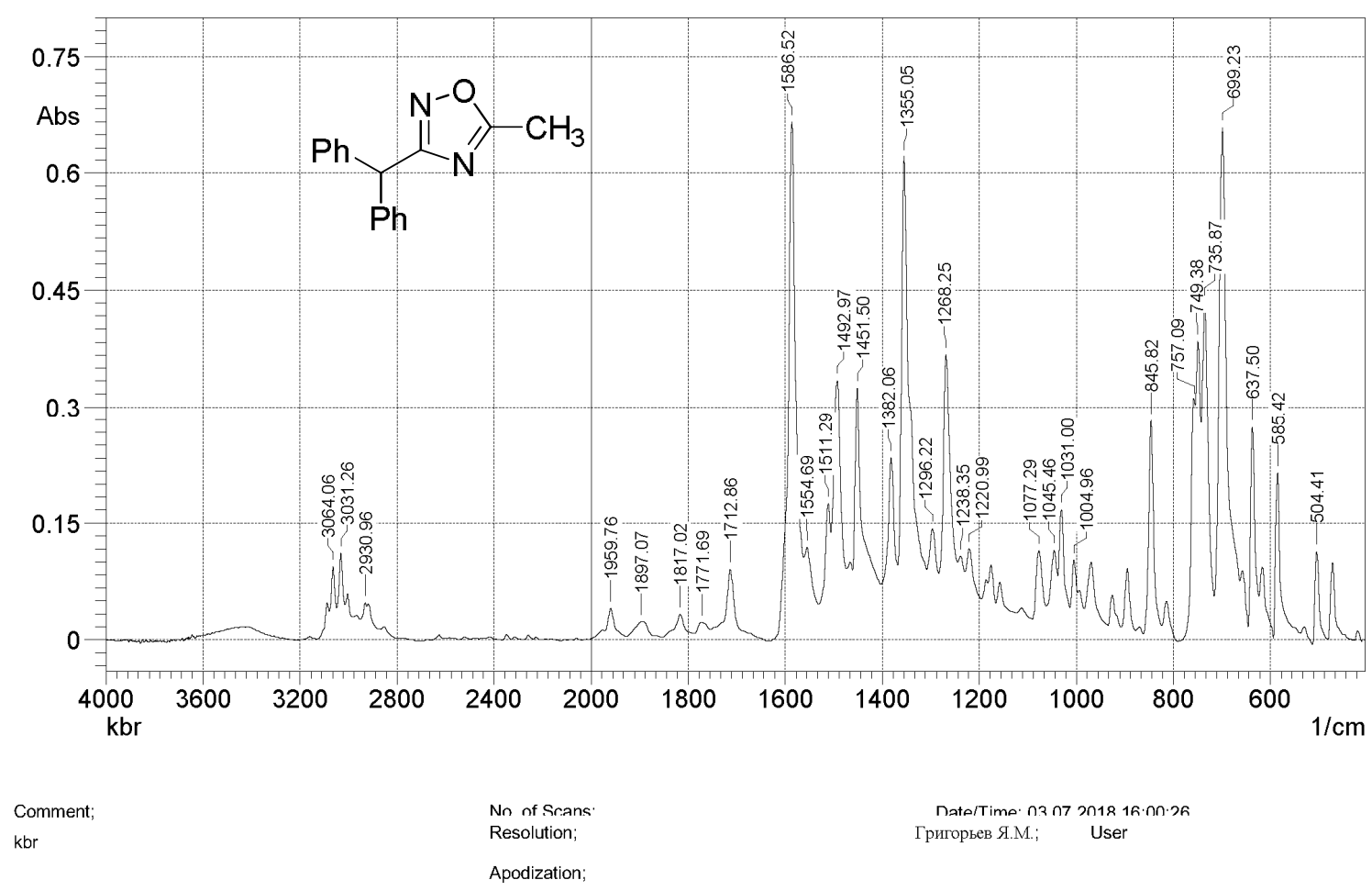

Fig. S45. IR spectrum of the compound $20(\mathrm{KBr})$.
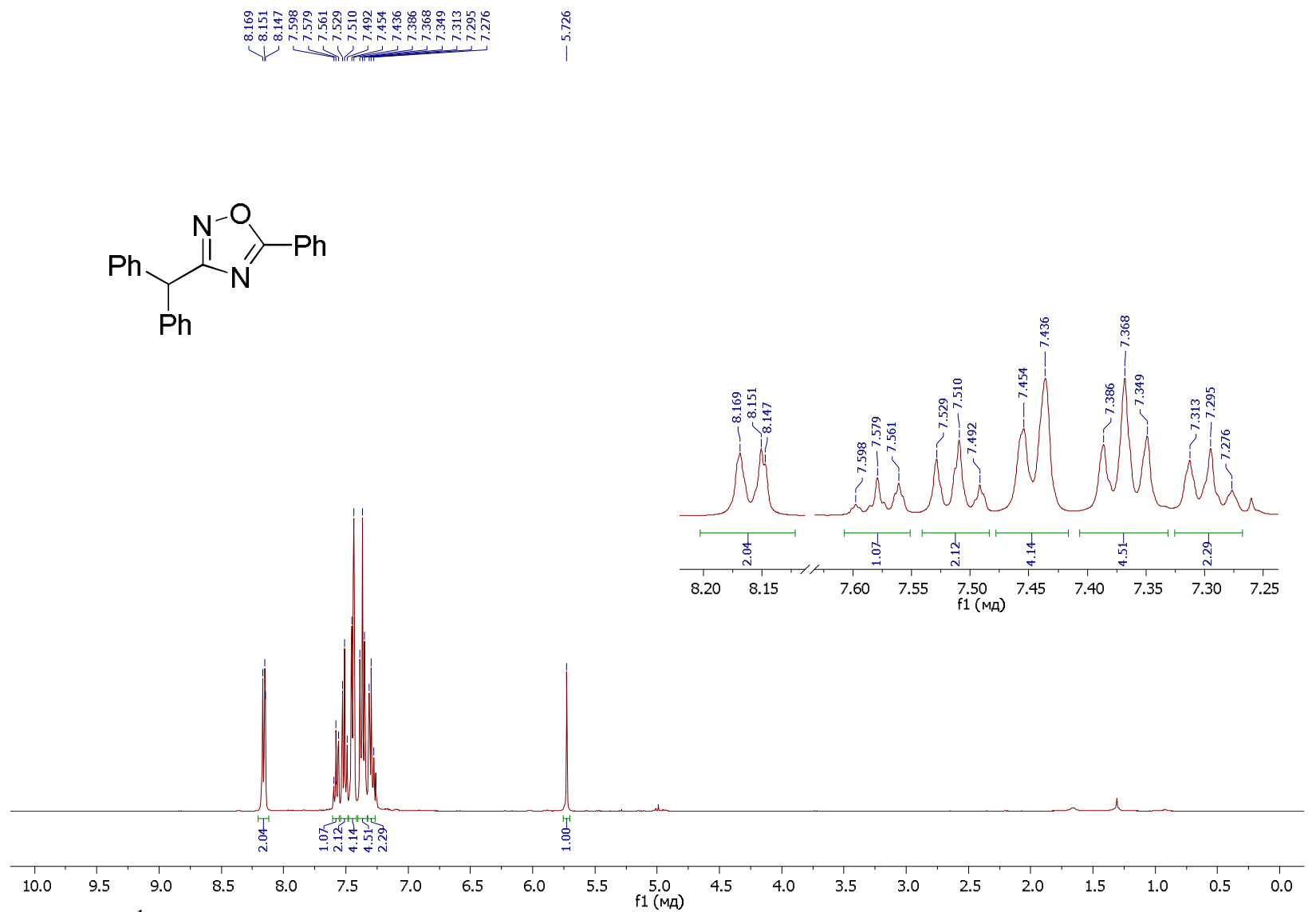

Fig. S46. ${ }^{1} \mathrm{H}$ NMR spectrum of the compound $\mathbf{2 p}\left(\mathrm{CDCl}_{3}, 400 \mathrm{MHz}\right)$. 

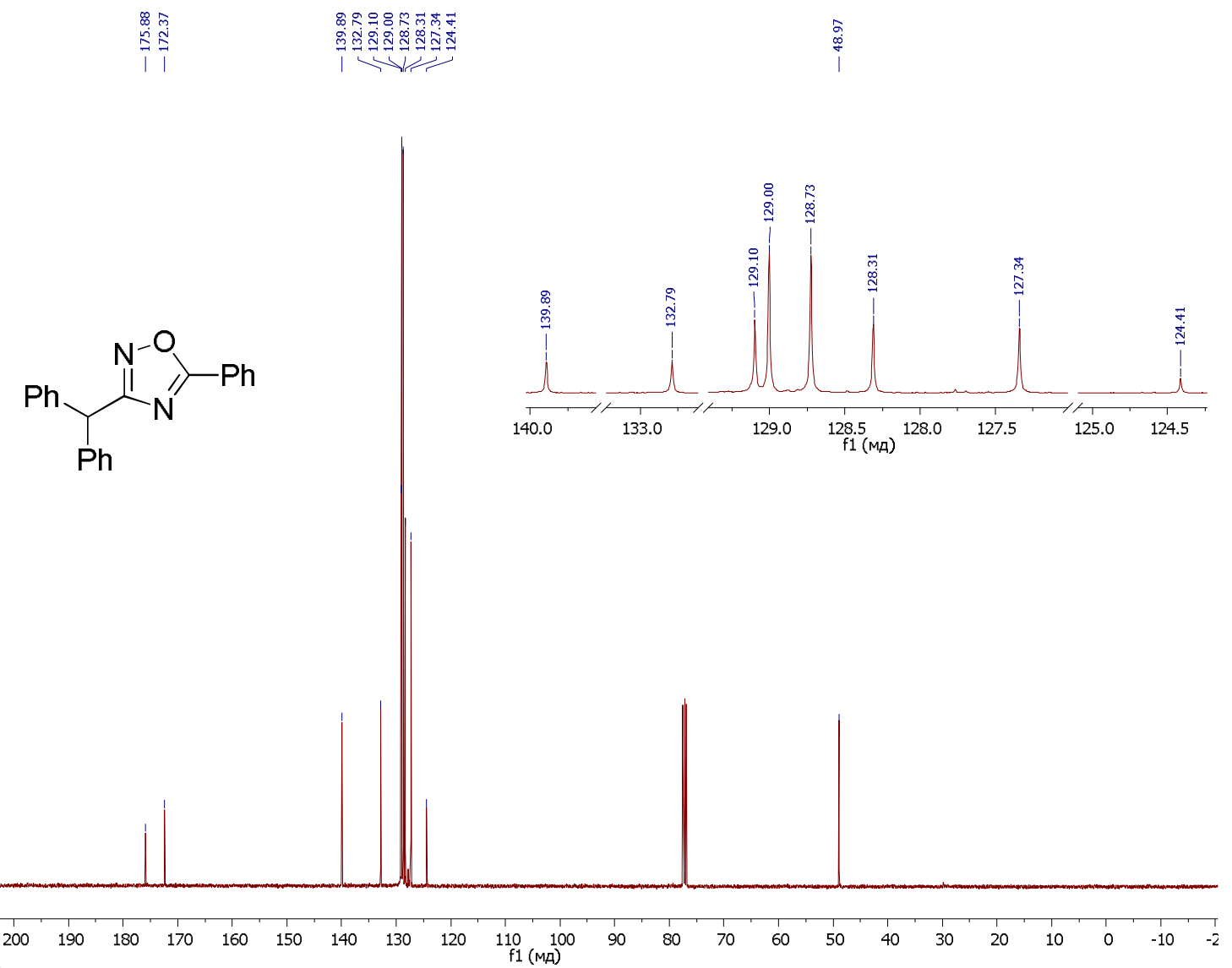

Fig. S47. ${ }^{13} \mathrm{C}\{\mathrm{H}\}$ NMR spectrum of the compound $\mathbf{2 p}\left(\mathrm{CDCl}_{3}, 101 \mathrm{MHz}\right)$.

ФSHIMADZu

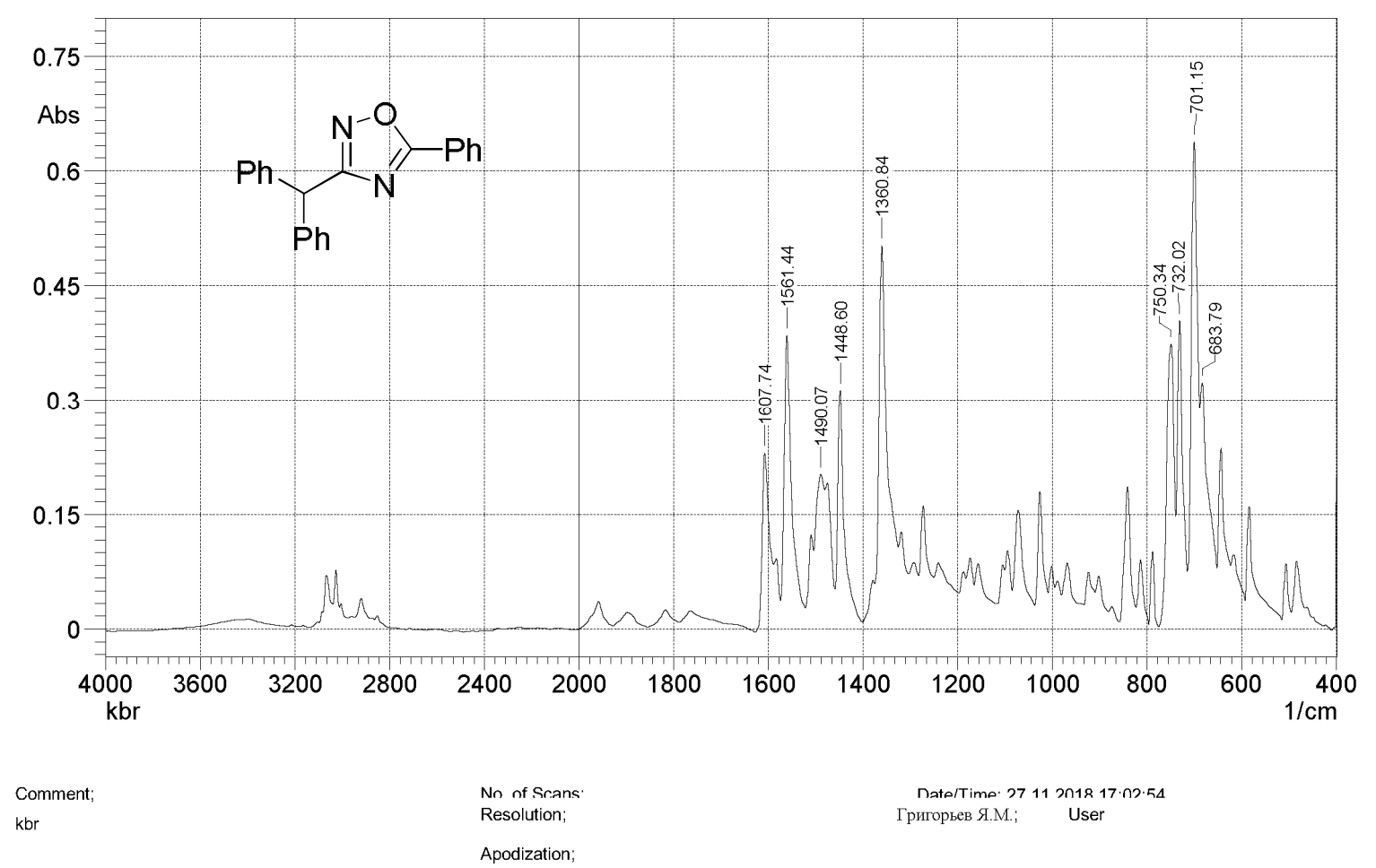

Fig. S48. IR spectrum of the compound $\mathbf{2 p}(\mathrm{KBr})$. 


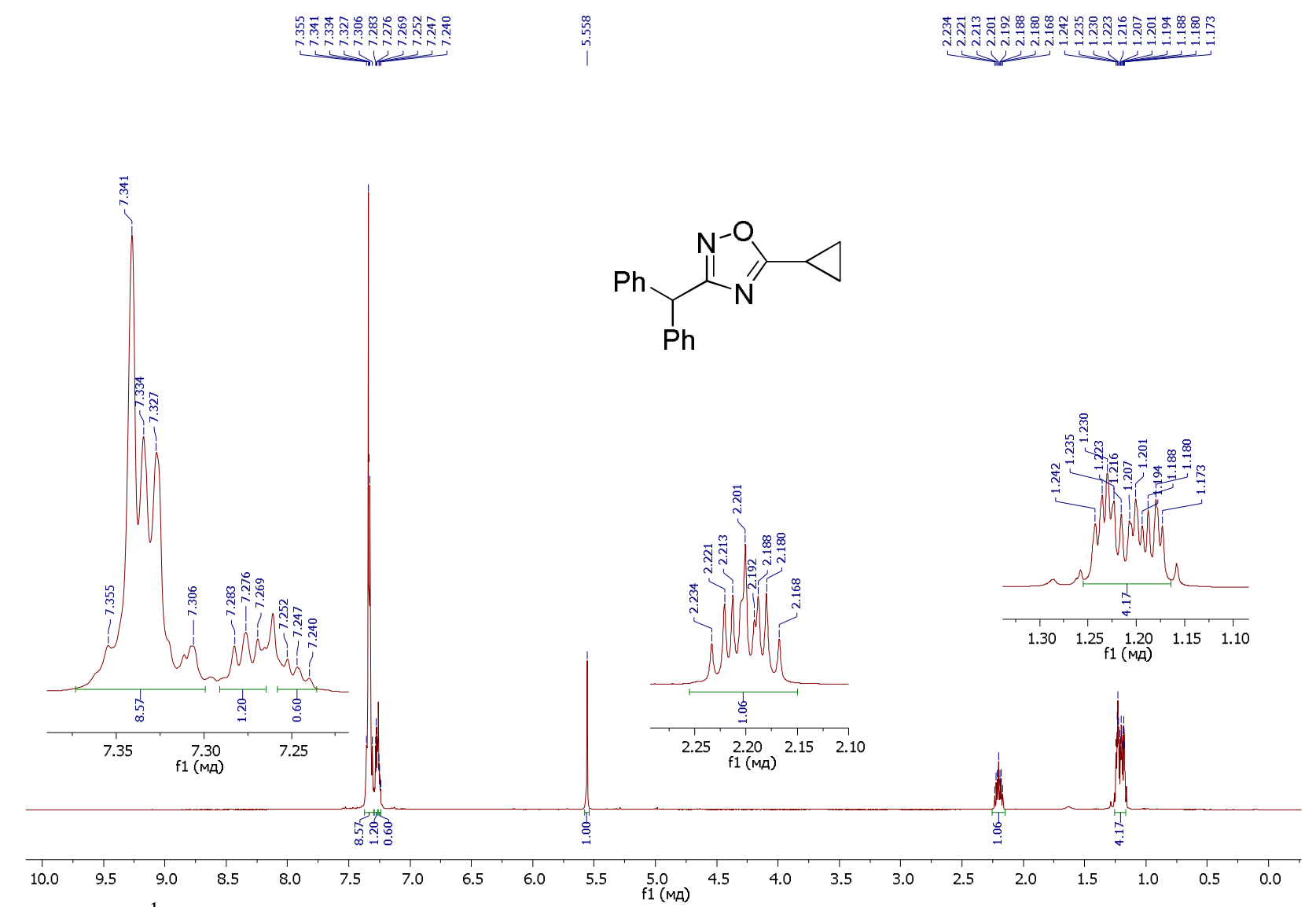

Fig. S49. ${ }^{1} \mathrm{H}$ NMR spectrum of the compound $\mathbf{2 q}\left(\mathrm{CDCl}_{3}, 400 \mathrm{MHz}\right)$.
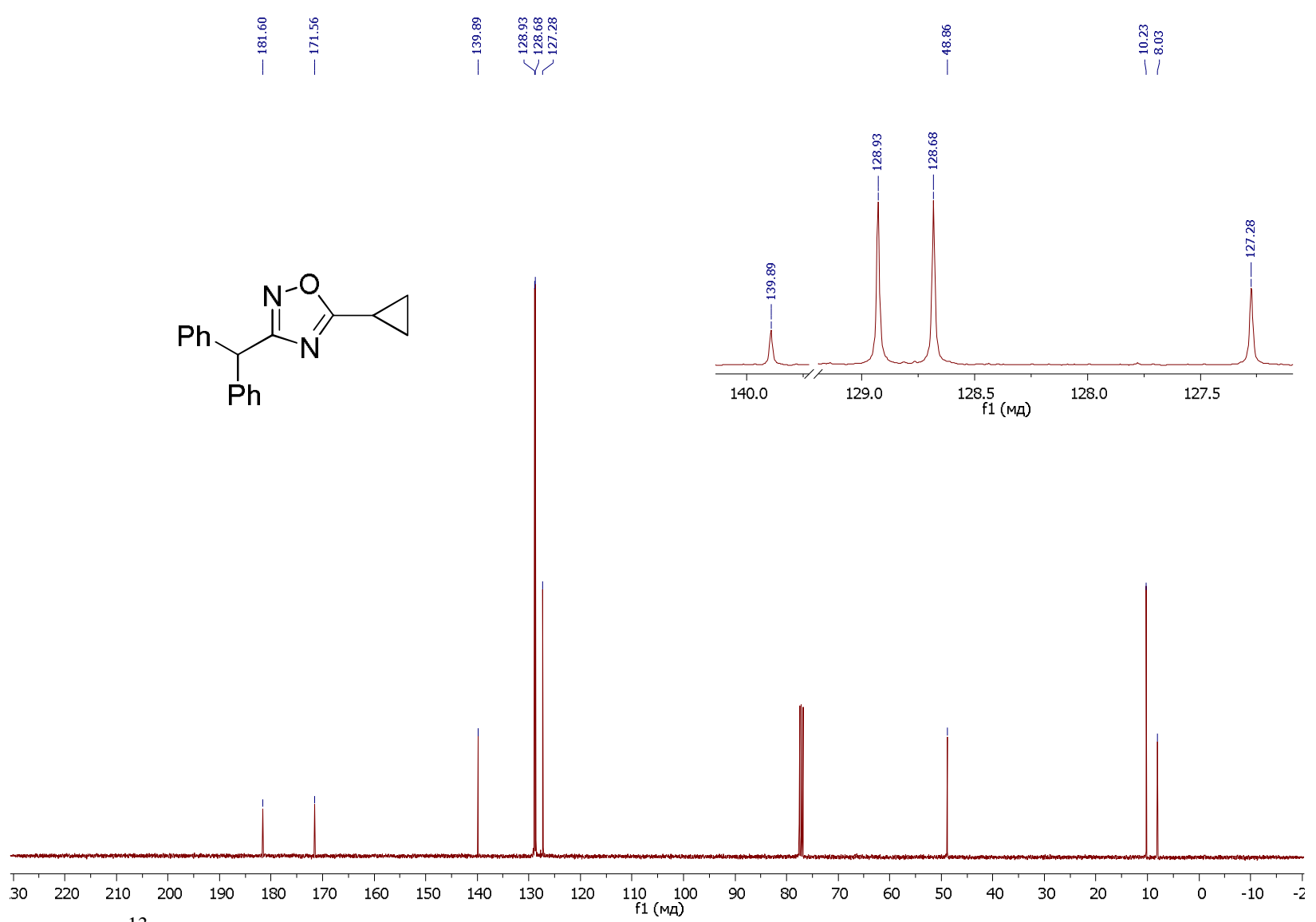

Fig. S50. ${ }^{13} \mathrm{C}\{\mathrm{H}\}$ NMR spectrum of the compound $\mathbf{2 q}\left(\mathrm{CDCl}_{3}, 101 \mathrm{MHz}\right)$. 

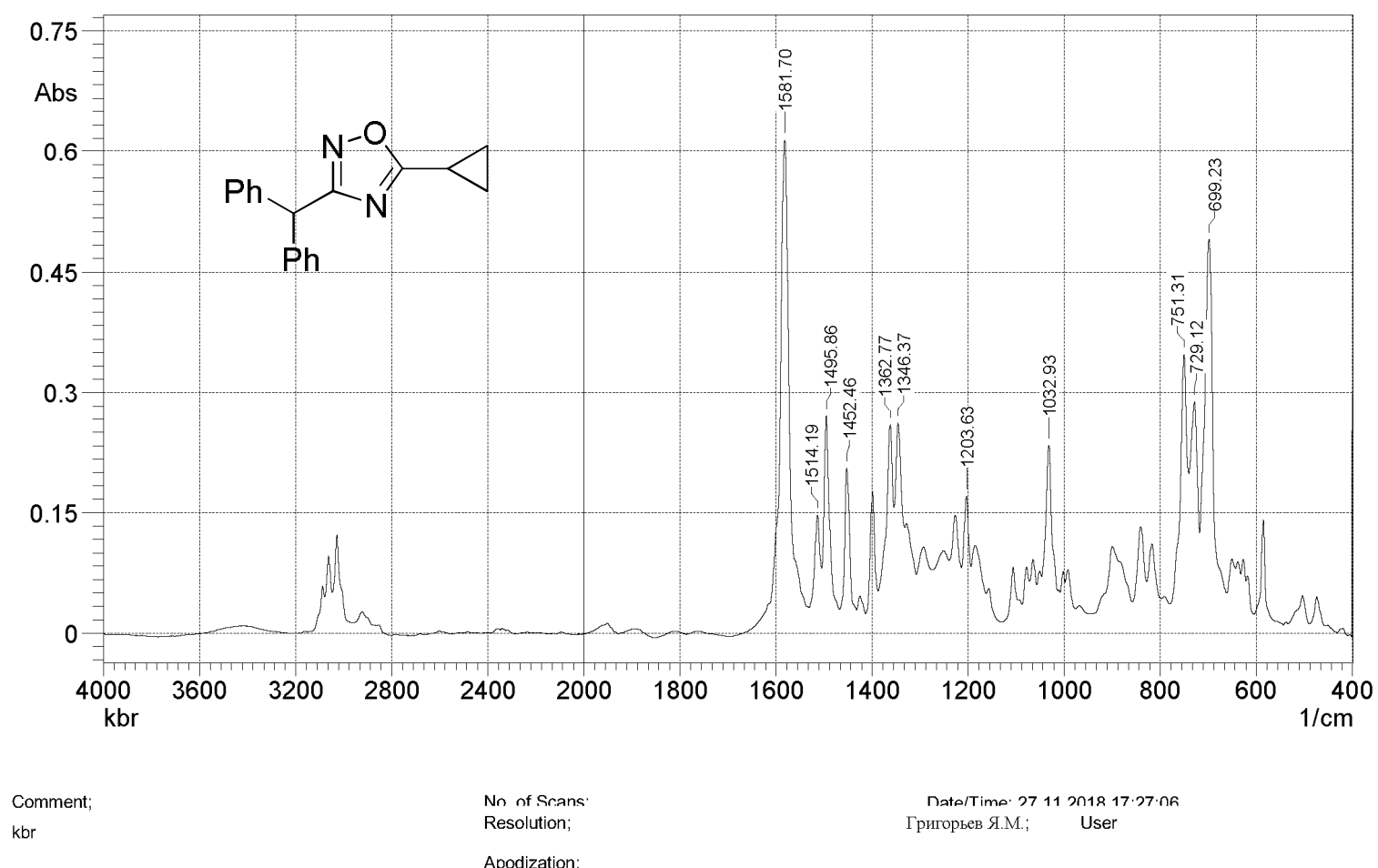

Fig. S51. IR spectrum of the compound $\mathbf{2 q}(\mathrm{KBr})$.

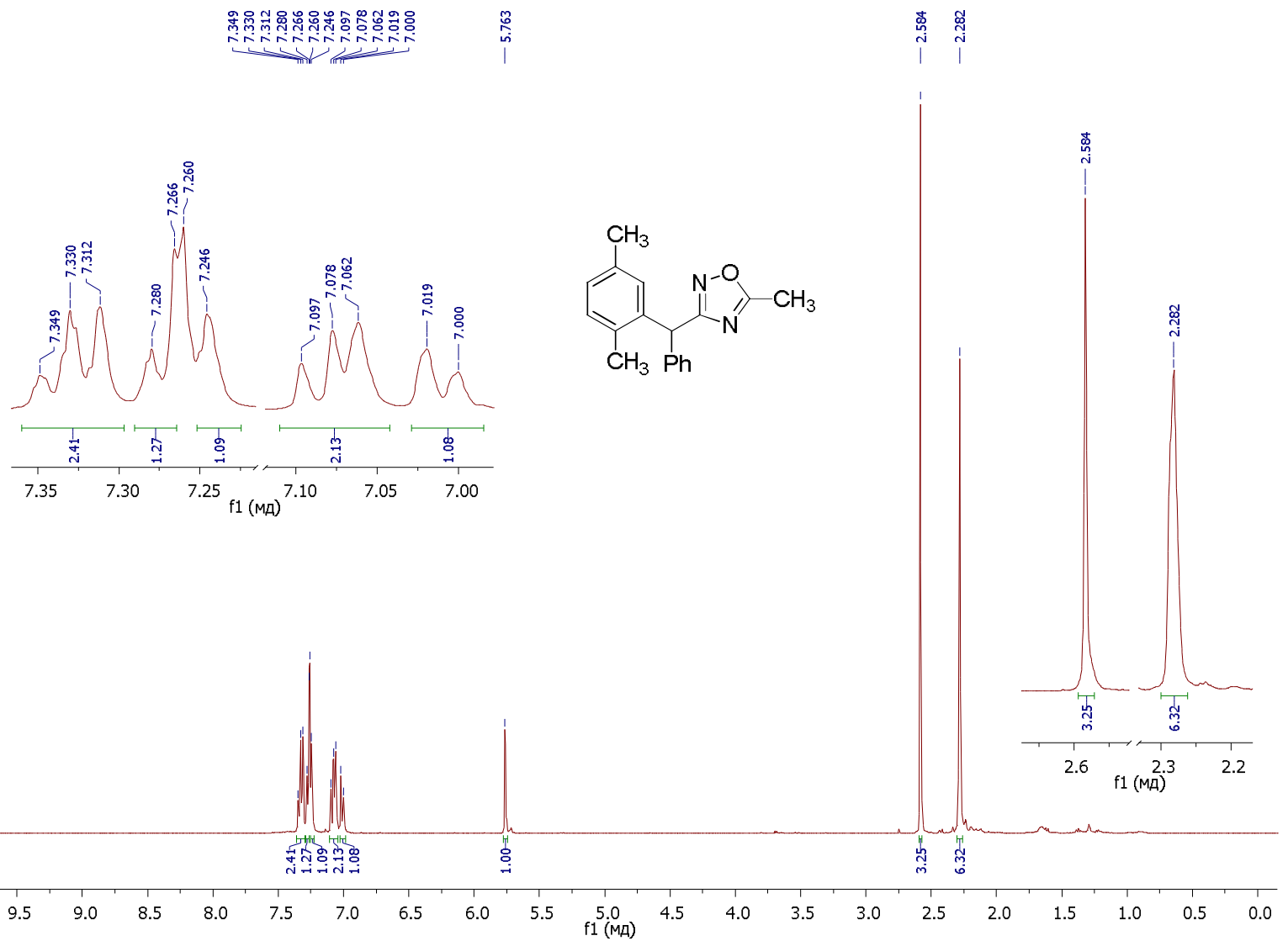

Fig. S52. ${ }^{1} \mathrm{H}$ NMR spectrum of the compound $2 \mathbf{r}\left(\mathrm{CDCl}_{3}, 400 \mathrm{MHz}\right)$. 


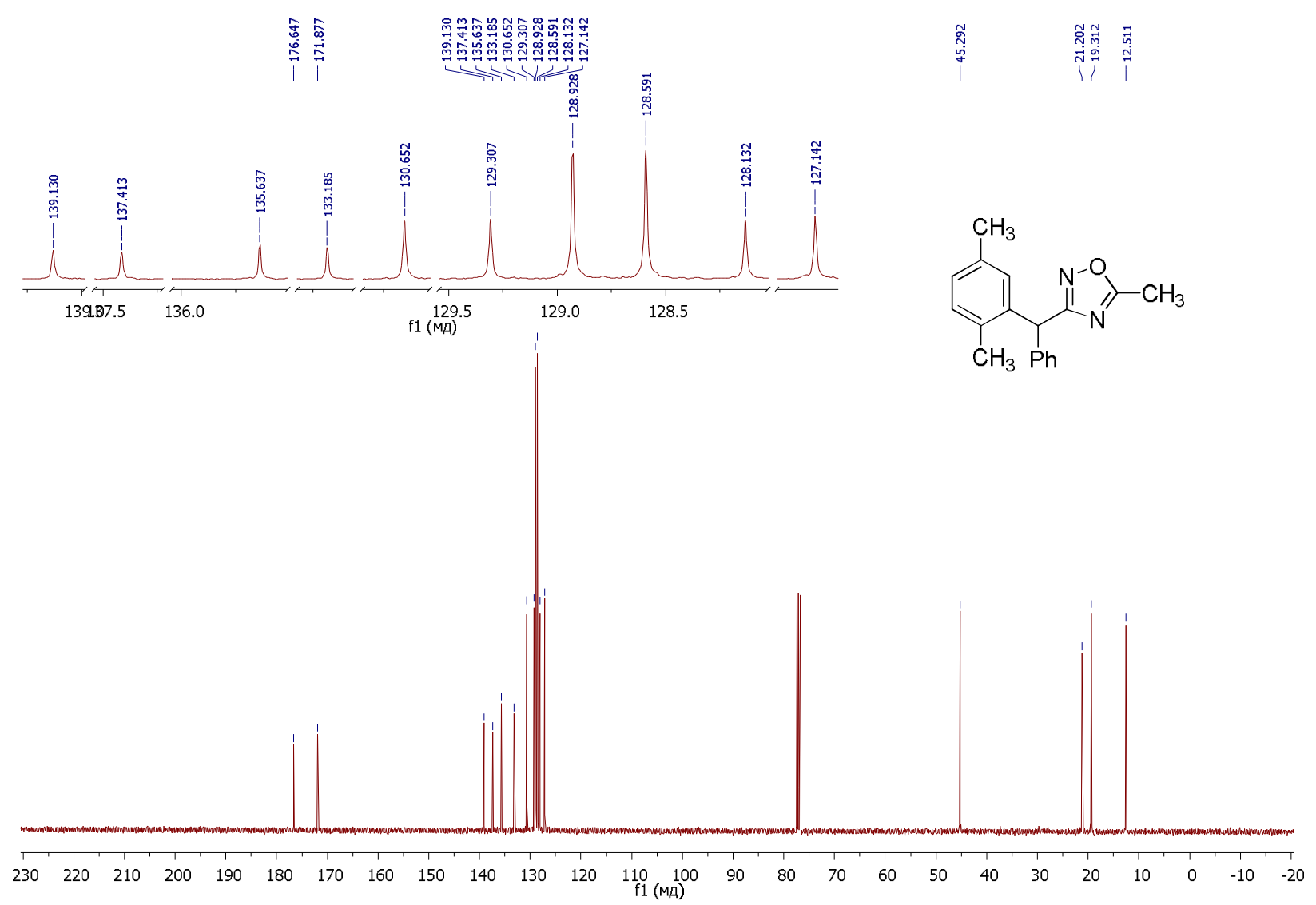

Fig. S53. ${ }^{13} \mathrm{C}\{\mathrm{H}\}$ NMR spectrum of the compound $2 \mathbf{r}\left(\mathrm{CDCl}_{3}, 101 \mathrm{MHz}\right)$.

๑ SHIMADZU

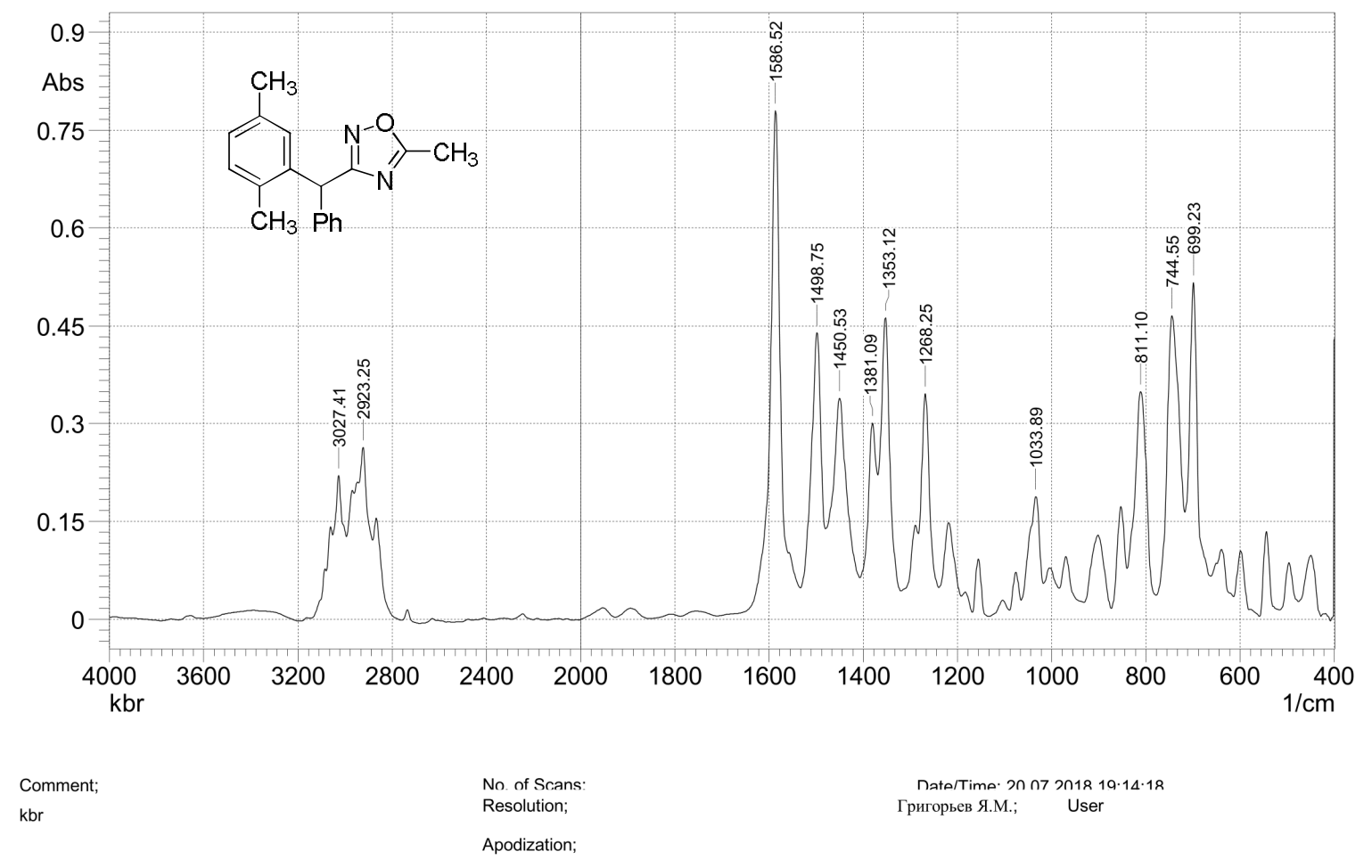

Fig. S54. IR spectrum of the compound $2 \mathbf{r}(\mathrm{KBr})$. 


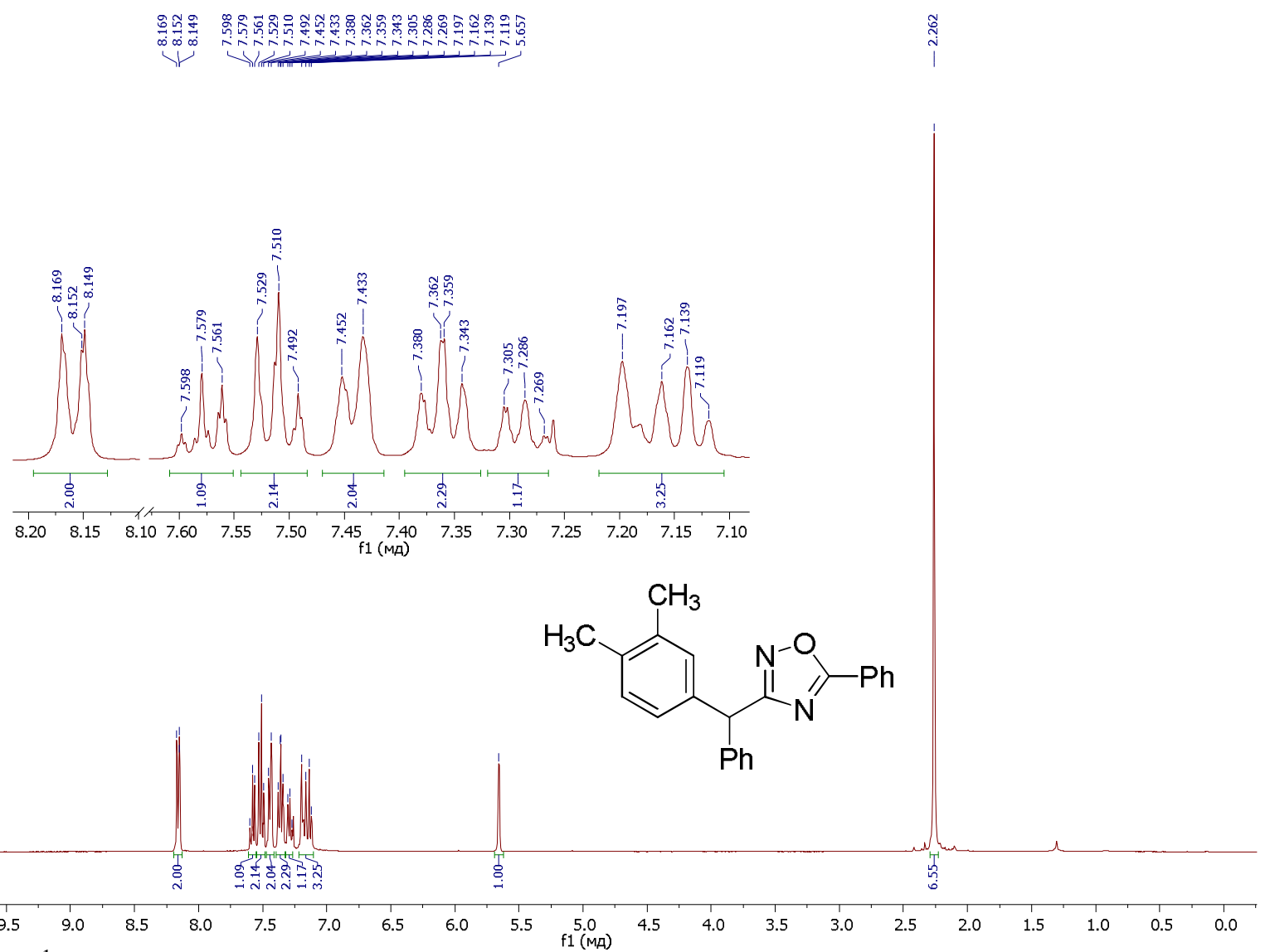

Fig. S55. ${ }^{1} \mathrm{H}$ NMR spectrum of the compound $2 \mathrm{~s}\left(\mathrm{CDCl}_{3}, 400 \mathrm{MHz}\right)$.
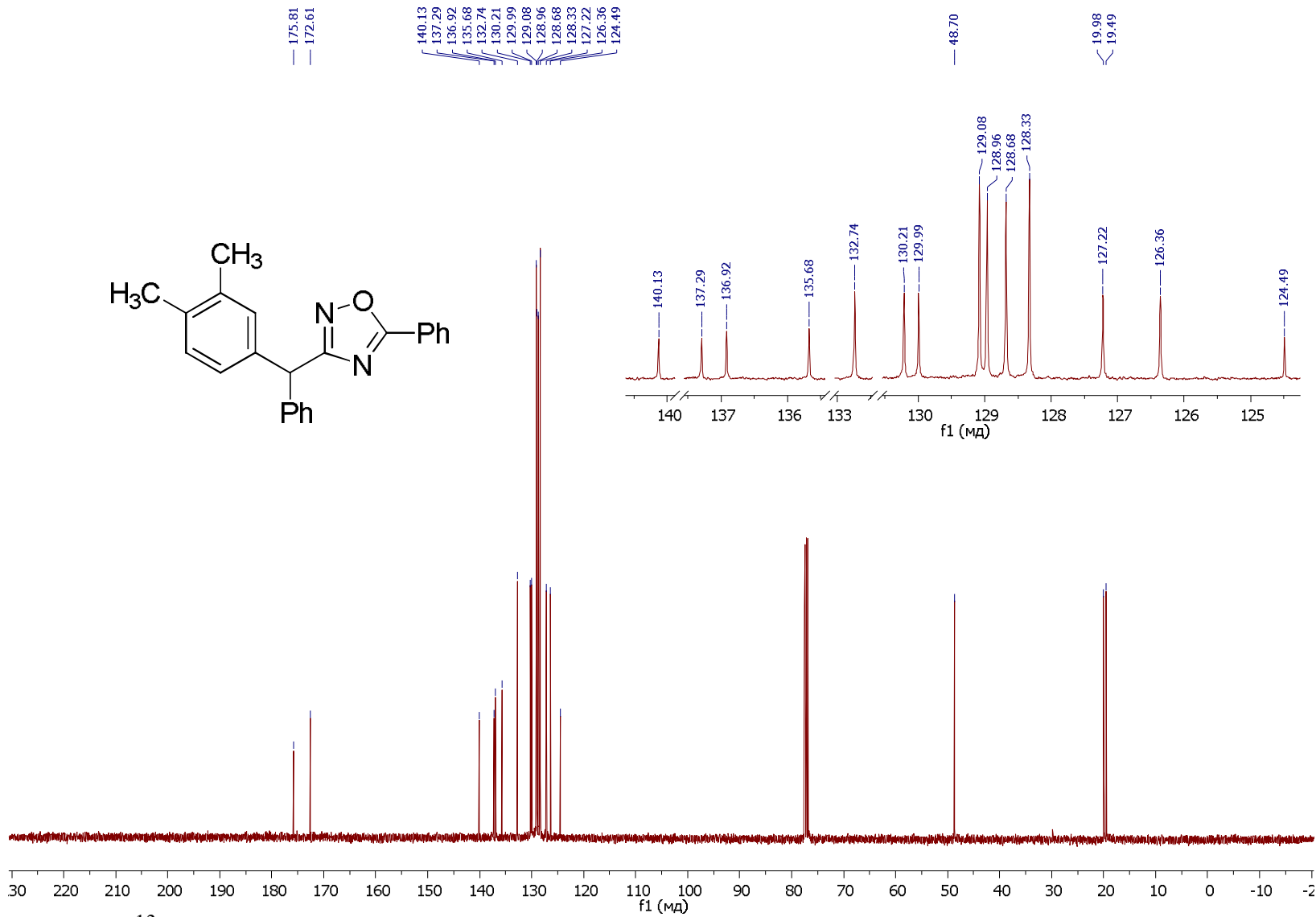

Fig. S56. ${ }^{13} \mathrm{C}\{\mathrm{H}\}$ NMR spectrum of the compound $2 \mathrm{~s}\left(\mathrm{CDCl}_{3}, 101 \mathrm{MHz}\right)$. 


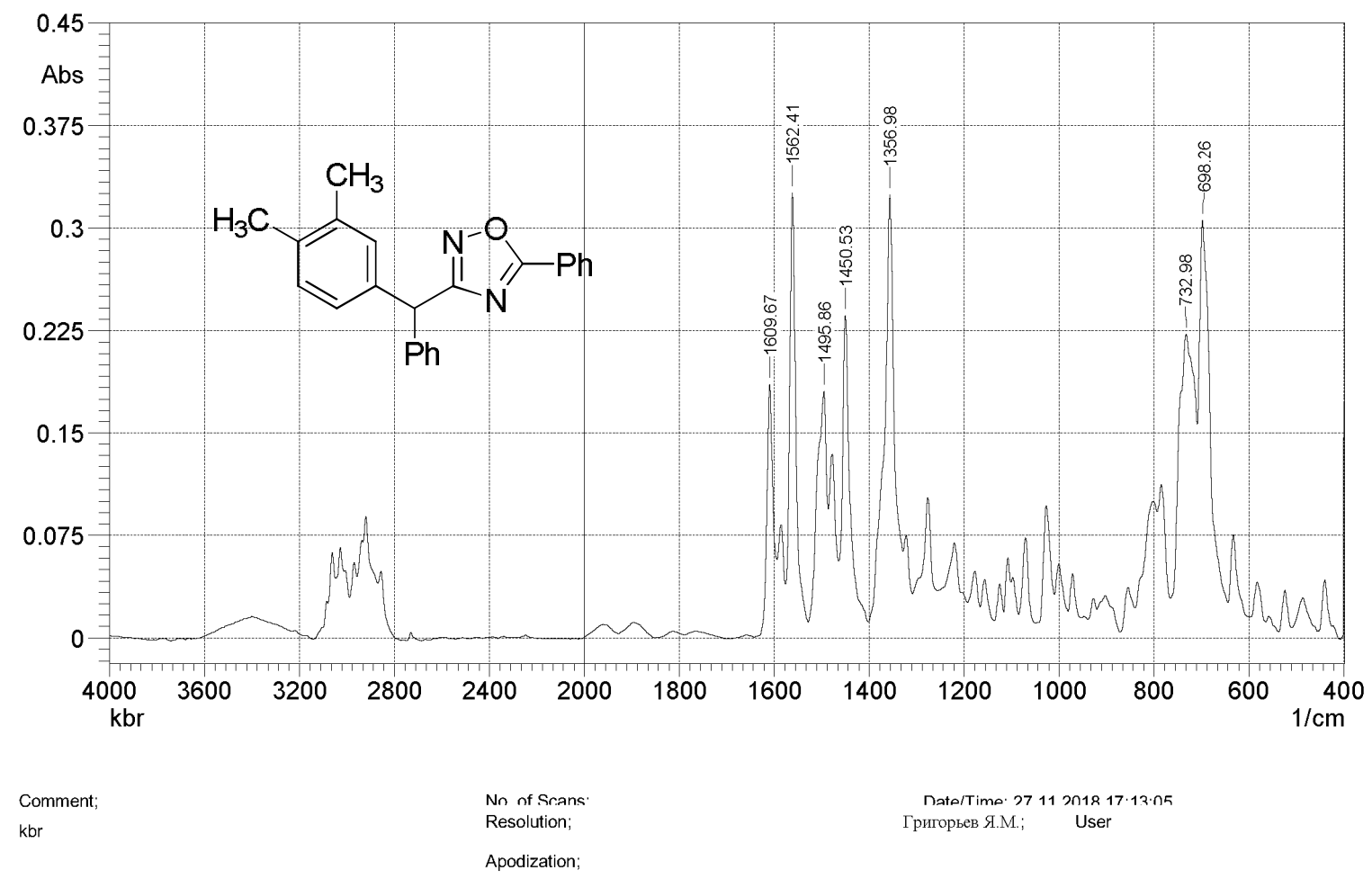

Fig. S57. IR spectrum of the compound $2 \mathbf{s}(\mathrm{KBr})$.
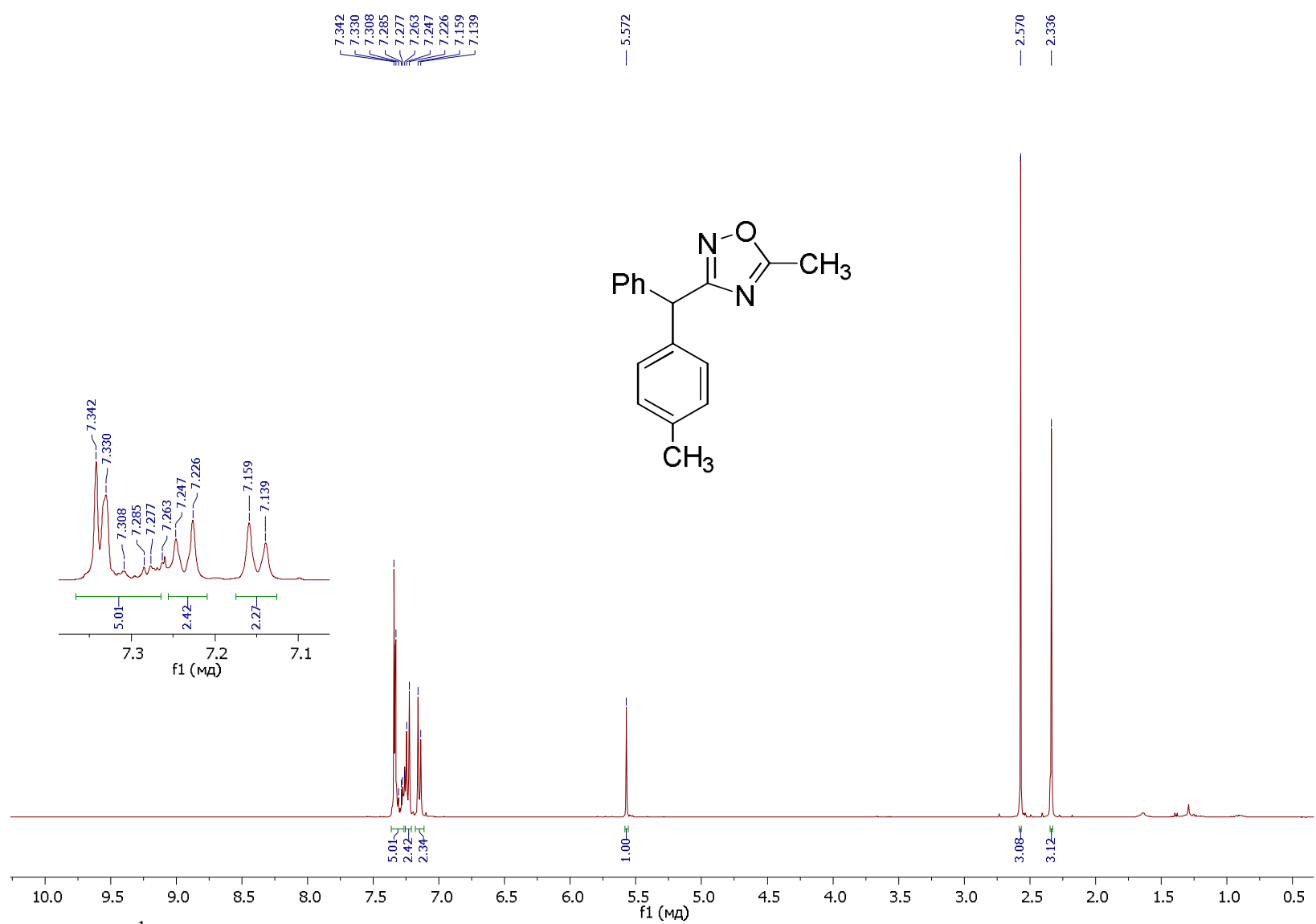

Fig. S58. ${ }^{1} \mathrm{H}$ NMR spectrum of the compound $2 \mathrm{t}\left(\mathrm{CDCl}_{3}, 400 \mathrm{MHz}\right)$. 


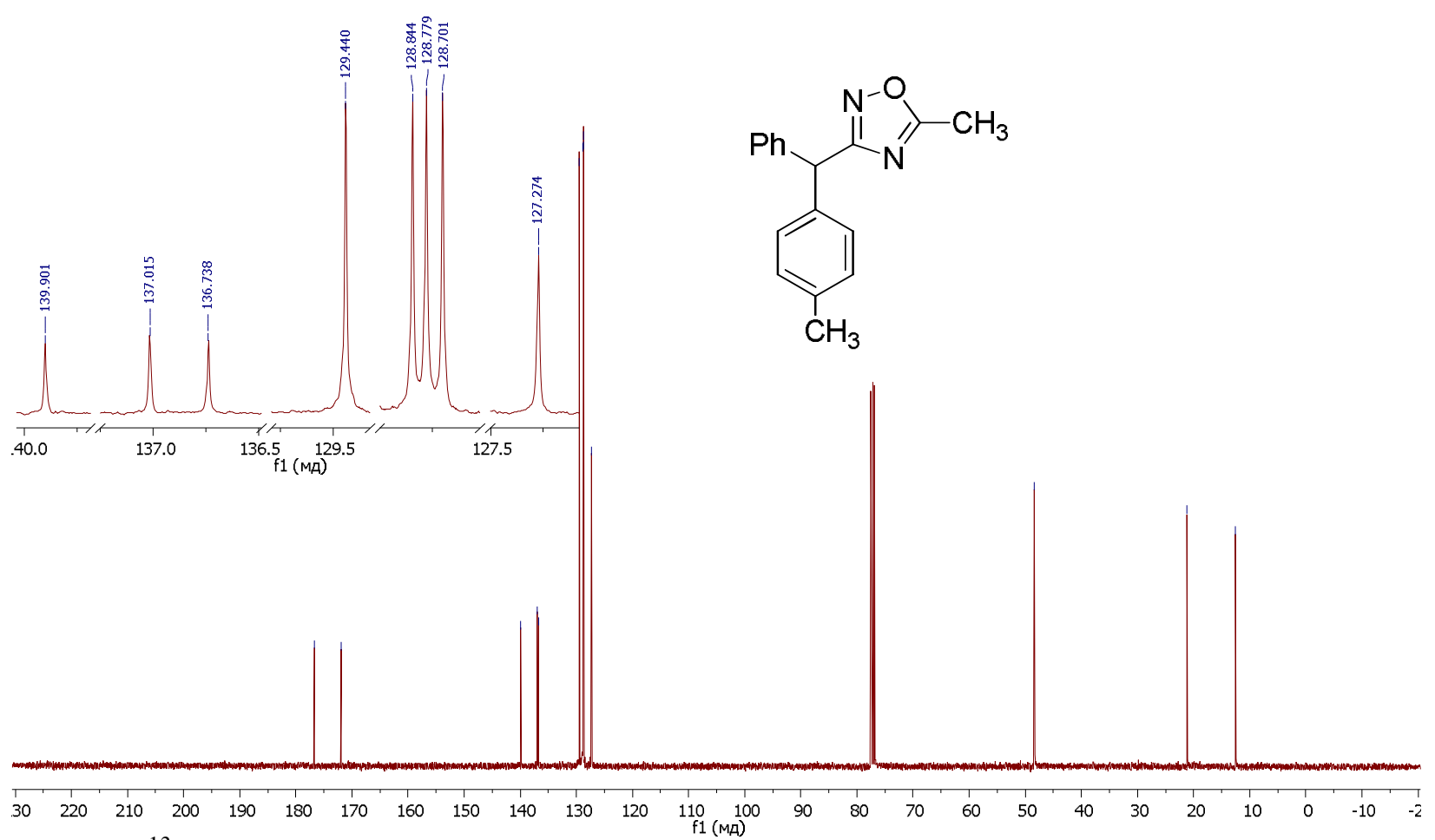

Fig. S59. ${ }^{13} \mathrm{C}\{\mathrm{H}\}$ NMR spectrum of the compound $2 \mathbf{t}\left(\mathrm{CDCl}_{3}, 101 \mathrm{MHz}\right)$.

ФSHIMADZu

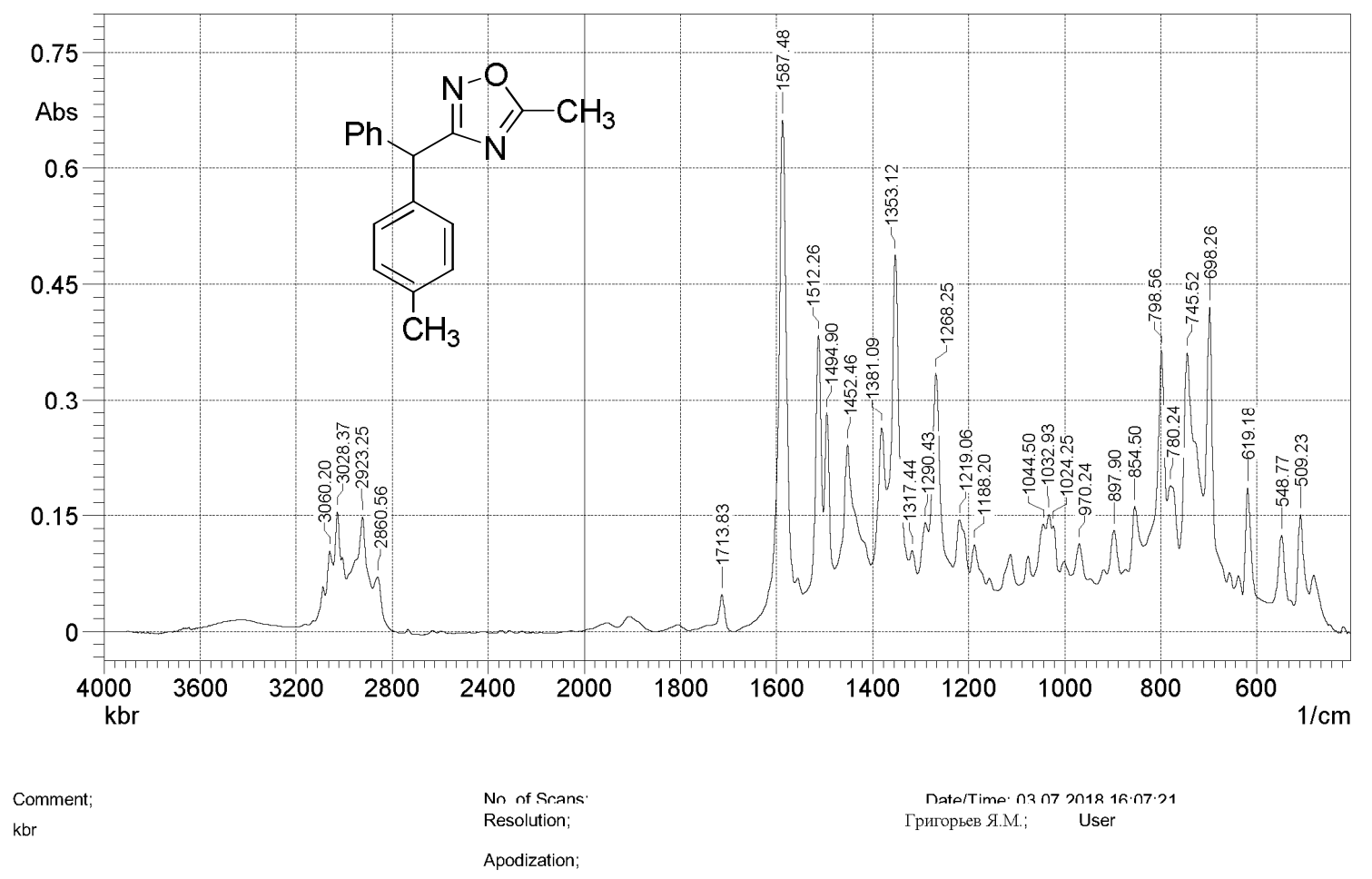

Fig. S60. IR spectrum of the compound $\mathbf{2 t}(\mathrm{KBr})$. 


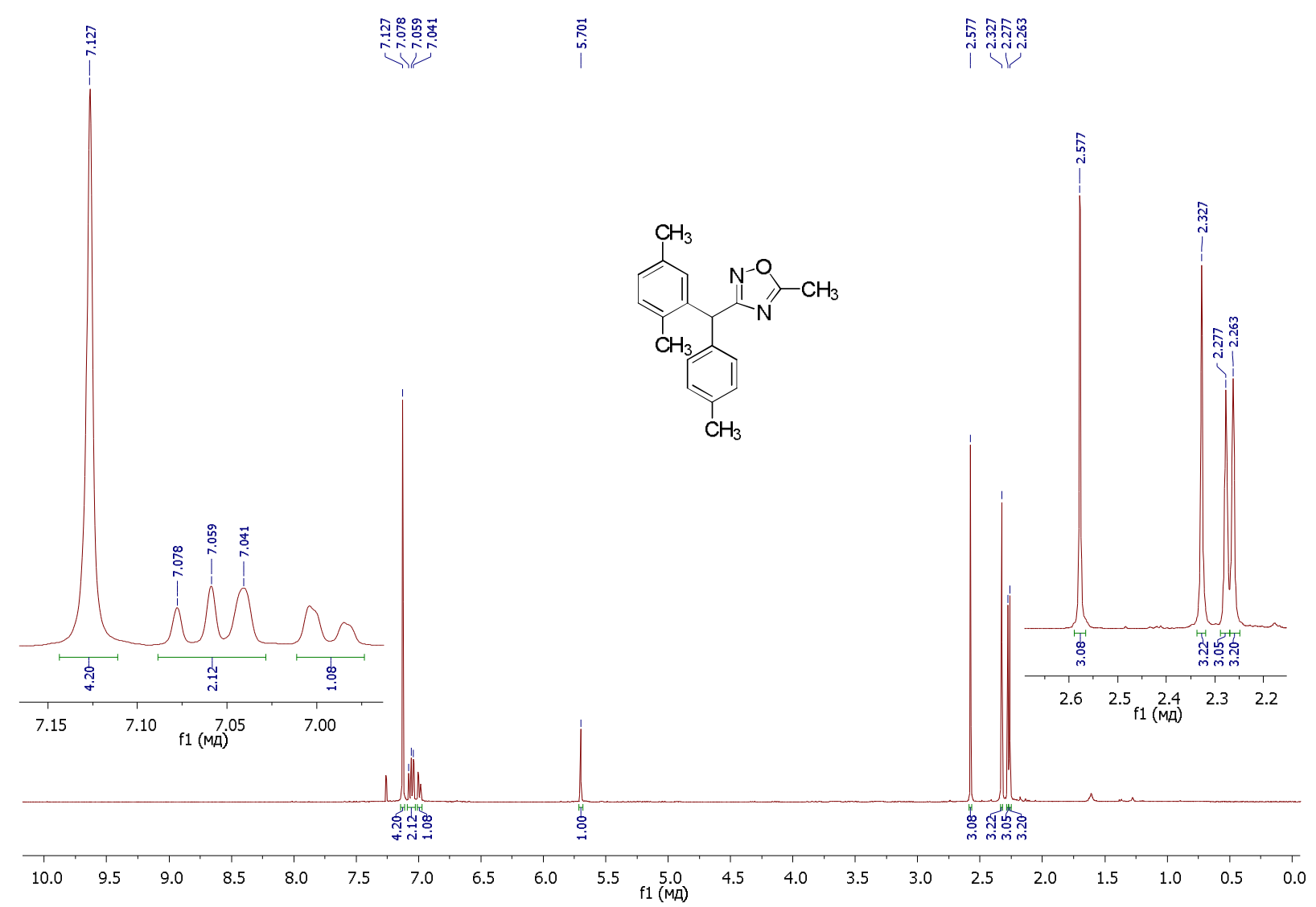

Fig. S61. ${ }^{1} \mathrm{H}$ NMR spectrum of the compound $\mathbf{2 u}\left(\mathrm{CDCl}_{3}, 400 \mathrm{MHz}\right)$.

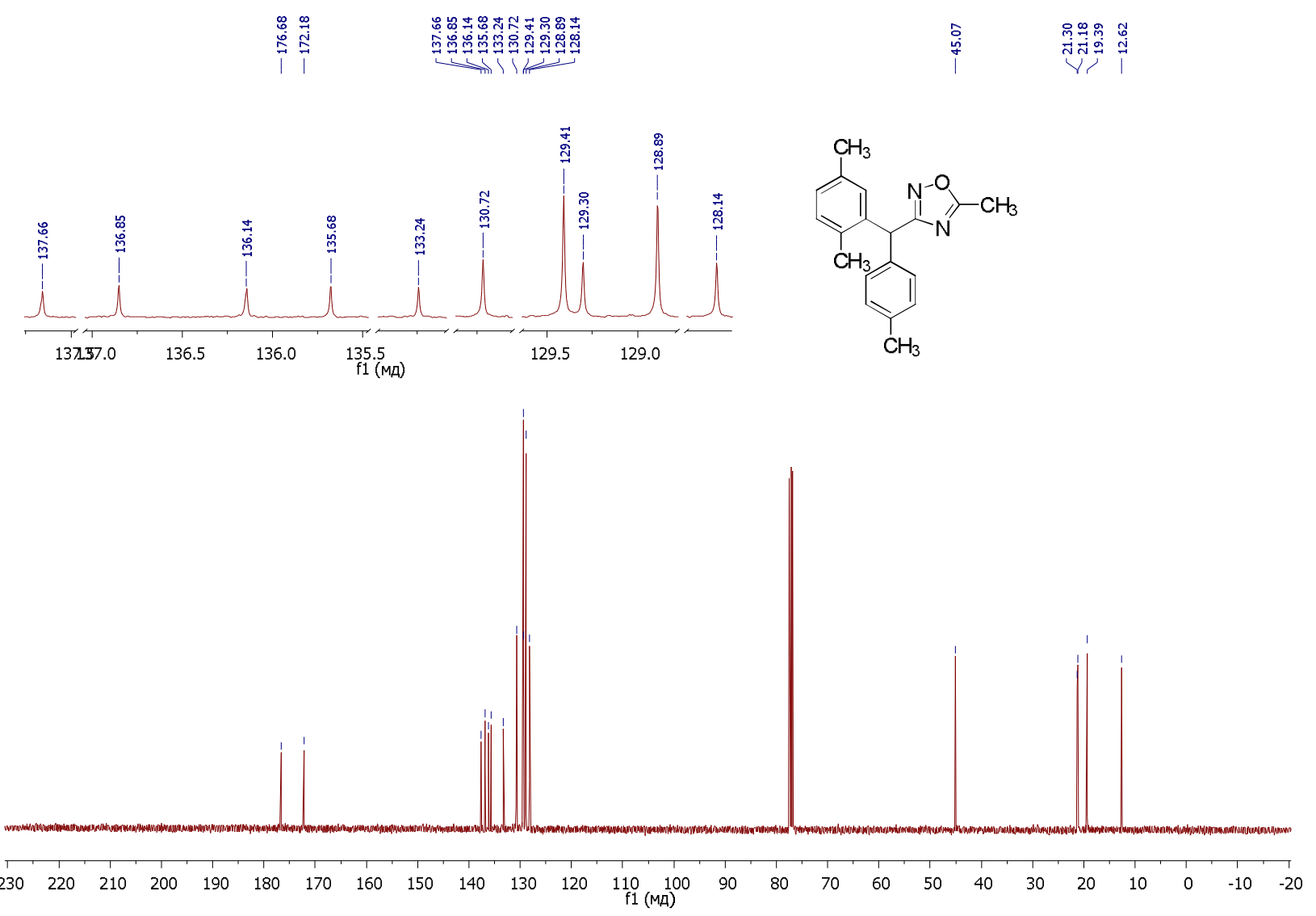

Fig. S62. ${ }^{13} \mathrm{C}\{\mathrm{H}\}$ NMR spectrum of the compound $\mathbf{2 u}\left(\mathrm{CDCl}_{3}, 101 \mathrm{MHz}\right)$. 


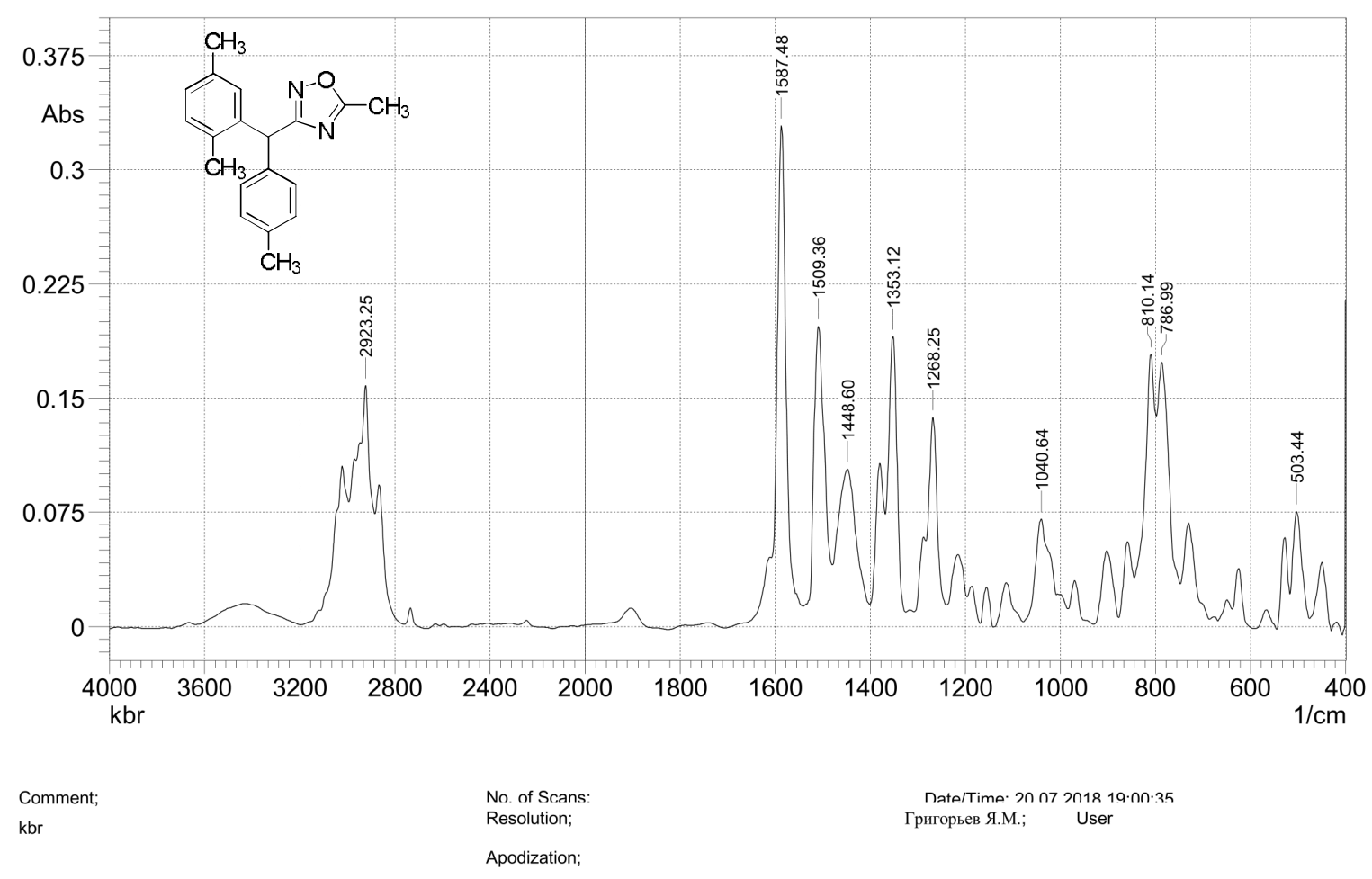

Fig. S63. IR spectrum of the compound $\mathbf{2 u}(\mathrm{KBr})$.
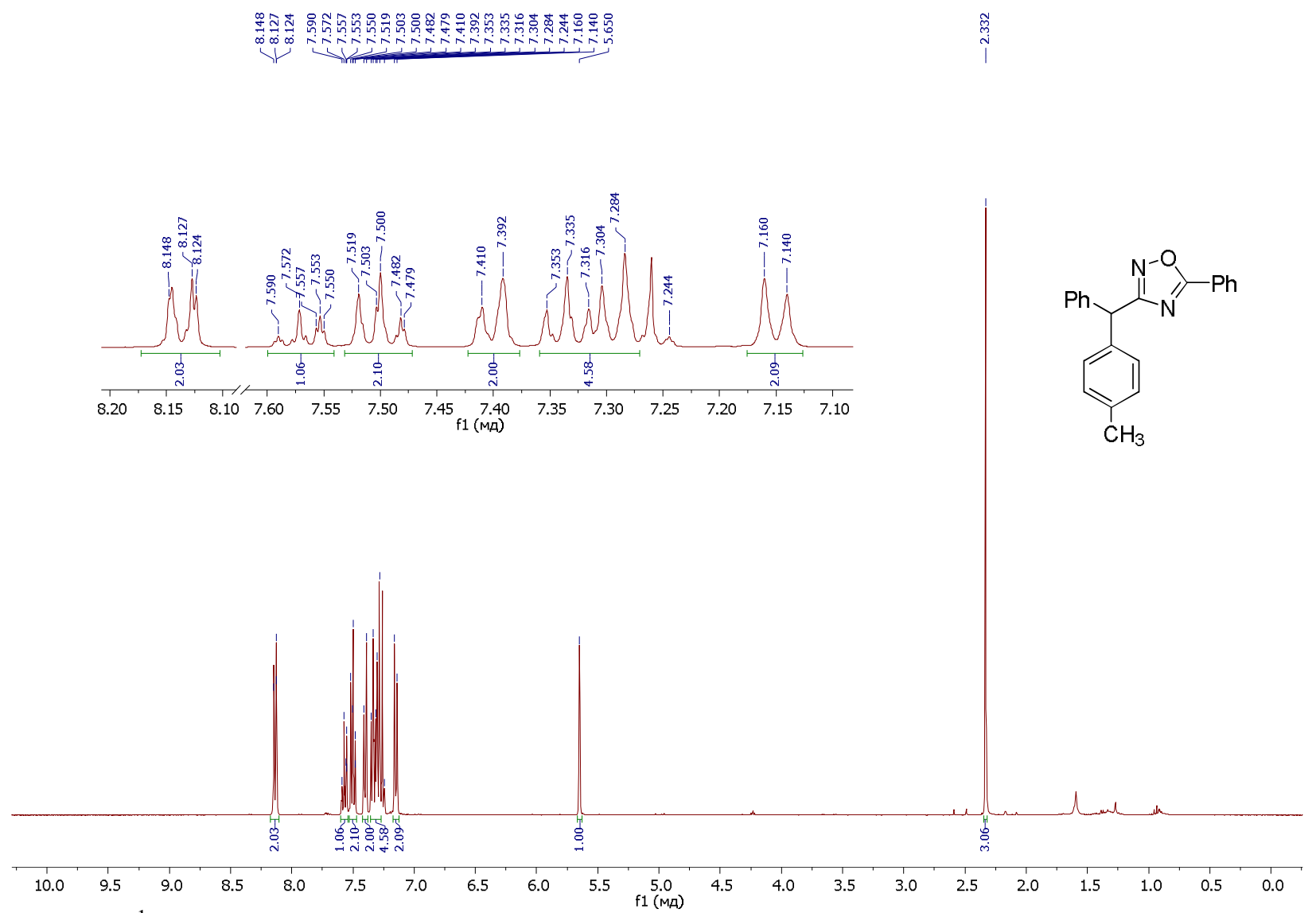

Fig. S64. ${ }^{1} \mathrm{H}$ NMR spectrum of the compound $\mathbf{2 v}\left(\mathrm{CDCl}_{3}, 400 \mathrm{MHz}\right)$. 


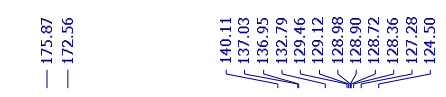
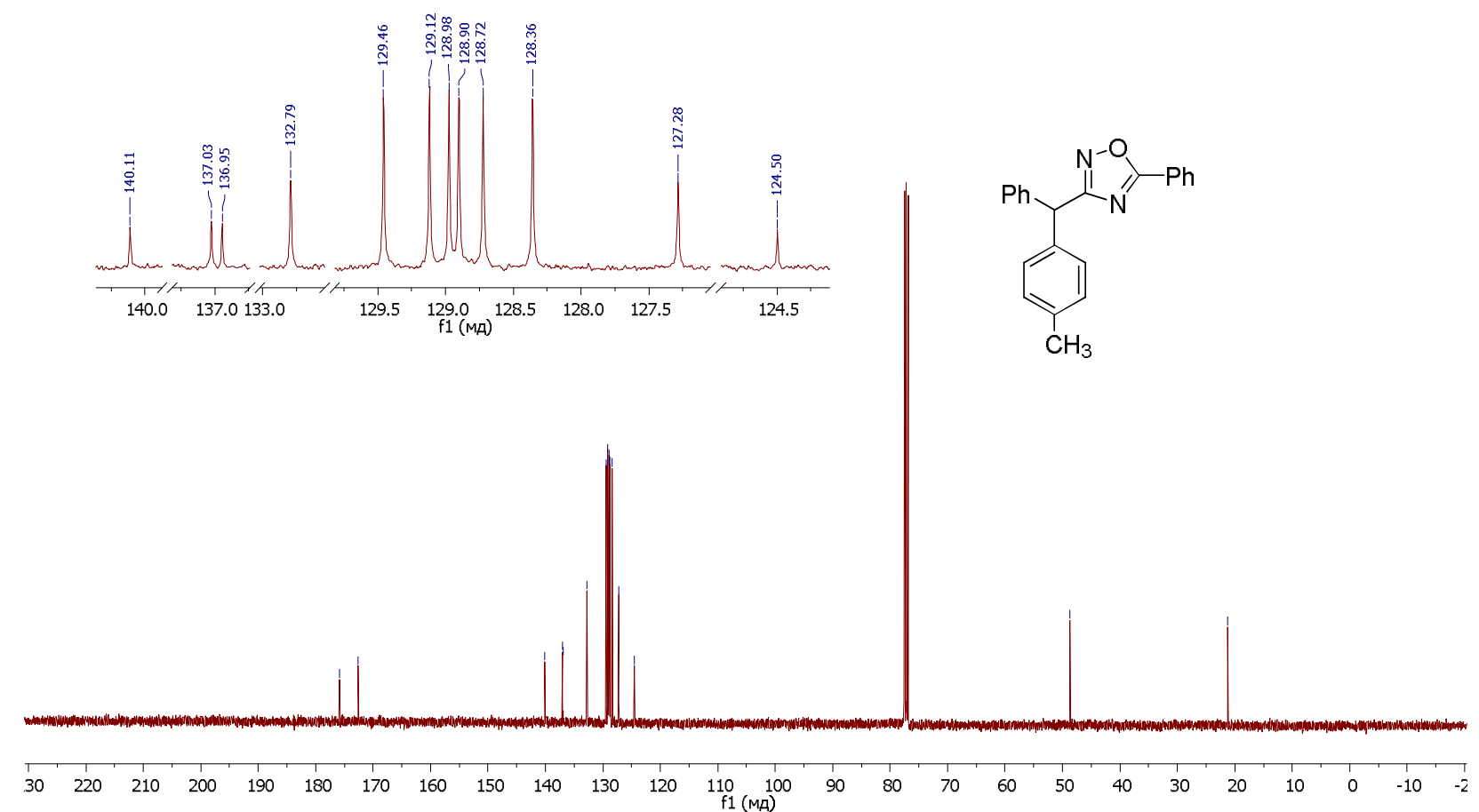

Fig. S65. ${ }^{13} \mathrm{C}\{\mathrm{H}\}$ NMR spectrum of the compound $\mathbf{2 v}\left(\mathrm{CDCl}_{3}, 101 \mathrm{MHz}\right)$.

ФSHIMADZU

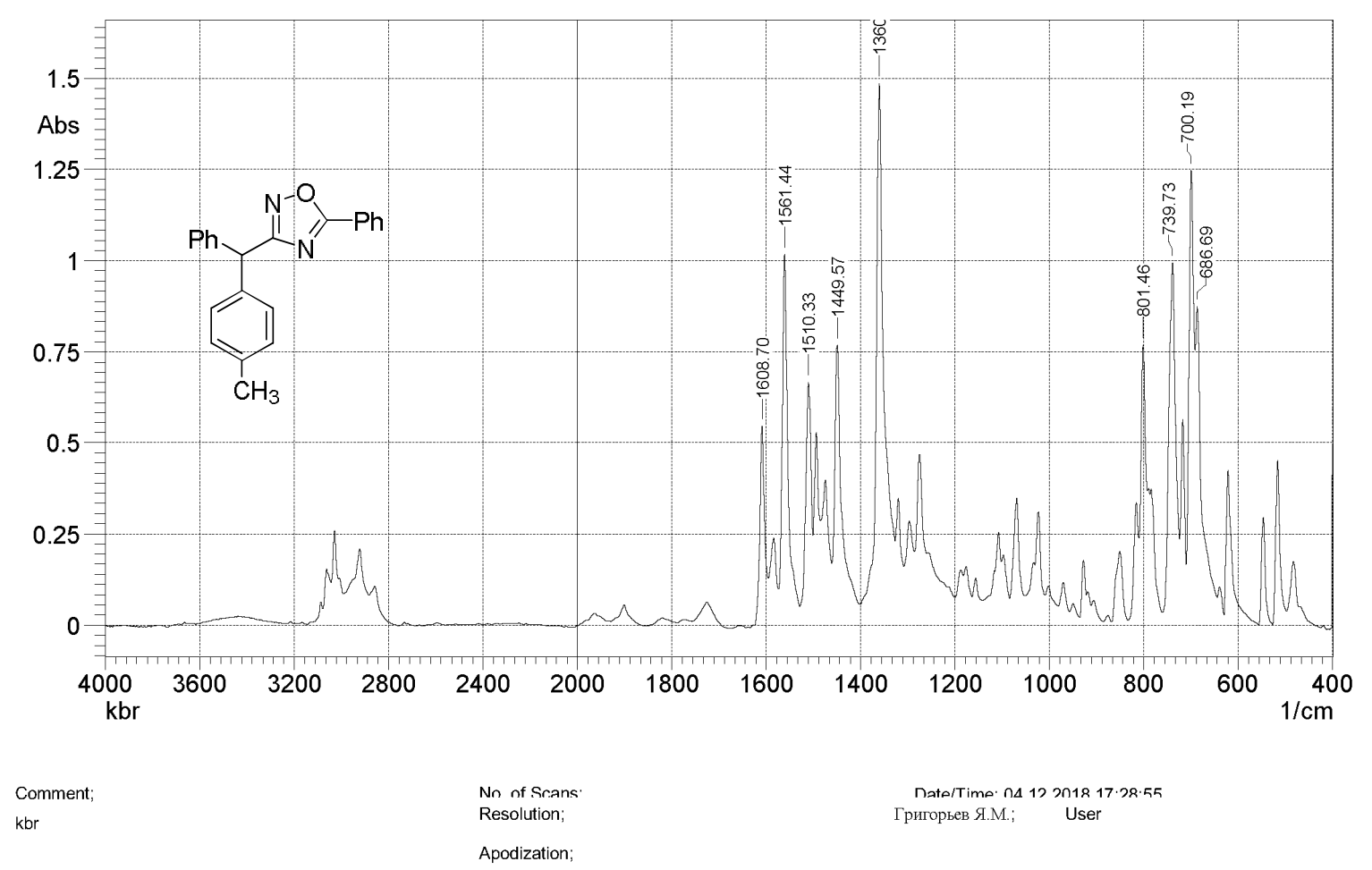

Fig. S66. IR spectrum of the compound $2 \mathbf{v}(\mathrm{KBr})$. 


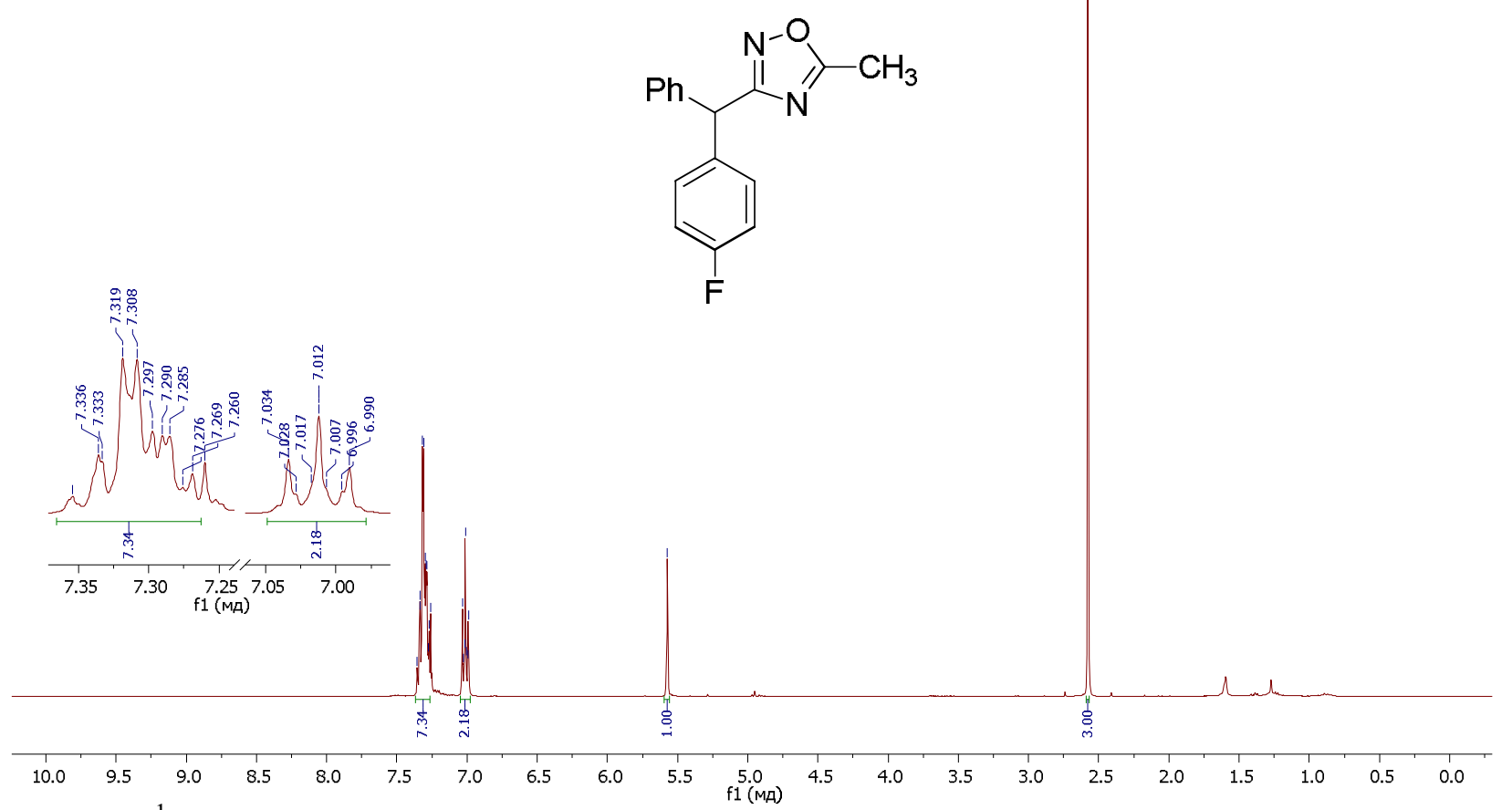

Fig. S67. ${ }^{1} \mathrm{H}$ NMR spectrum of the compound $\mathbf{2} \mathbf{w}\left(\mathrm{CDCl}_{3}, 400 \mathrm{MHz}\right)$.

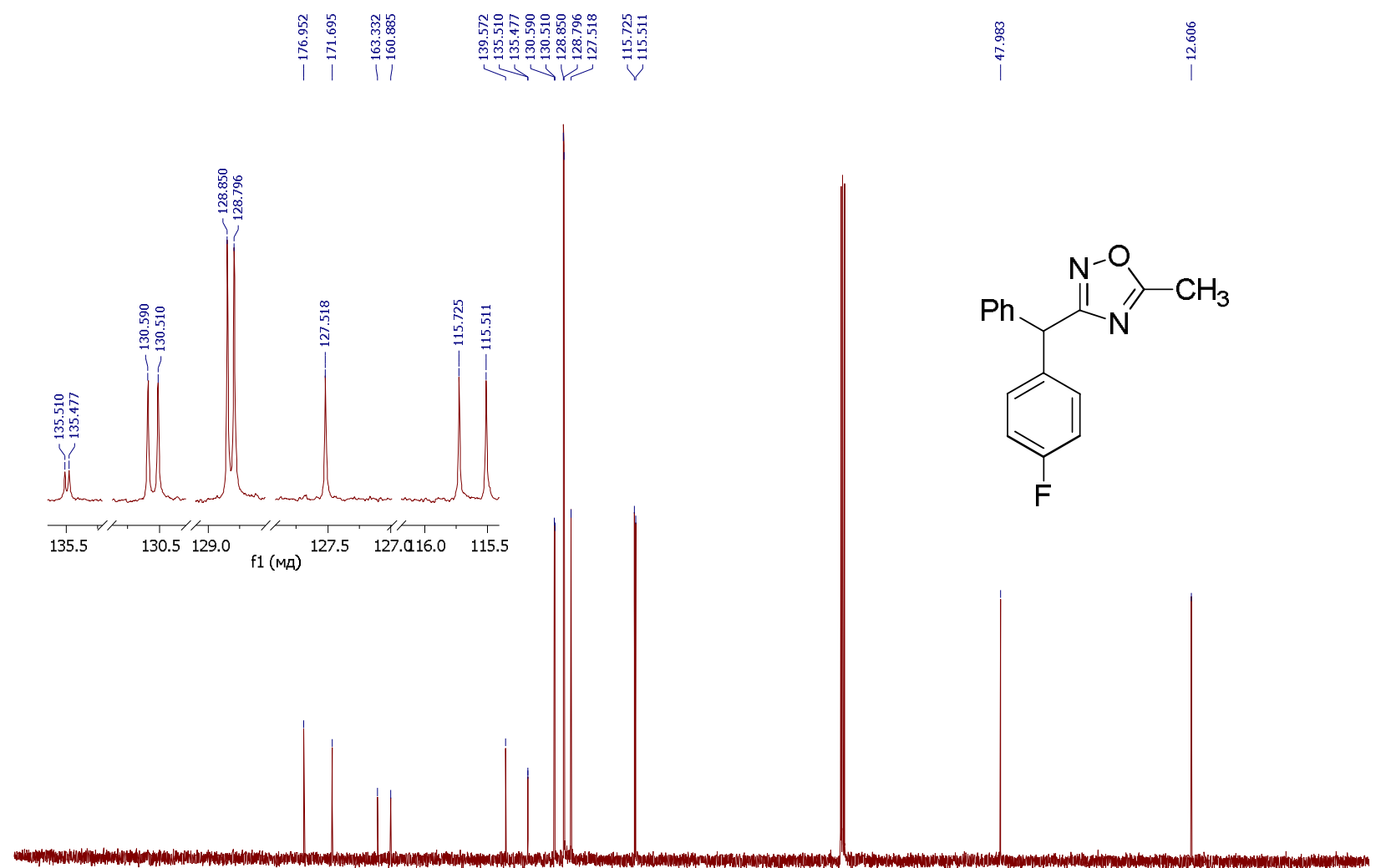

$\begin{array}{lllllllllllllllllllllllllllllllllllll}3 & 220 & 210 & 200 & 190 & 180 & 170 & 160 & 150 & 140 & 130 & 120 & 110 & 100 & 90 & 80 & 70 & 60 & 50 & 40 & 30 & 20 & 10 & 0 & -10 & -2\end{array}$

Fig. S68. ${ }^{13} \mathrm{C}\{\mathrm{H}\}$ NMR spectrum of the compound $\mathbf{2 w}\left(\mathrm{CDCl}_{3}, 101 \mathrm{MHz}\right)$ 


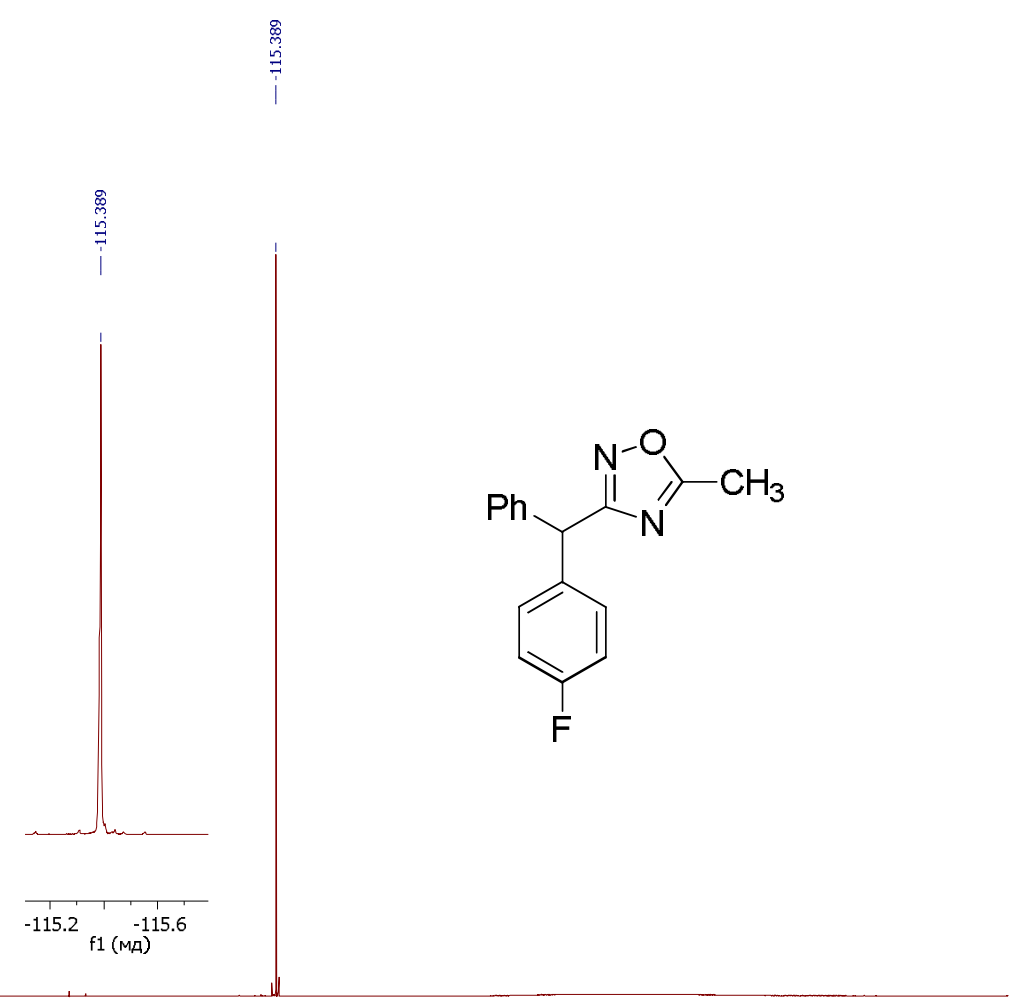

$\begin{array}{lllllllllllllllllllllllllllllllllllllll}50 & 40 & 30 & 20 & 10 & 0 & -10 & -20 & -30 & -40 & -50 & -60 & -70 & -80 & -90 & -100 & -110 & -120 & -130 & -140 & -150 & -160 & -170 & -180 & -190 & -200 & -210 & -220 & -230 & -240 & -250\end{array}$ Fig. S69. ${ }^{19} \mathrm{~F}\{\mathrm{H}\}$ NMR spectrum of the compound $\mathbf{2 w}\left(\mathrm{CDCl}_{3}, 376 \mathrm{MHz}\right)$.

ФSHIMADZU

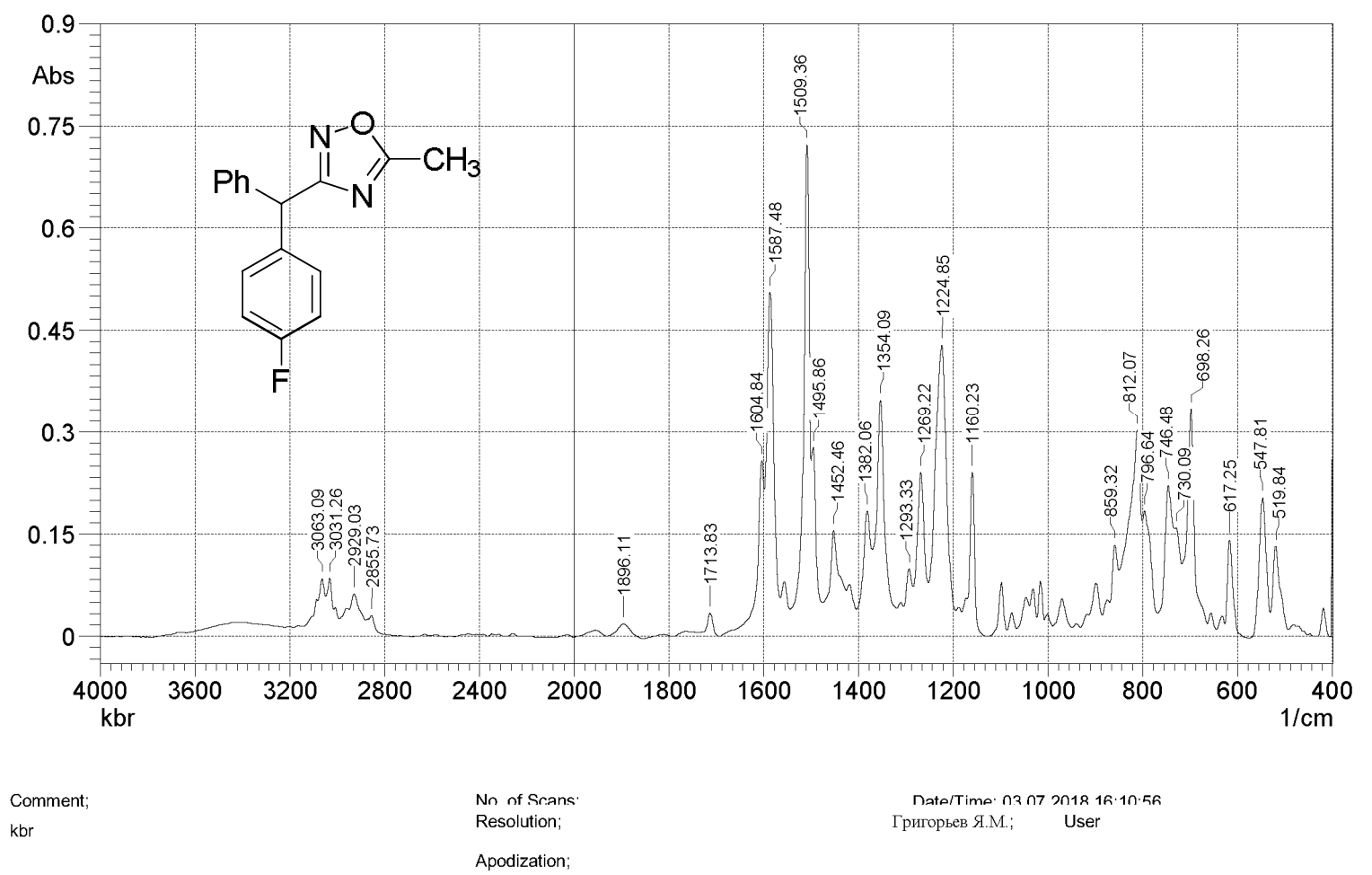

Fig. S70. IR spectrum of the compound $\mathbf{2 w}(\mathrm{KBr})$. 


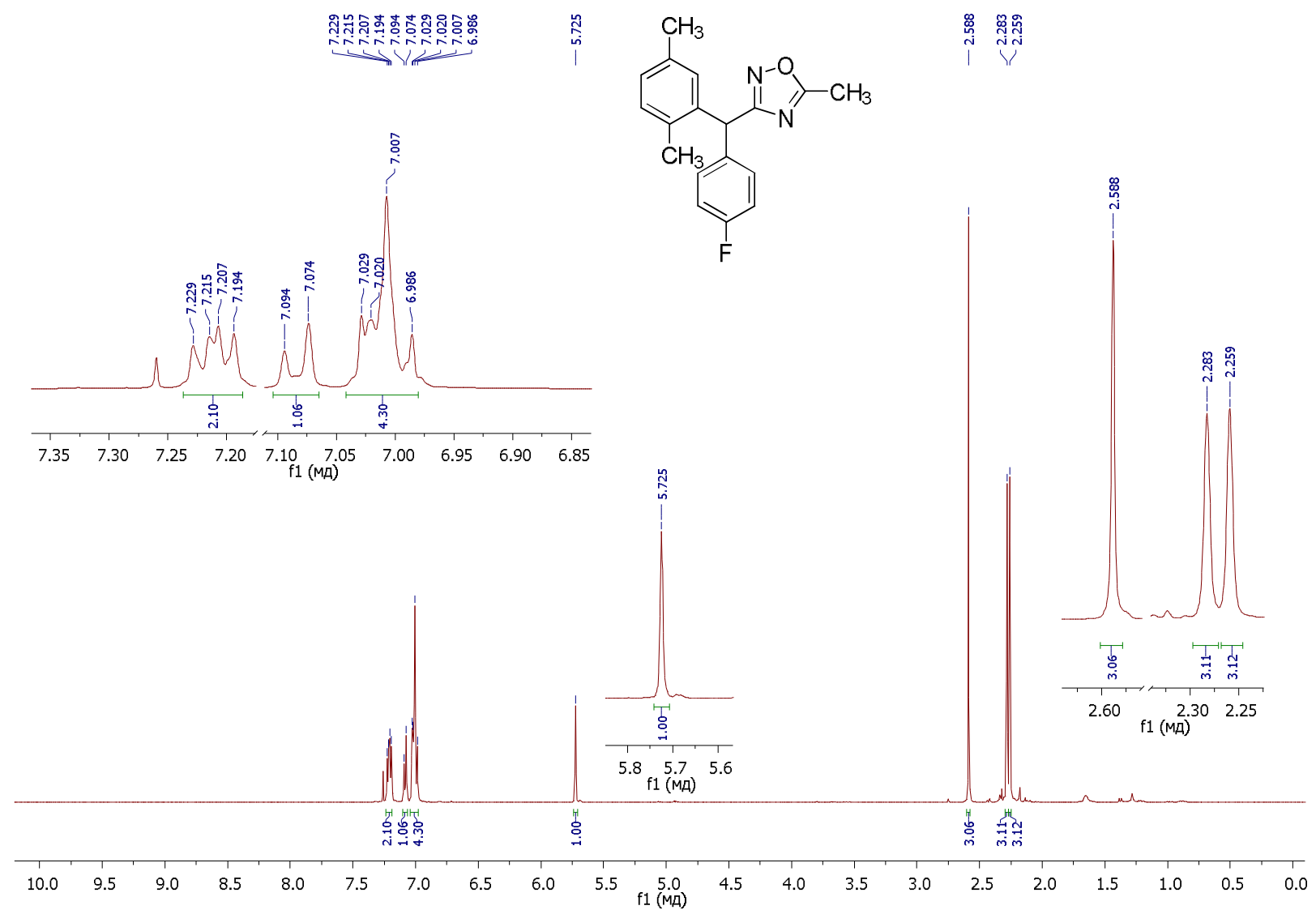

Fig. S71. ${ }^{1} \mathrm{H}$ NMR spectrum of the compound $\mathbf{2 x}\left(\mathrm{CDCl}_{3}, 400 \mathrm{MHz}\right)$.

| ।
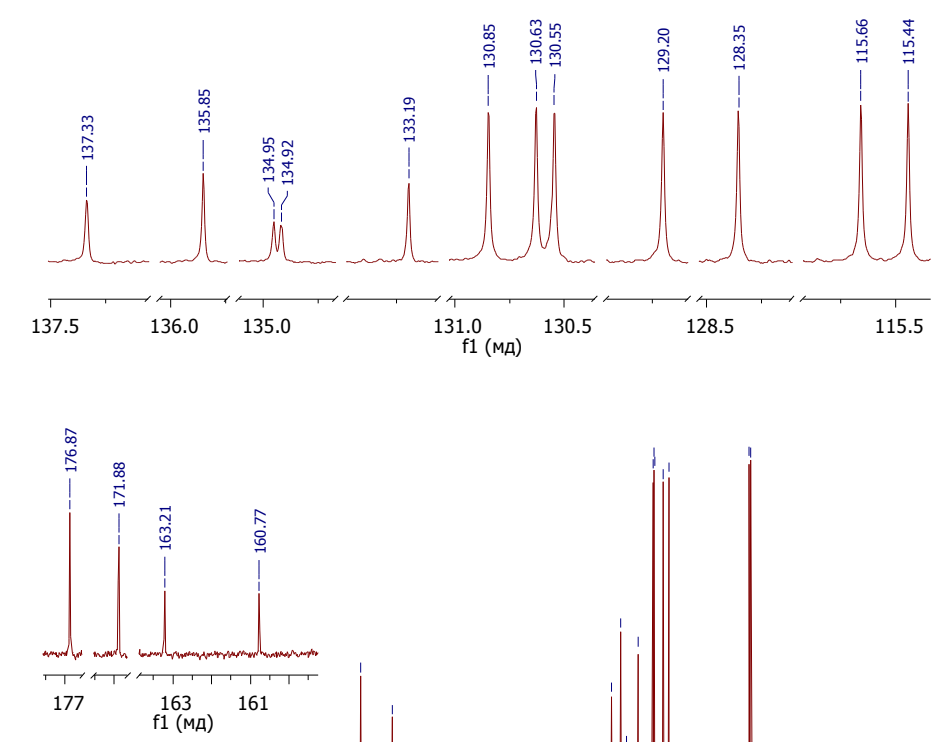

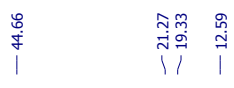

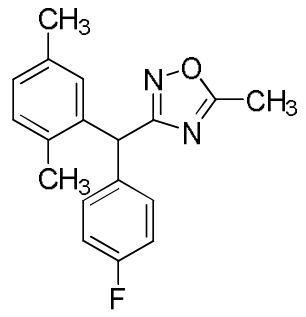

Fig. S72. ${ }^{13} \mathrm{C}\{\mathrm{H}\}$ NMR spectrum of the compound $2 \mathbf{x}\left(\mathrm{CDCl}_{3}, 101 \mathrm{MHz}\right)$. 


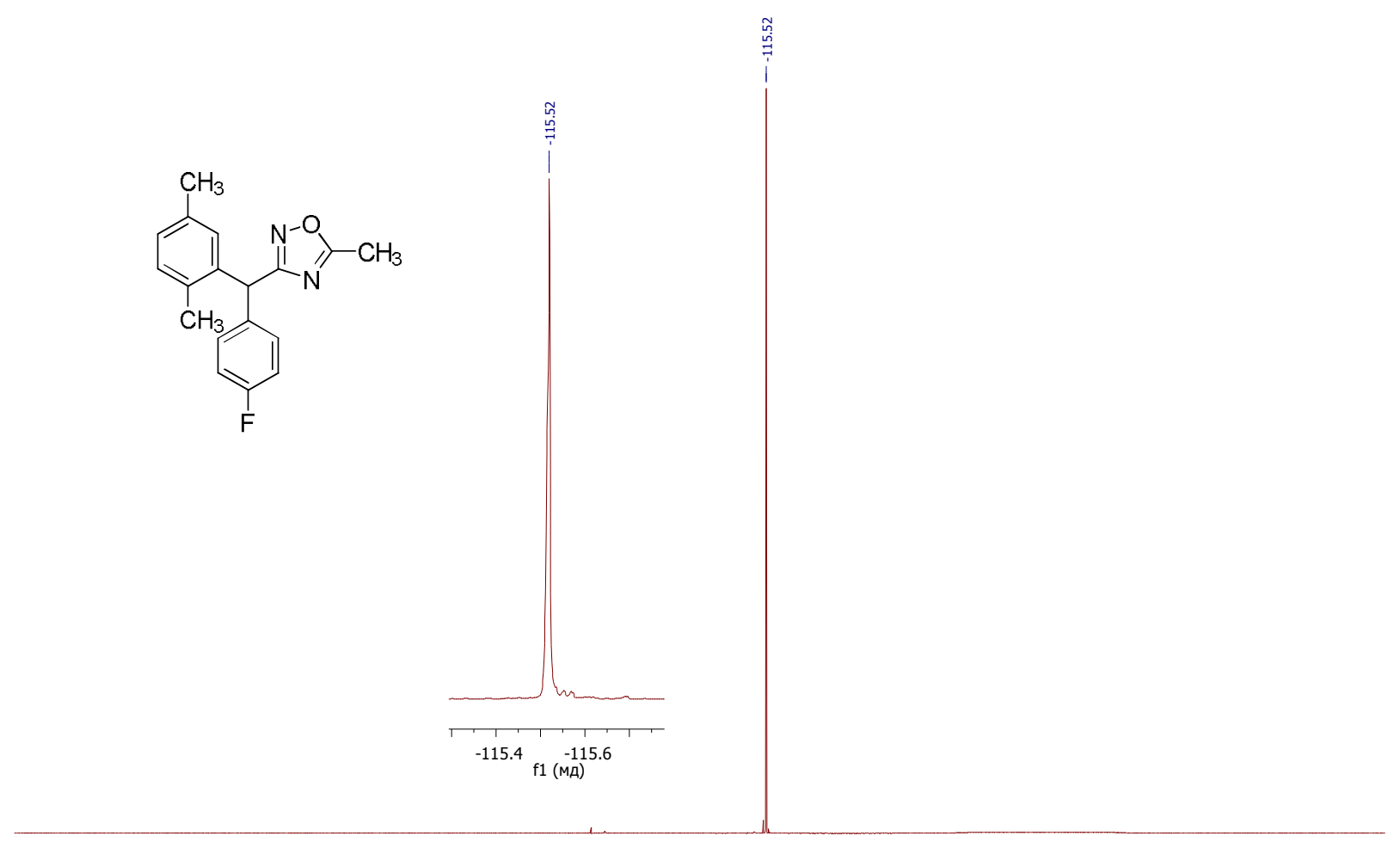

$\begin{array}{llllllllllllllllllllllllll}50 & 40 & 30 & 20 & 10 & 0 & -10 & -20 & -30 & -40 & -50 & -60 & -70 & -80 & -90 & -100 & -120 & -140 & -160 & -180 & -200 & -220 & -240 & \mathrm{f} 1 \text { (MA) } & & \end{array}$

Fig. S73. ${ }^{19} \mathrm{~F}\{\mathrm{H}\}$ NMR spectrum of the compound $2 \times\left(\mathrm{CDCl}_{3}, 376 \mathrm{MHz}\right)$.

ФSHIMADZU

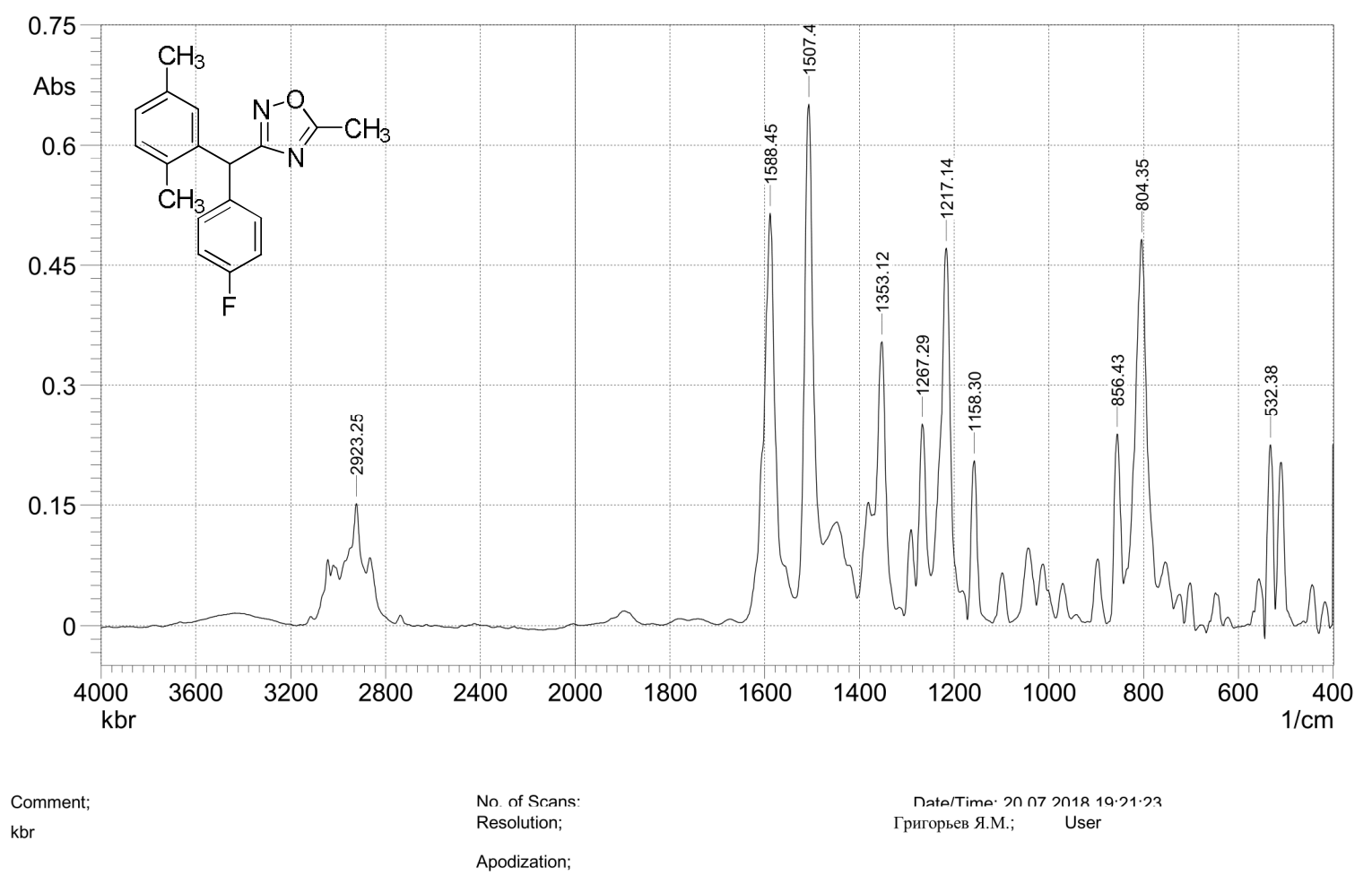

Fig. S74. IR spectrum of the compound $2 \mathbf{x}(\mathrm{KBr})$. 


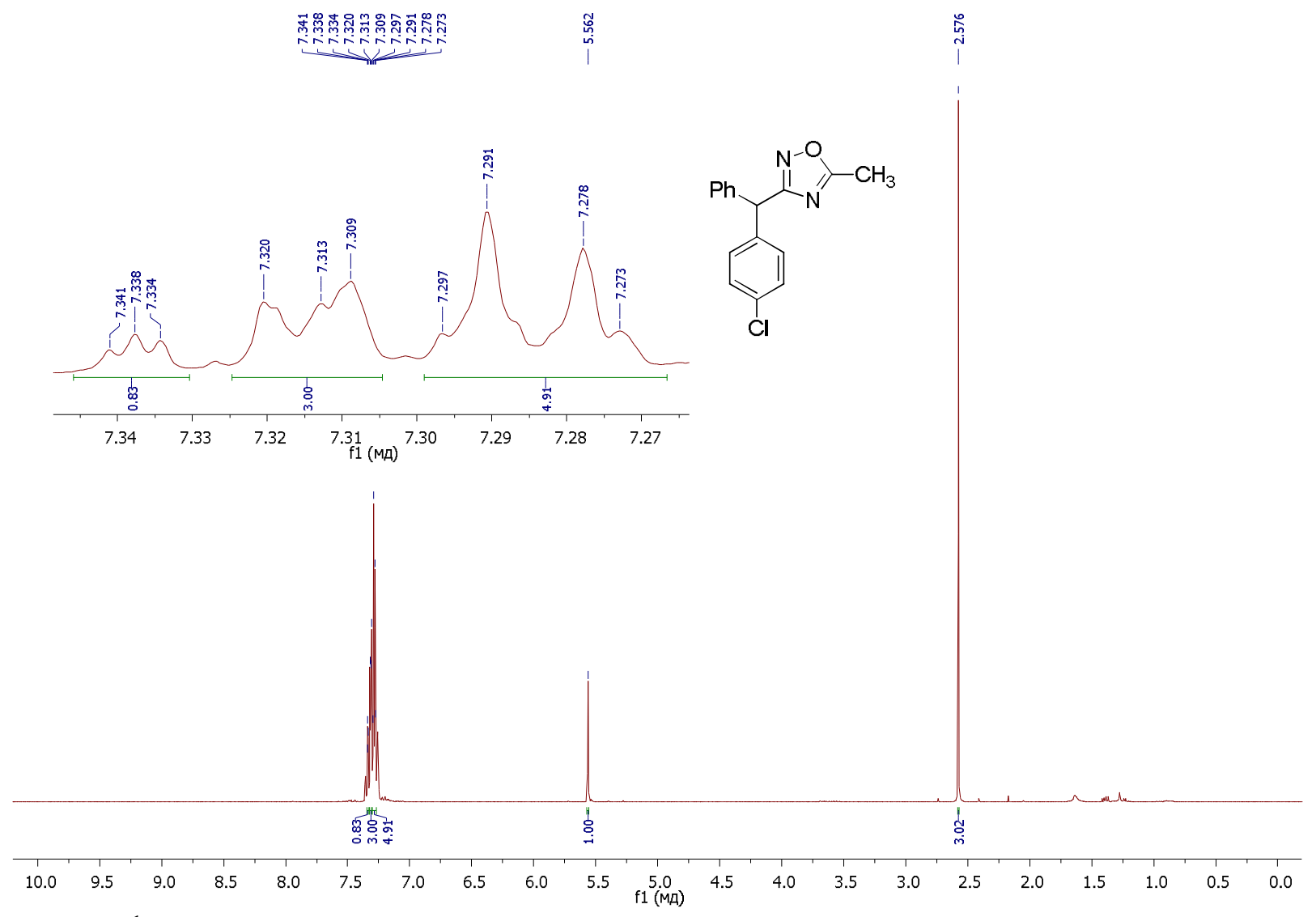

Fig. S75. ${ }^{1} \mathrm{H}$ NMR spectrum of the compound $2 \mathbf{y}\left(\mathrm{CDCl}_{3}, 400 \mathrm{MHz}\right)$.

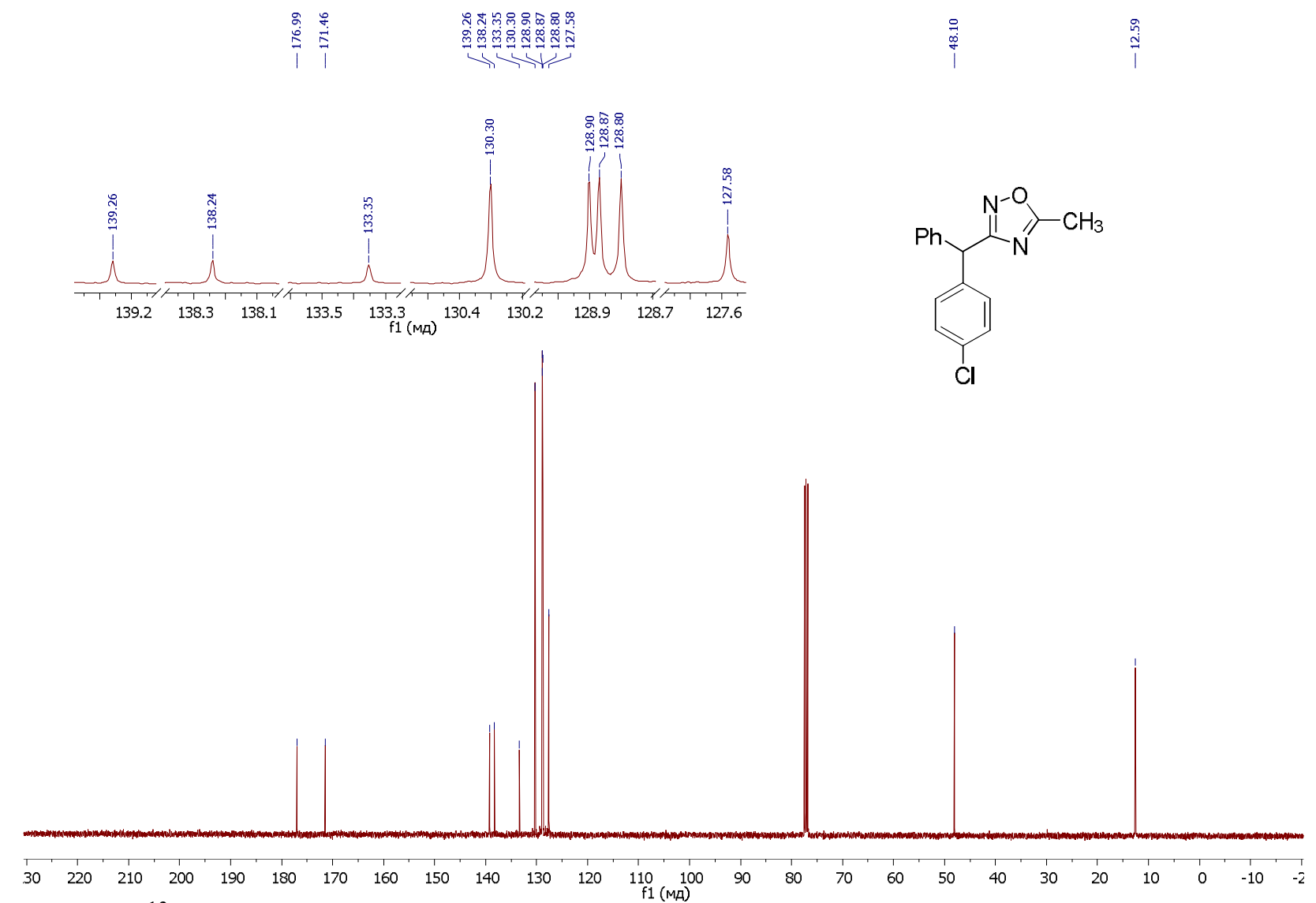

Fig. S76. ${ }^{13} \mathrm{C}\{\mathrm{H}\}$ NMR spectrum of the compound $\mathbf{2 y}\left(\mathrm{CDCl}_{3}, 101 \mathrm{MHz}\right)$. 


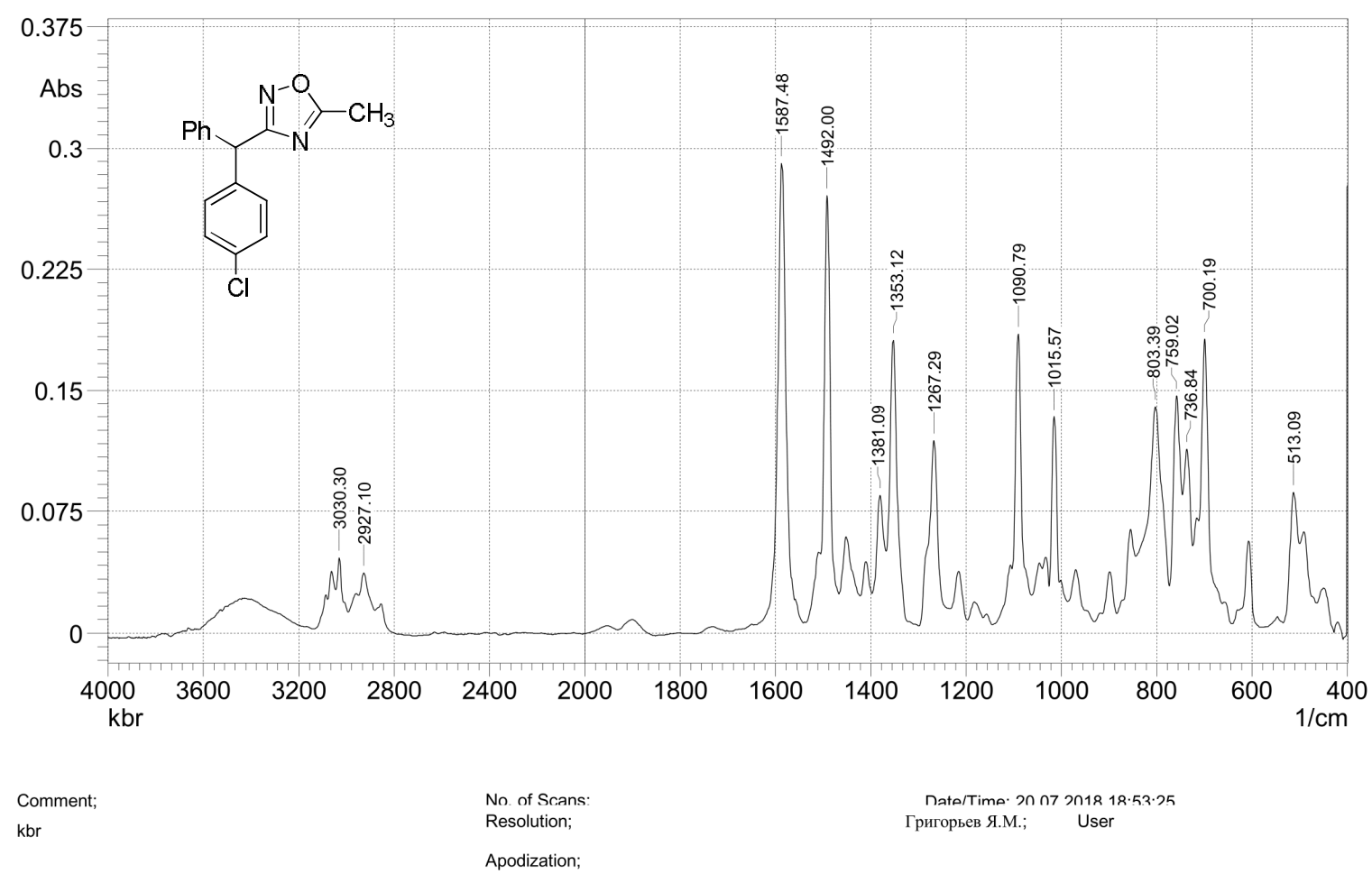

Fig. S77. IR spectrum of the compound $2 \mathbf{y}(\mathrm{KBr})$.
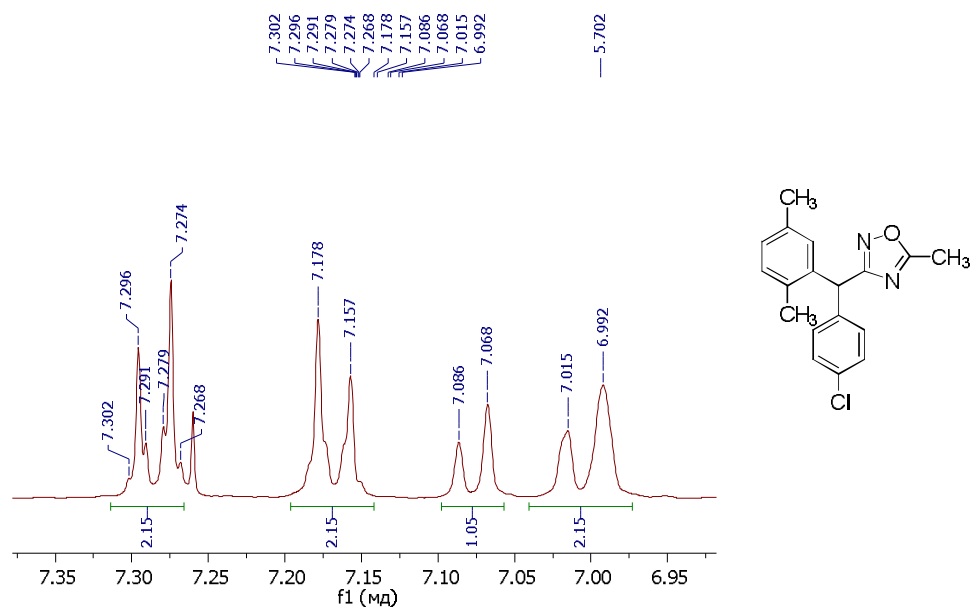

^

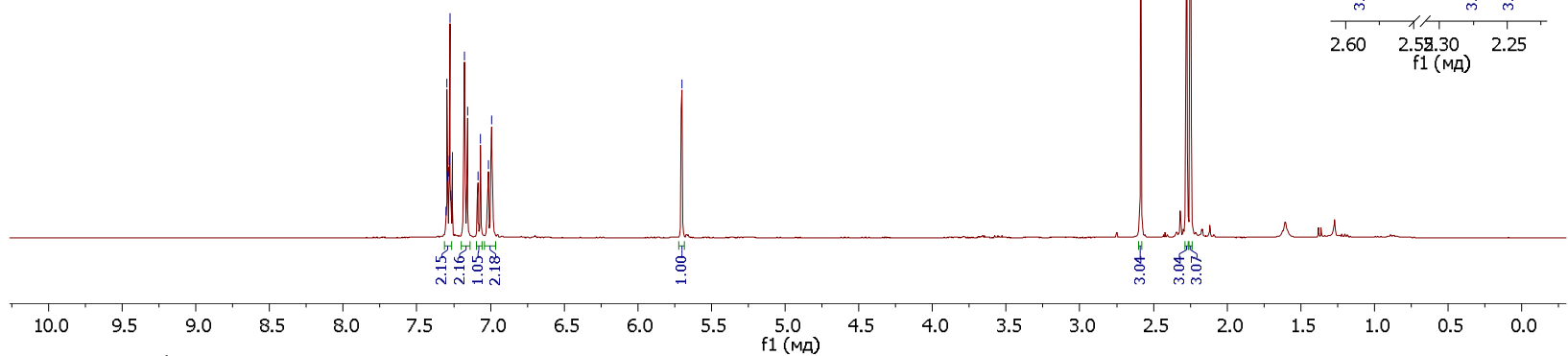

Fig. S78. ${ }^{1} \mathrm{H}$ NMR spectrum of the compound $\mathbf{2 z}\left(\mathrm{CDCl}_{3}, 400 \mathrm{MHz}\right)$. 


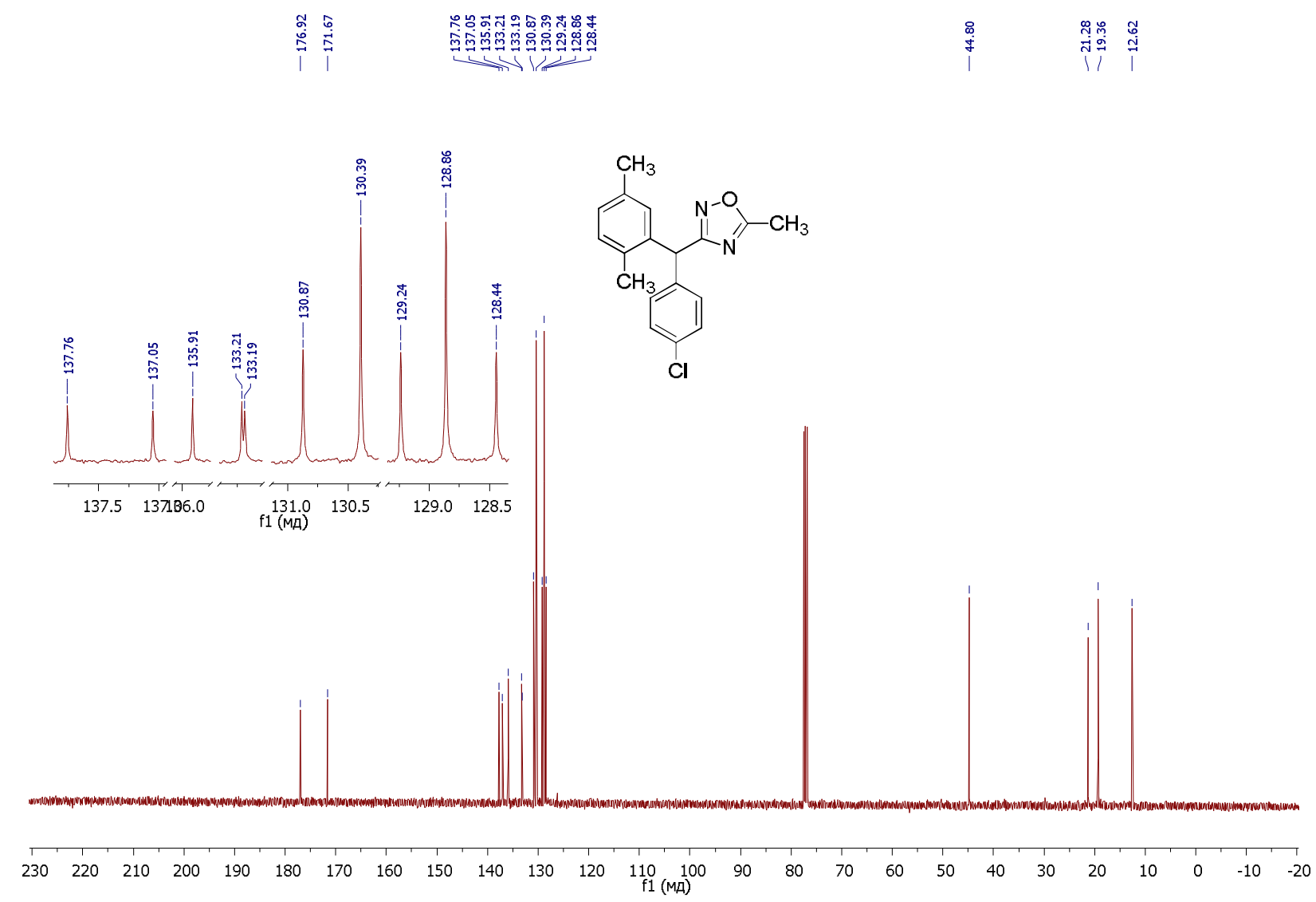

Fig. S79. ${ }^{13} \mathrm{C}\{\mathrm{H}\}$ NMR spectrum of the compound $\mathbf{2 z}\left(\mathrm{CDCl}_{3}, 101 \mathrm{MHz}\right)$.

๑ SHIMADZU

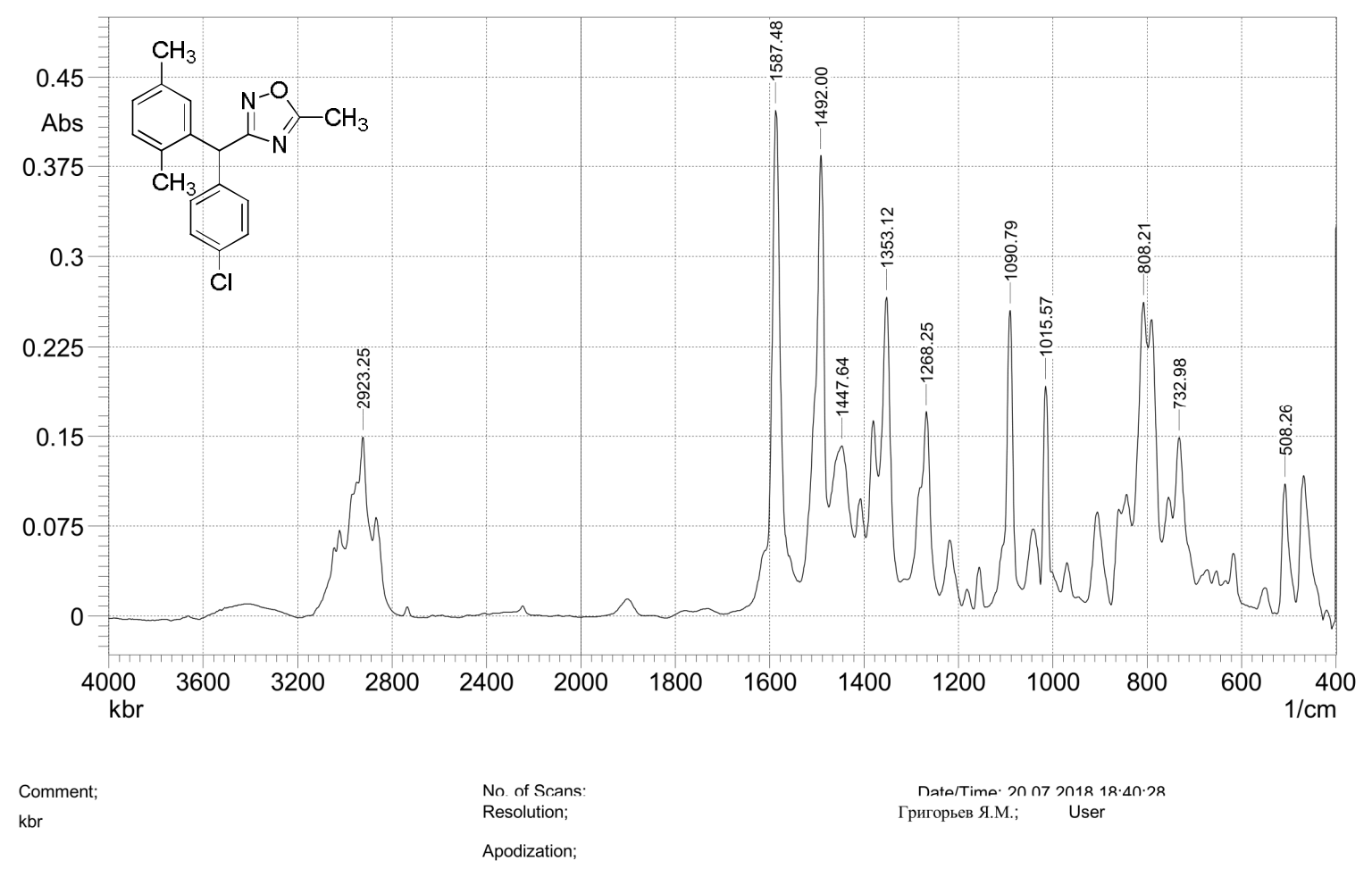

Fig. S80. IR spectrum of the compound $\mathbf{2 z}(\mathrm{KBr})$. 

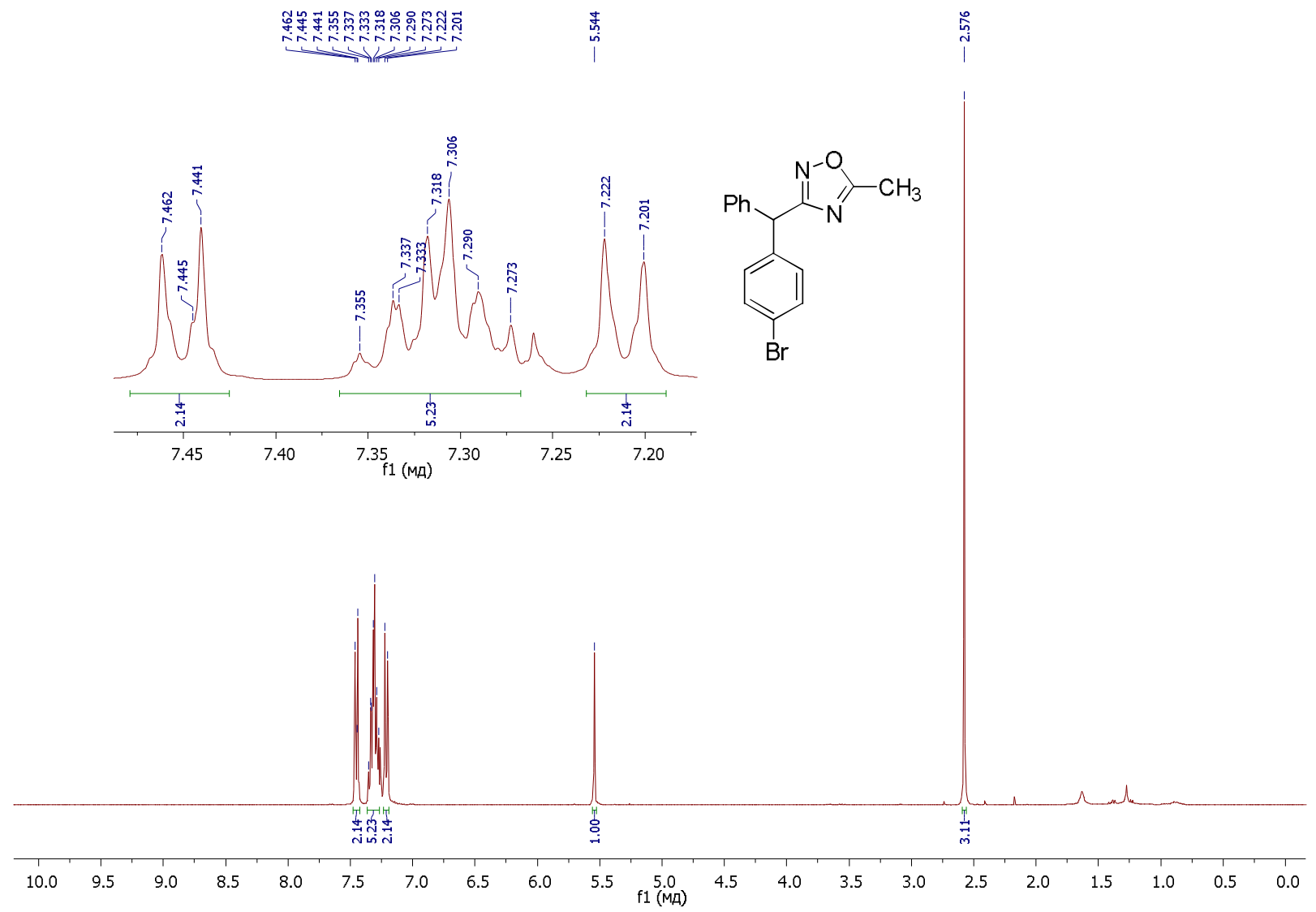

Fig. S81. ${ }^{1} \mathrm{H}$ NMR spectrum of the compound $\mathbf{2 z a}\left(\mathrm{CDCl}_{3}, 400 \mathrm{MHz}\right)$.

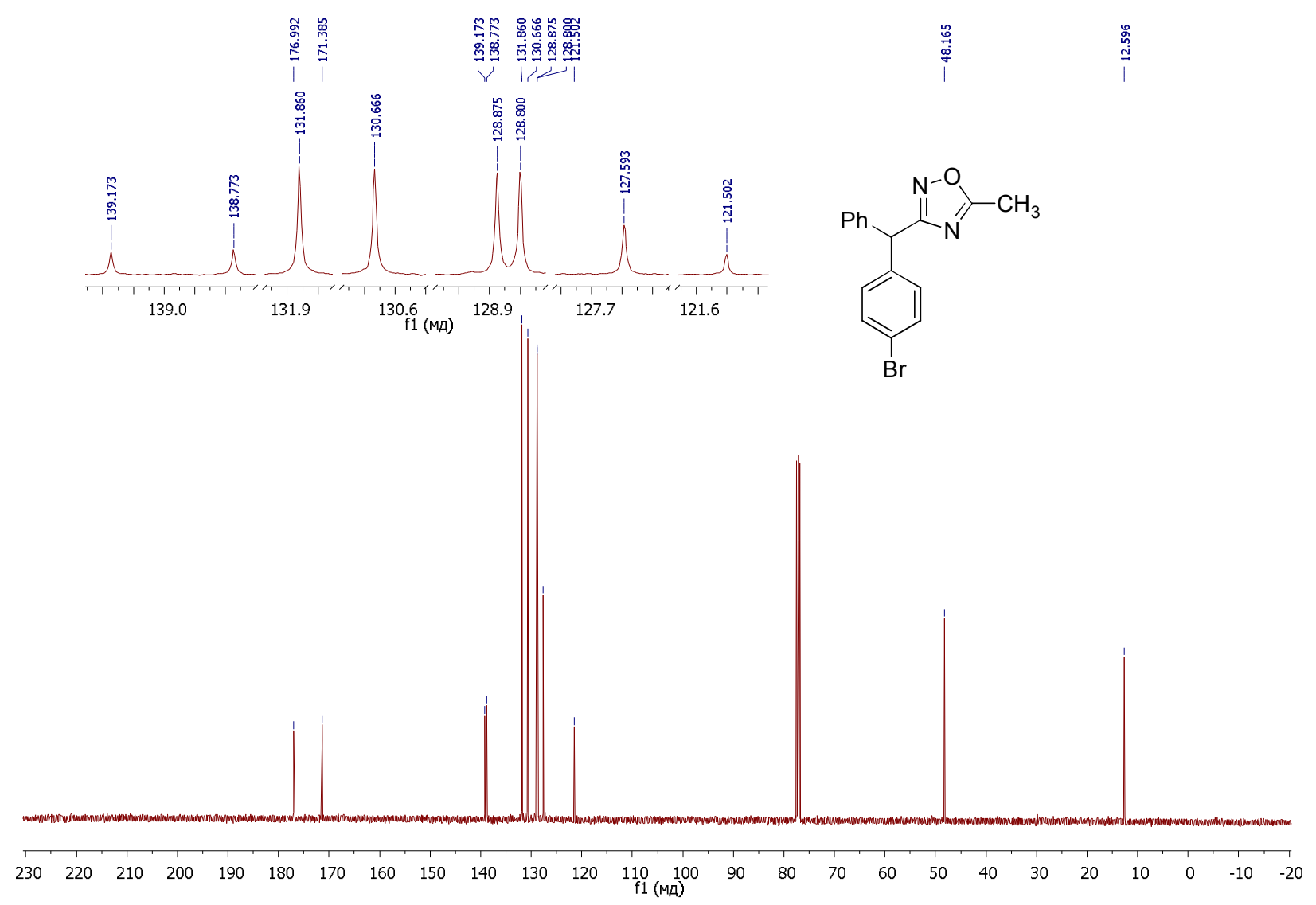

Fig. S82. ${ }^{13} \mathrm{C}\{\mathrm{H}\}$ NMR spectrum of the compound $\mathbf{2 z a}\left(\mathrm{CDCl}_{3}, 101 \mathrm{MHz}\right)$. 


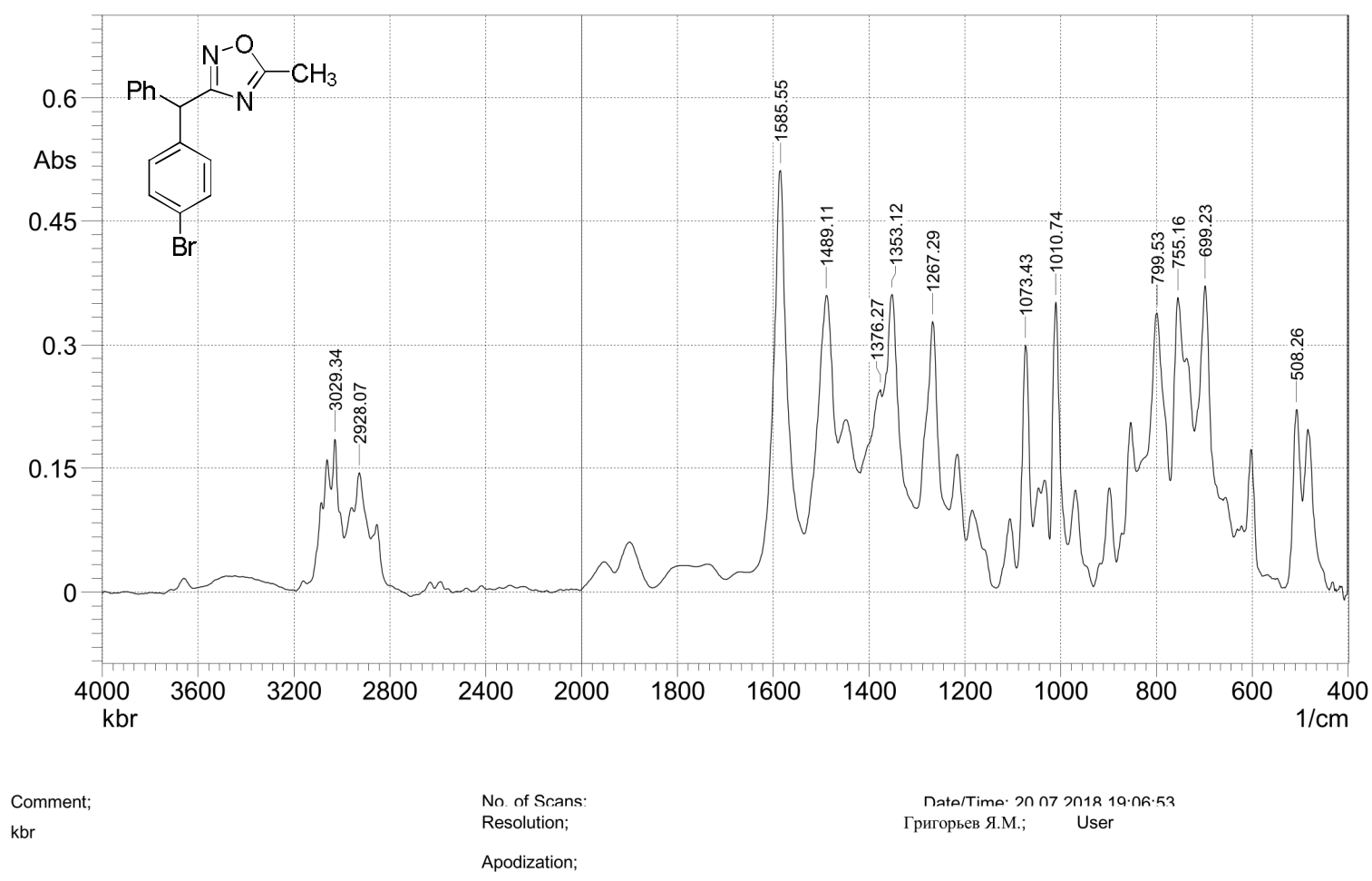

Fig. S83. IR spectrum of the compound $\mathbf{2 z a}(\mathrm{KBr})$.
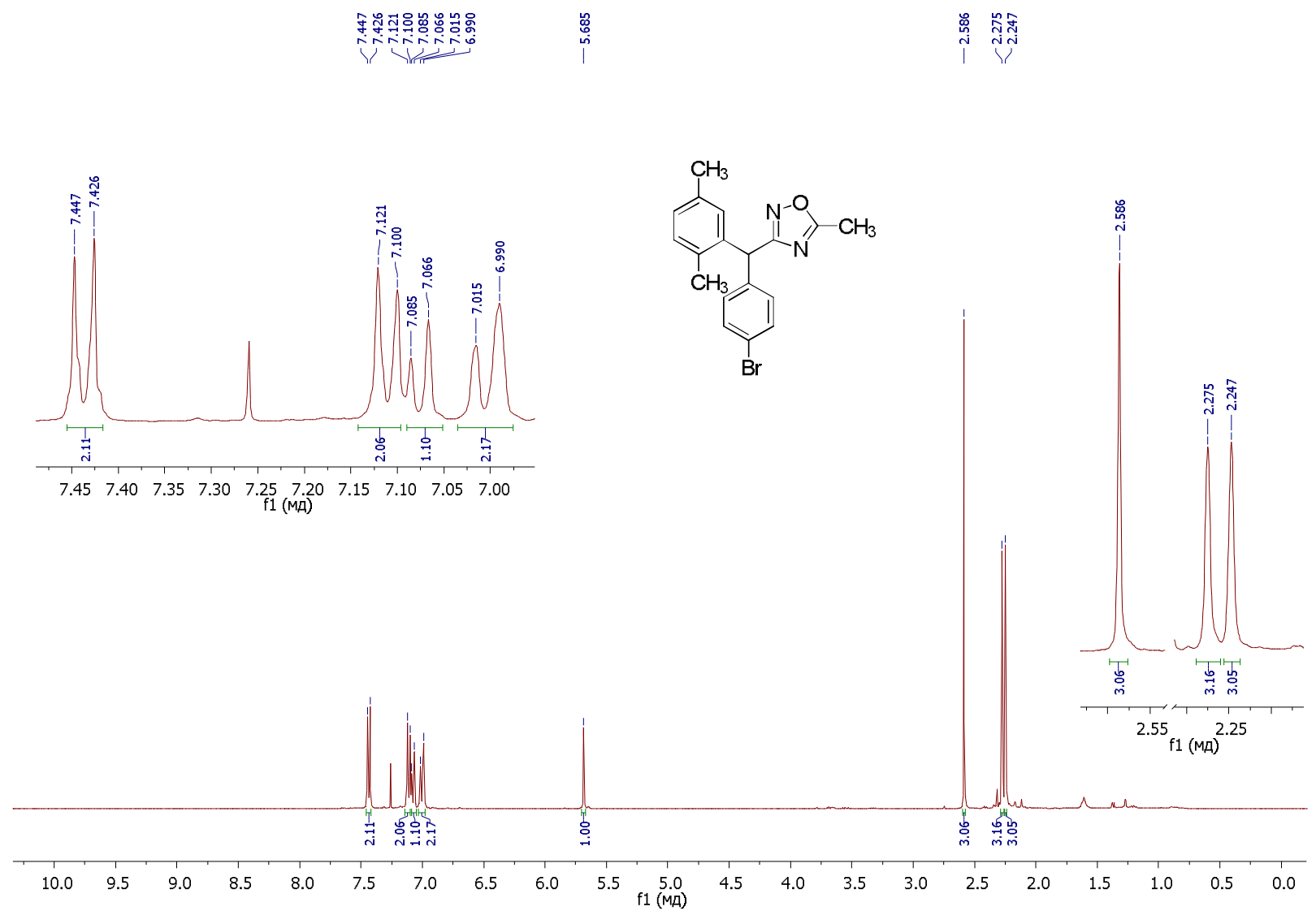

Fig. S84. ${ }^{1} \mathrm{H}$ NMR spectrum of the compound $\mathbf{2 z b}\left(\mathrm{CDCl}_{3}, 400 \mathrm{MHz}\right)$. 


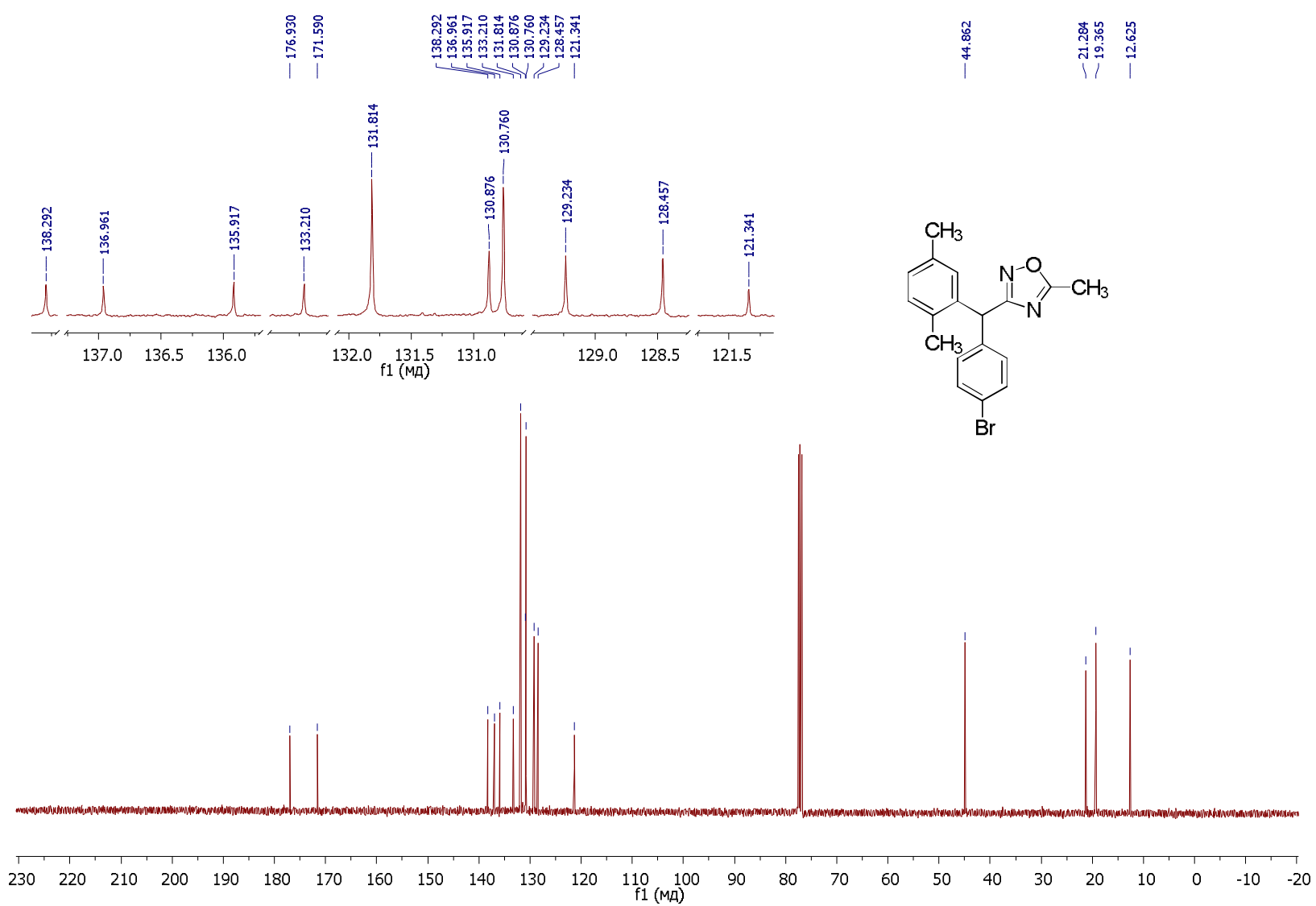

Fig. S85. ${ }^{13} \mathrm{C}\{\mathrm{H}\}$ NMR spectrum of the compound $\mathbf{2 z b}\left(\mathrm{CDCl}_{3}, 101 \mathrm{MHz}\right)$.

๑SHIMADZU

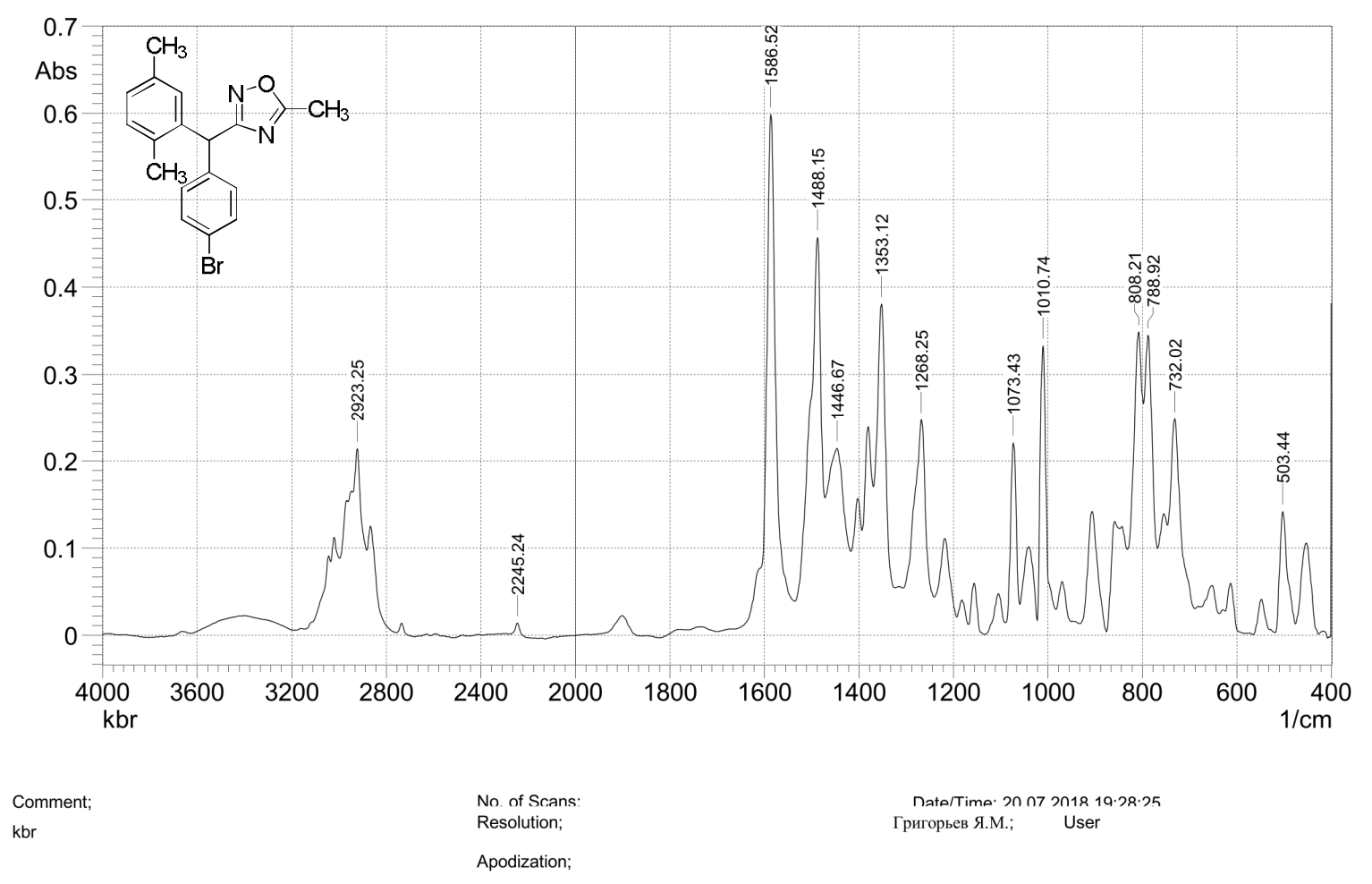

Fig. S86. IR spectrum of the compound 2zb (KBr). 


\section{X-ray data for compounds $2 i, n, 0, x$}

$2 \mathbf{i}$

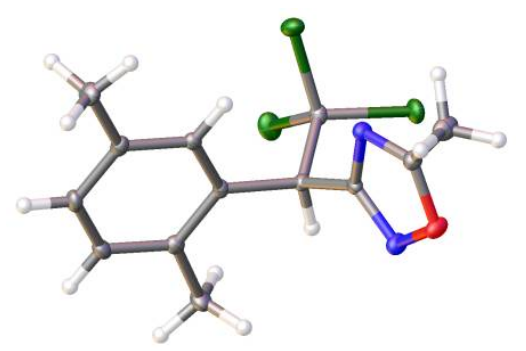

Fig. S86. Molecular structure of 2i, CCDC 1888351 (ellipsoid contour of probability levels is 50 $\%)$.

Table S1 Crystal data and structure refinement for $2 i$.

Identificationcode

$2 \mathrm{i}$

Empiricalformula

$\mathrm{C}_{13} \mathrm{H}_{13} \mathrm{Cl}_{3} \mathrm{~N}_{2} \mathrm{O}$

Formulaweight

319.60

Temperature/K

100(2)

Crystalsystem

monoclinic

Spacegroup

$\mathrm{P} 21 / \mathrm{n}$

$\mathrm{a} / \AA$

11.1472(3)

$\mathrm{b} / \AA$

$8.8578(2)$

$\mathrm{c} / \AA$

$14.7757(4)$

$\alpha /{ }^{\circ}$

90

$\beta /{ }^{\circ}$

$\gamma /{ }^{\circ}$

101.894(3)

Volume $/ \AA^{3}$

90

Z

1427.63(7)

$\rho_{\text {calc }} \mathrm{g} / \mathrm{cm}^{3}$

4

$\mu / \mathrm{mm}^{-1}$

1.487

0.634

$\mathrm{F}(000)$

656.0

Crystalsize $/ \mathrm{mm}^{3}$

$0.52 \times 0.5 \times 0.42$

Radiation

$\operatorname{MoK} \alpha(\lambda=0.71073)$

$2 \Theta$ range for data collection $/{ }^{\circ} 5.12$ to 61.632

Indexranges

$-8 \leq \mathrm{h} \leq 15,-11 \leq \mathrm{k} \leq 12,-21 \leq 1 \leq 18$

Reflectionscollected

7311

Independentreflections

Data/restraints/parameters

$3993\left[\mathrm{R}_{\text {int }}=0.0238, \mathrm{R}_{\text {sigma }}=0.0397\right]$

$3993 / 0 / 175$

Goodness-of-fit on $\mathrm{F}^{2}$

1.052

Final $\mathrm{R}$ indexes $[\mathrm{I}>=2 \sigma(\mathrm{I})] \quad \mathrm{R}_{1}=0.0325, \mathrm{wR}_{2}=0.0686$

Final $\mathrm{R}$ indexes [all data] $\quad \mathrm{R}_{1}=0.0426, \mathrm{wR}_{2}=0.0733$

Largest diff. peak/hole / e $\AA^{-3} 0.39 /-0.30$ 


\section{Experimental}

Single crystals of $\mathrm{C}_{13} \mathrm{H}_{13} \mathrm{Cl}_{3} \mathrm{~N}_{2} \mathrm{O} 2 \mathbf{i}$ were obtained at slow evaporation of solution of $2 \mathbf{i}$ in diethyl ether. A suitable crystal was selected and studied on a Xcalibur, Eos diffractometer. The crystal was kept at 100(2) K during data collection. Using Olex2 [1], the structure was solved with the Superflip [2] structure solution program using Charge Flipping and refined with the ShelXL [3] refinement package using Least Squares minimisation.

1. Dolomanov, O.V., Bourhis, L.J., Gildea, R.J, Howard, J.A.K. \&Puschmann, H. (2009), J. Appl. Cryst. 42, 339-341.

2. Palatinus, L. \&Chapuis, G. (2007). J. Appl. Cryst., 40, 786-790; Palatinus, L. \& van der Lee, A. (2008). J. Appl. Cryst. 41, 975-984; Palatinus, L., Prathapa, S. J. \& van Smaalen, S. (2012). J. Appl. Cryst. 45, 575580.

3. Sheldrick, G.M. (2015). ActaCryst. C71, 3-8.

\section{Crystal structure determination of $2 \mathbf{i}$}

Crystal Data for $\mathrm{C}_{13} \mathrm{H}_{13} \mathrm{Cl}_{3} \mathrm{~N}_{2} \mathrm{O} \quad(M=319.60 \mathrm{~g} / \mathrm{mol})$ : monoclinic, space group $\mathrm{P} 2 / \mathrm{n}$ (no. 14), $a=$ $11.1472(3) \AA, b=8.8578(2) \AA, c=14.7757(4) \AA, \beta=101.894(3)^{\circ}, V=1427.63(7) \AA^{3}, Z=4, T=100(2) \mathrm{K}$, $\mu(\mathrm{MoK} \alpha)=0.634 \mathrm{~mm}^{-1}$, Dcalc $=1.487 \mathrm{~g} / \mathrm{cm}^{3}, 7311$ reflections measured $\left(5.12^{\circ} \leq 2 \Theta \leq 61.632^{\circ}\right), 3993$ unique $\left(R_{\text {int }}=0.0238, R_{\text {sigma }}=0.0397\right)$ which were used in all calculations. The final $R_{1}$ was $0.0325(\mathrm{I}>2 \sigma(\mathrm{I}))$ and $w R_{2}$ was 0.0733 (all data).

\section{Refinement model description}

Details:

Number of restraints - 0 , number of constraints - unknown.

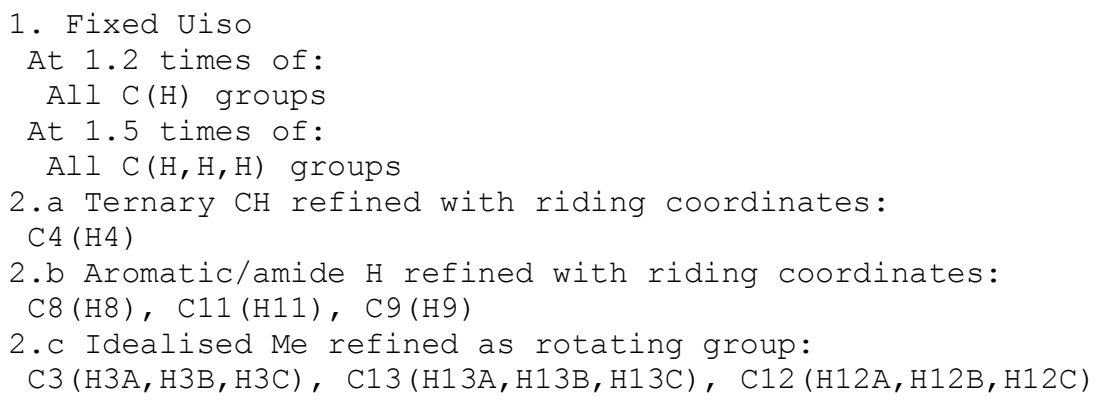

$2 n$

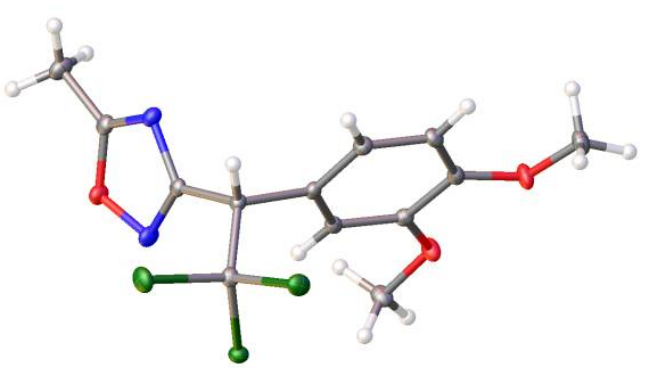

Fig. S87. Molecular structure of 2n, CCDC 1894770 (ellipsoid contour of probability levels is 50 $\%)$.

Table S2 Crystal data and structure refinement for $\mathbf{2 n}$.

$\begin{array}{ll}\text { Identificationcode } & 2 \mathrm{n} \\ \text { Empiricalformula } & \mathrm{C}_{13} \mathrm{H}_{13} \mathrm{Cl}_{3} \mathrm{~N}_{2} \mathrm{O}_{3} \\ \text { Formulaweight } & 351.60 \\ \text { Temperature/K } & 100.01(10) \\ \text { Crystalsystem } & \text { triclinic } \\ \text { Spacegroup } & \mathrm{P}-1 \\ \mathrm{a} / \AA & 8.5663(4) \\ \mathrm{b} / \AA & 9.2482(4)\end{array}$




$\begin{array}{ll}\mathrm{c} / \AA & 10.8111(5) \\ \alpha /{ }^{\circ} & 105.441(4) \\ \beta /{ }^{\circ} & 113.046(4) \\ \gamma /{ }^{\circ} & 97.005(4) \\ \text { Volume/ } \AA^{3} & 734.58(6) \\ \mathrm{Z} & 2 \\ \rho_{\text {calcg }} / \mathrm{cm}^{3} & 1.590 \\ \mu / \mathrm{mm}^{-1} & 0.634 \\ \mathrm{~F}(000) & 360.0 \\ \text { Crystalsize/mm } & \\ \text { Radiation } & 0.5 \times 0.34 \times 0.26 \\ 2 \Theta \text { range for data collection/ } & { }^{3} 5.214 \text { to } 55 \\ \text { Indexranges } & -11 \leq \mathrm{h} \leq 11,-12 \leq \mathrm{k} \leq 12,-14 \leq 1 \leq 14 \\ \text { Reflectionscollected } & 12653 \\ \text { Independentreflections } & 3353\left[\mathrm{R}_{\text {int }}=0.0179, \mathrm{R}_{\text {sigma }}=0.0161\right] \\ \text { Data/restraints/parameters } & 3353 / 0 / 193 \\ \text { Goodness-of-fit on } \mathrm{F}^{2} & 1.070 \\ \text { Final R indexes }[\mathrm{I}>=2 \sigma(\mathrm{I})] & \mathrm{R}_{1}=0.0232, \mathrm{wR}_{2}=0.0540 \\ \text { Final R indexes [all data }] & \mathrm{R}_{1}=0.0255, \mathrm{wR}_{2}=0.0553 \\ \text { Largest diff. peak/hole } / \mathrm{e} \AA^{-3} 0.41 /-0.20\end{array}$

\section{Experimental}

Single crystals of $\mathrm{C}_{13} \mathrm{H}_{13} \mathrm{Cl}_{3} \mathrm{~N}_{2} \mathrm{O}_{3} \mathbf{2 n}$ were obtained at slow evaporation of solution of $\mathbf{2 n}$ in diethyl ether. A suitable crystal was selected and studied on a Xcalibur, Eos diffractometer. The crystal was kept at 100.01(10) K during data collection. Using Olex2 [1], the structure was solved with the Superflip [2] structure solution program using Charge Flipping and refined with the ShelXL [3] refinement package using Least Squares minimisation.

1. Dolomanov, O.V., Bourhis, L.J., Gildea, R.J, Howard, J.A.K. \&Puschmann, H. (2009), J. Appl. Cryst. 42, 339-341.

2. Palatinus, L. \&Chapuis, G. (2007). J. Appl. Cryst., 40, 786-790; Palatinus, L. \& van der Lee, A. (2008). J. Appl. Cryst. 41, 975-984; Palatinus, L., Prathapa, S. J. \& van Smaalen, S. (2012). J. Appl. Cryst. 45, 575580.

3. Sheldrick, G.M. (2015). ActaCryst. C71, 3-8.

\section{Crystal structure determination of $2 \mathrm{n}$}

Crystal Data for $\mathrm{C}_{13} \mathrm{H}_{13} \mathrm{Cl}_{3} \mathrm{~N}_{2} \mathrm{O}_{3}(M=351.60 \mathrm{~g} / \mathrm{mol})$ : triclinic, space group P-1 (no. 2), $a=8.5663$ (4) $\AA, b=$ 9.2482(4) $\AA, c=10.8111(5) \AA, \alpha=105.441(4)^{\circ}, \beta=113.046(4)^{\circ}, \gamma=97.005(4)^{\circ}, V=734.58(6) \AA^{3}, Z=2, T=$ $100.01(10) \mathrm{K}, \mu(\mathrm{MoK} \alpha)=0.634 \mathrm{~mm}^{-1}$, Dcalc $=1.590 \mathrm{~g} / \mathrm{cm}^{3}, 12653$ reflections measured $\left(5.214^{\circ} \leq 2 \Theta \leq 55^{\circ}\right), 3353$ unique $\left(R_{\text {int }}=0.0179, R_{\text {sigma }}=0.0161\right)$ which were used in all calculations. The final $R_{1}$ was $0.0232(\mathrm{I}>2 \sigma(\mathrm{I}))$ and $w R_{2}$ was 0.0553 (all data).

\section{Refinement model description}

Number of restraints - 0 , number of constraints - unknown.

Details:

1. Fixed Uiso

At 1.2 times of:

All $\mathrm{C}(\mathrm{H})$ groups

At 1.5 times of:

All $\mathrm{C}(\mathrm{H}, \mathrm{H}, \mathrm{H})$ groups

2.a Ternary $\mathrm{CH}$ refined with riding coordinates:

$\mathrm{C} 10(\mathrm{H} 10)$

2.b Aromatic/amide $\mathrm{H}$ refined with riding coordinates:

$\mathrm{C} 4(\mathrm{H} 4), \mathrm{C} 7(\mathrm{H} 7), \mathrm{C} 8(\mathrm{H} 8)$ 


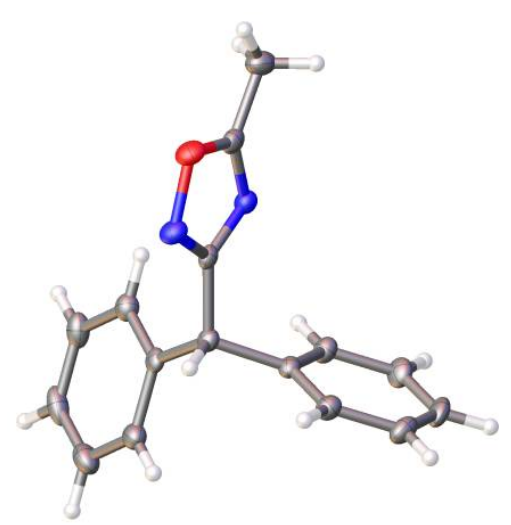

Fig. S88. Molecular structure of 2o, CCDC 1894769 (ellipsoid contour of probability levels is 50 $\%)$.

Table S3 Crystal data and structure refinement for 20.

Identificationcode

20

Empiricalformula

$\mathrm{C}_{16} \mathrm{H}_{14} \mathrm{~N}_{2} \mathrm{O}$

Formulaweight

250.29

Temperature/K

100(2)

Crystalsystem

monoclinic

Spacegroup

$\mathrm{P} 2{ }_{1} / \mathrm{c}$

$\mathrm{a} / \AA \AA$

12.8072(7)

$\mathrm{b} / \AA$

$6.0525(4)$

$\mathrm{c} / \AA$

$\alpha /{ }^{\circ}$

$16.8346(9)$

$\beta /{ }^{\circ}$

90

$\gamma /{ }^{\circ}$

91.053(5)

Volume $/ \AA^{3}$

90

Z

$1304.72(13)$

$\rho_{\text {calc }} \mathrm{g} / \mathrm{cm}^{3}$

4

$\mu / \mathrm{mm}^{-1}$

1.274

0.643

$\mathrm{F}(000)$

528.0

Crystalsize $/ \mathrm{mm}^{3}$

$0.59 \times 0.5 \times 0.49$

Radiation

$\mathrm{CuK} \alpha(\lambda=1.54184)$

$2 \Theta$ range for data collection $/{ }^{\circ} 6.904$ to 152.282

Indexranges

Reflectionscollected

$-15 \leq \mathrm{h} \leq 15,-7 \leq \mathrm{k} \leq 6,-20 \leq 1 \leq 19$

Independentreflections

4425

Data/restraints/parameters

$2516\left[\mathrm{R}_{\text {int }}=0.0230, \mathrm{R}_{\text {sigma }}=0.0242\right]$

Goodness-of-fit on $\mathrm{F}^{2}$

$2516 / 0 / 173$

Final $R$ indexes $[\mathrm{I}>=2 \sigma(\mathrm{I})] \quad \mathrm{R}_{1}=0.0428, \mathrm{wR}_{2}=0.1110$

Final $\mathrm{R}$ indexes [all data] $\quad \mathrm{R}_{1}=0.0466, \mathrm{wR}_{2}=0.1147$

Largest diff. peak/hole / e $\AA^{-3} 0.23 /-0.25$ 


\section{Experimental}

Single crystals of $\mathrm{C}_{16} \mathrm{H}_{14} \mathrm{~N}_{2} \mathrm{O} 2 \mathrm{o}$ were obtained at slow evaporation of solution of $2 \mathrm{o}$ in diethyl ether. A suitable crystal was selected and studied on a Xcalibur, Eos diffractometer.The crystal was kept at 100(2) K during data collection. Using Olex2 [1], the structure was solved with the Unknown [2] structure solution program using Unknown and refined with the Unknown [3] refinement package using Unknown minimisation.

1. Dolomanov, O.V., Bourhis, L.J., Gildea, R.J, Howard, J.A.K. \&Puschmann, H. (2009), J. Appl. Cryst. 42, 339-341.

2. Palatinus, L. \&Chapuis, G. (2007). J. Appl. Cryst., 40, 786-790; Palatinus, L. \& van der Lee, A. (2008). J. Appl. Cryst. 41, 975-984; Palatinus, L., Prathapa, S. J. \& van Smaalen, S. (2012). J. Appl. Cryst. 45, 575580 .

3. Sheldrick, G.M. (2015). ActaCryst. C71, 3-8.

\section{Crystal structure determination of 20}

Crystal Data for $\mathrm{C}_{16} \mathrm{H}_{14} \mathrm{~N}_{2} \mathrm{O} \quad(M=250.29 \mathrm{~g} / \mathrm{mol})$ : monoclinic, space group $\mathrm{P} 2_{1} / \mathrm{c}$ (no. 14), $a=$ 12.8072(7) $\AA, b=6.0525(4) \AA, c=16.8346(9) \AA, \beta=91.053(5)^{\circ}, V=1304.72(13) \AA^{3}, Z=4, T=100(2) \mathrm{K}$, $\mu(\mathrm{CuK} \alpha)=0.643 \mathrm{~mm}^{-1}$, Dcalc $=1.274 \mathrm{~g} / \mathrm{cm}^{3}, 4425$ reflections measured $\left(6.904^{\circ} \leq 2 \Theta \leq 152.282^{\circ}\right), 2516$ unique $\left(R_{\text {int }}=0.0230, R_{\text {sigma }}=0.0242\right)$ which were used in all calculations. The final $R_{1}$ was $0.0428(\mathrm{I}>2 \sigma(\mathrm{I}))$ and $w R_{2}$ was 0.1147 (all data).

\section{Refinement model description}

Details:

Number of restraints - 0 , number of constraints - unknown.

1. Fixed Uiso

At 1.2 times of:

All $\mathrm{C}(\mathrm{H})$ groups

At 1.5 times of:

All $\mathrm{C}(\mathrm{H}, \mathrm{H}, \mathrm{H})$ groups

2.a Ternary $\mathrm{CH}$ refined with riding coordinates:

$\mathrm{C} 3(\mathrm{H} 3)$

2.b Aromatic/amide $\mathrm{H}$ refined with riding coordinates:

C6(H6), C16(H16), C10(H10), C12(H12), C7(H7), C8(H8), C15(H15), C9(H9),

C13(H13), C14(H14)

2.c Idealised Me refined as rotating group:

$\mathrm{C} 4(\mathrm{H} 4 \mathrm{~A}, \mathrm{H} 4 \mathrm{~B}, \mathrm{H} 4 \mathrm{C})$

A suitable crystal was selected and studied on a Xcalibur, Eos diffractometer.

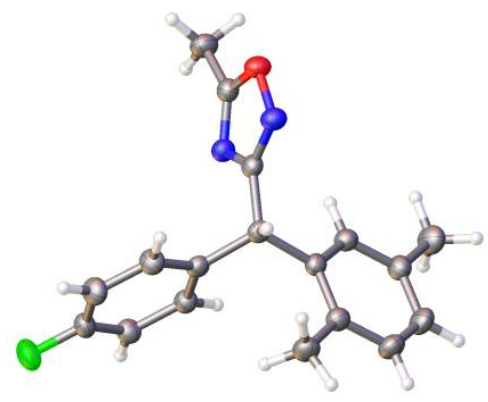

Fig. S90. Molecular structure of 2x, CCDC 1894768 (ellipsoid contour of probability levels is 50 $\%)$.

Table S4 Crystal data and structure refinement for $2 x$.

Identificationcode

Empiricalformula

$2 \mathrm{x}$

$\mathrm{C}_{18} \mathrm{H}_{17} \mathrm{FN}_{2} \mathrm{O}$ 


\begin{tabular}{|c|c|}
\hline Formulaweight & 296.33 \\
\hline Temperature/K & $114(2)$ \\
\hline Crystalsystem & triclinic \\
\hline Spacegroup & $\mathrm{P}-1$ \\
\hline $\mathrm{a} / \AA$ & $7.5047(3)$ \\
\hline $\mathrm{b} / \AA \AA$ & $9.2211(4)$ \\
\hline $\mathrm{c} / \AA ̊$ & $11.4499(6)$ \\
\hline$\alpha /{ }^{\circ}$ & $90.884(4)$ \\
\hline$\beta /{ }^{\circ}$ & $103.956(4)$ \\
\hline$\gamma /{ }^{\circ}$ & $95.264(4)$ \\
\hline Volume/ $\AA^{3}$ & $765.14(6)$ \\
\hline $\mathrm{Z}$ & 2 \\
\hline$\rho_{\text {calc }} \mathrm{g} / \mathrm{cm}^{3}$ & 1.286 \\
\hline$\mu / \mathrm{mm}^{-1}$ & 0.726 \\
\hline $\mathrm{F}(000)$ & 312.0 \\
\hline Crystalsize $/ \mathrm{mm}^{3}$ & $0.17 \times 0.12 \times 0.1$ \\
\hline Radiation & $\operatorname{CuK} \alpha(\lambda=1.54184)$ \\
\hline \multicolumn{2}{|c|}{$2 \Theta$ range for data collection $/{ }^{\circ} 7.962$ to 145.04} \\
\hline Indexranges & $-9 \leq \mathrm{h} \leq 9,-10 \leq \mathrm{k} \leq 11,-14 \leq 1 \leq 14$ \\
\hline Reflectionscollected & 9305 \\
\hline Independentreflections & $2990\left[\mathrm{R}_{\mathrm{int}}=0.0292, \mathrm{R}_{\mathrm{sigma}}=0.0312\right]$ \\
\hline Data/restraints/parameters & $2990 / 0 / 202$ \\
\hline Goodness-of-fit on $\mathrm{F}^{2}$ & 1.071 \\
\hline Final $R$ indexes $[I>=2 \sigma(I)]$ & $\mathrm{R}_{1}=0.0411, \mathrm{wR}_{2}=0.1097$ \\
\hline Final R indexes [all data] & $\mathrm{R}_{1}=0.0497, \mathrm{wR}_{2}=0.1156$ \\
\hline \multicolumn{2}{|c|}{ Largest diff. peak/hole / e $\AA^{-3} 0.23 /-0.26$} \\
\hline
\end{tabular}

Single crystals of $\mathrm{C}_{18} \mathrm{H}_{17} \mathrm{FN}_{2} \mathrm{O} 2 \mathbf{x}$ were obtained at slow evaporation of solution of $2 \mathrm{x}$ in diethyl ether. A suitable crystal was selected and studied on a SuperNova, Single source at offset/far, HyPix3000 diffractometer. The crystal was kept at 114(2) K during data collection. Using Olex2 [1], the structure was solved with the ShelXT [2] structure solution program using Intrinsic Phasing and refined with the ShelXL [3] refinement package using Least Squares minimisation.

1. Dolomanov, O.V., Bourhis, L.J., Gildea, R.J, Howard, J.A.K. \&Puschmann, H. (2009), J. Appl. Cryst. 42 , 339-341.

2. Sheldrick, G.M. (2015). ActaCryst. A71, 3-8.

3. Sheldrick, G.M. (2015). ActaCryst. C71, 3-8.

Crystal structure determination of $2 \mathrm{x}$.

Crystal Data for $\mathrm{C}_{18} \mathrm{H}_{17} \mathrm{FN}_{2} \mathrm{O}(M=296.33 \mathrm{~g} / \mathrm{mol})$ : triclinic, space group P-1 (no. 2), $a=7.5047(3) \AA, b=$ 9.2211(4) $\AA, c=11.4499(6) \AA, \alpha=90.884(4)^{\circ}, \beta=103.956(4)^{\circ}, \gamma=95.264(4)^{\circ}, V=765.14(6) \AA^{3}, Z=2, T=$ $114(2) \mathrm{K}, \mu(\mathrm{CuK} \alpha)=0.726 \mathrm{~mm}^{-1}$, Dcalc $=1.286 \mathrm{~g} / \mathrm{cm}^{3}, 9305$ reflections measured $\left(7.962^{\circ} \leq 2 \Theta \leq 145.04^{\circ}\right), 2990$ unique $\left(R_{\text {int }}=0.0292, \mathrm{R}_{\text {sigma }}=0.0312\right)$ which were used in all calculations. The final $R_{1}$ was 0.0411 (I $\left.>2 \sigma(\mathrm{I})\right)$ and $w R_{2}$ was 0.1156 (all data).

\section{Refinement model description}

Details:

Number of restraints - 0 , number of constraints - unknown.

1. Fixed Uiso

At 1.2 times of:

All $\mathrm{C}(\mathrm{H})$ groups

At 1.5 times of:

All $\mathrm{C}(\mathrm{H}, \mathrm{H}, \mathrm{H})$ groups

2.a Ternary $\mathrm{CH}$ refined with riding coordinates:

$\mathrm{C} 4(\mathrm{H} 4)$

2.b Aromatic/amide $\mathrm{H}$ refined with riding coordinates:

C7(H7), C6(H6), C12(H12), C10(H10), C9(H9), C15(H15), C14(H14)

2.c Idealised Me refined as rotating group:

C18(H18A,H18B,H18C), C3(H3A,H3B,H3C), C17(H17A,H17B,H17C) 